Portland State University

PDXScholar

$5-1-1970$

\title{
Mobility of physicians into prepaid group health practice; a case study
}

Ann Schroeder Sato

Portland State University

Follow this and additional works at: https://pdxscholar.library.pdx.edu/open_access_etds Let us know how access to this document benefits you.

\section{Recommended Citation}

Sato, Ann Schroeder, "Mobility of physicians into prepaid group health practice; a case study" (1970). Dissertations and Theses. Paper 107.

https://doi.org/10.15760/etd.107

This Thesis is brought to you for free and open access. It has been accepted for inclusion in Dissertations and Theses by an authorized administrator of PDXScholar. Please contact us if we can make this document more accessible: pdxscholar@pdx.edu. 


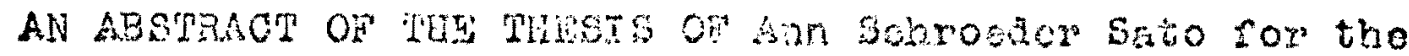
Master or Arts in Socibogy presentud hay 1, 1.970.

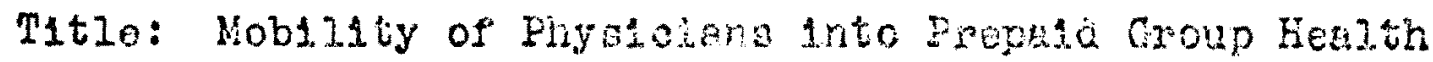
Practjce: $\Lambda$ Vase Stuay.

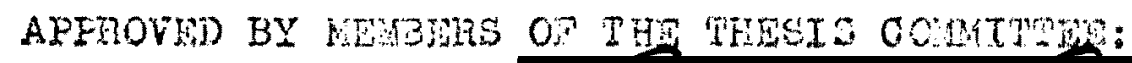

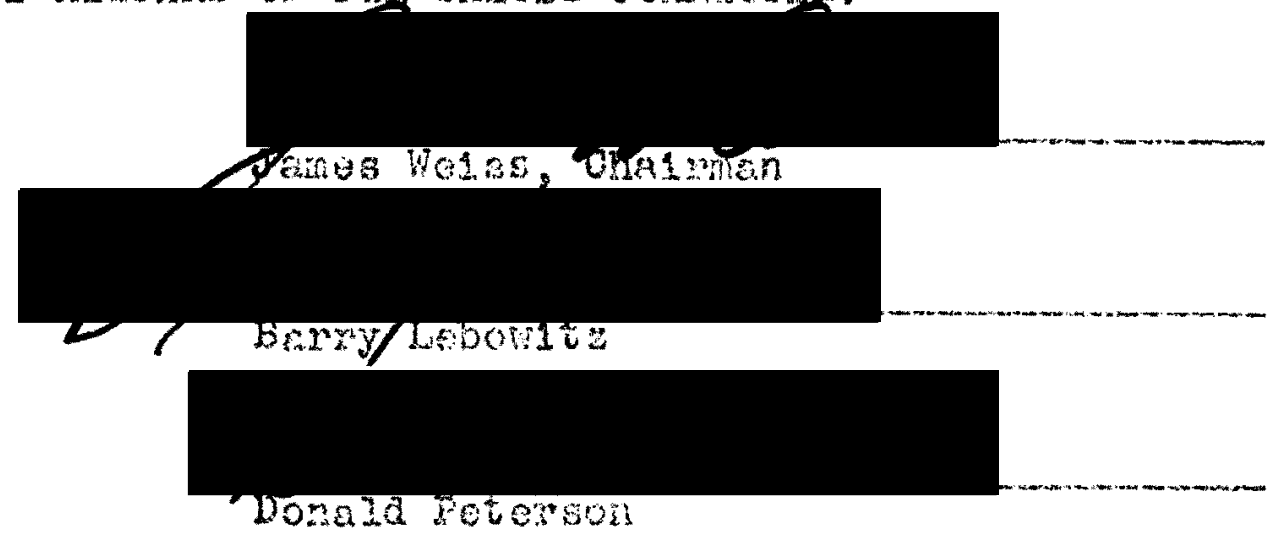

Thie thend is concerned whth chinges ovex thite in the socis characteristes of dootore who have entered propaid growp boath plans. It fouses on the paet sockal poations whoh theas aoctors have oocupled end on thedr status, or rent. The genorel expestation is that both the rank and the poustons cooupted by dootore prior to enteung provald

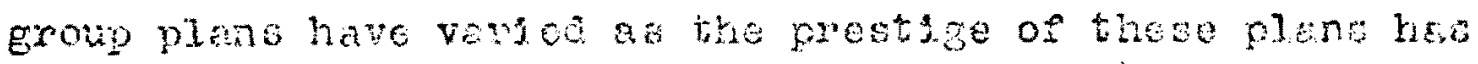
vasied.

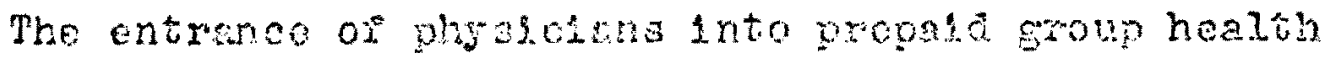

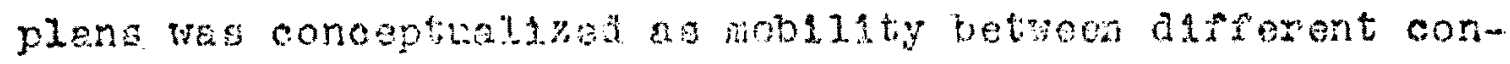

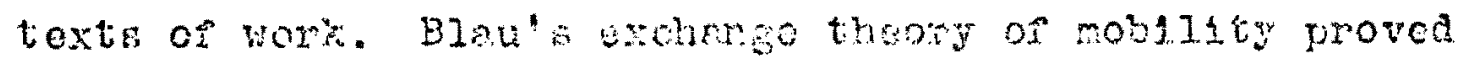


to be the most fruitful sourco of bypotheses for this stuoy. Blau states that extringlc rewards axe the major incentives for mobility and that intringie rovarde interact with extrinsio revards in influencing mobility. From these basic propositiona two bypotheses were generated: 1) Ag tho status of prepald group health plans 1ncreases, the status of physlcians entering these plane will increaso. 2) As the status of prepald group health plans 1noreaces, high status reorulto w111 less frequentiy come from postions offering Intrinsic rewards similar to those found in prepald sroup plans.

The design of this research was a longltudirial case study. Data were obtained relerant to one prepada grovo health plen, the Portland Kalser Foundetion Health IIan. The universe 1noluaed all physioians who had practioad as full-time, saleried stafs in Kaseer at any time siros 1945 when Kalser was eirst oponed to the public.

Indicatore wore obteined from verlous souroes of data. The Kalser perconnel recores provided data on physiciane' soclel charactersstica. Data on the status of Kas ser came from an offeial salaxy sohedule and xeooras of peroomel advertisemento. Informants wer used to rank medical schoole cnd the AMA' s Directory of Aporoved Internghipg and Residencles provided a ranking of tescing hosptals.

Tho eviance fow the firsi hypothess was generally negative. The aeta indicatso that altinough the status of 
Kalser had increaced over the years, the status of physiclans entering Kaicer had docreased. This conolusion was reached on the basis of lindinge using prestige of medical school as an indicator for physicians' achleved status as woll as findings using nationality and length of practice as indicators for their ascribed status. Thus, the first hypothesis of this study had to be rejected.

The evidence for the second hypotheste wae inconolu81vo: It indicated that as the atatus of halaer incroaged, the percentage of high atatus recrults fros certain positions with intrinsic reverds stmilar to Kalser's decreased, whereas the percentago from other postlions increased. High status physiclens have logs irequently enterea Kalear a) having helo positione emphozizing the scientiflo aspecta of care, b) having membershtrs in solentific or specialty oocleties, c) having changed the location of their practice, and a) heving changed tholr spectalty. They have more frequently entered Kalser a) having had postgraduate training, b) having had at least flve ycars of training, c) having hela Jobs in bureaucretic contexta, a) having greduated frorn realoal schools in the North Central and Western states, and e) having ensaged in two or more different types of activ1t1es. In sum, 1t was unclear whether the second hypothesis should be accepted or rejected. 


\section{MOBILITX OF FHYGTHASS INTO FHEPAID GROUE HEALTH FRAORICA: A CAEE STUDE}

\section{by}

ANN SCHKOEDER SATO

A thesis subpltted in partial fuldiztent of the requircmoris for the degree or

BASTER OF AETS

in

SOCIOTOGY

Portlend State University

1970 


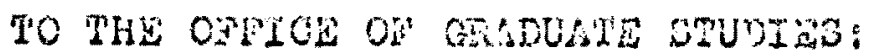

The rembers of the commation approve the theos

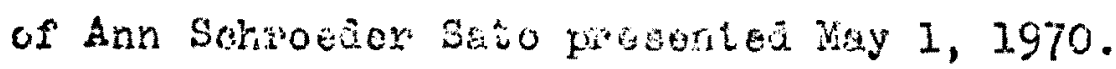

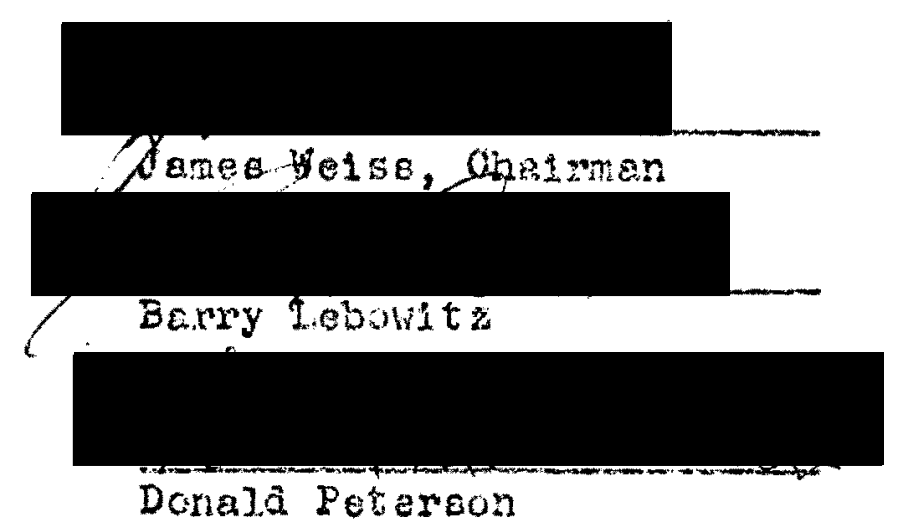

\section{APPROVED:}

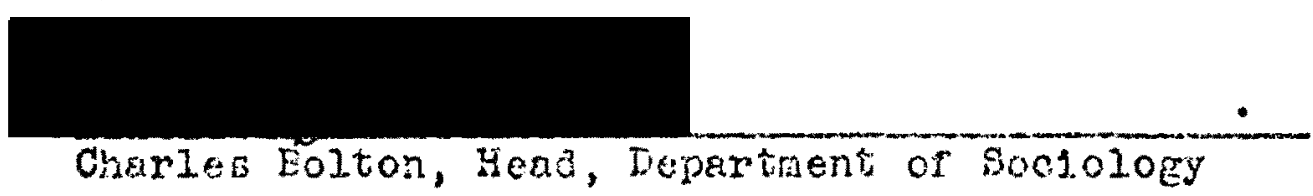

Frory L. Roberta, Aeting Dean of Gaduzte itudes

Wey 1, 1970 
TABLE OF CONTENTS

PAGE

LIST OF TABLES . . . . . . . . . . . . . . . v1

LIST OF FIGURES . . . . . . . . . . . . . . $\mathrm{x}$

CHAPTER

I INTRODUCTION. . . . . . . . . . . . . . 1

Past studies........... . 4

Theory . . . . . . . . . . . . . 112

Alternative Structural-Functional

Soclal-psychologlcal Approaches

Generation of Hypotheses fiom

Blau's Exchange Theory

12

14

II METHODOLOGY . . . . . . . . . . . . 22

Sources of Data . . . . . . . . 22

Design ............... . . . 23

Uni veree

Controls

Tabie Setup

Indicators . . . . . . . . . . . 29

Stetus of Physicians
Positions Drering Intringic newaras Sillilar to Kalser'g

Statue of Katser

III FINDTNGS: STATUS OF DOCTOAS ENIERTMG KAISER 55

Data on Hypothesie one When Ashisved

Status Is the Dependent Variobie . 56

First Inalcator ror Achleved stutus 55

Second Indeator for Achleved Ststus 79 
Thira Indicator for Achieved status

Summary of Data on Achievod statue of Phyoicians

Data on Hypothesis One When Ascribed

Stetus Is the Dependent Variable.

First Indicator for Ascribed Status Second Indicator for Ascrlbed itetus Summary of Data on Ascribed Status of Physictans

Summary: Hypothealo One . . . . . 95

IV FINDINGS: POSITIONS OCCUPIED BY DOCTOES

PRIOR TO ENTERING KATSER . . . . . . . 97

Data for Hypothesis Two . . . . . . 99

Positions Orfering the Opportunity for a More Scientilic Practice

Positions Offering the Opportunity for a Change

Summary

Data againet Hypothesis Two . . . . 107 Discussion . . . . . . . . . . 111

Is the Opportunity for More Education an Intring1c Revara of Ka1ser?

The Changing Specialty Compostion of Kalsor: A Needed Control?

The Changing Composition of Positions in the Monjcal Professlon: A Needed Control?

sunmary

Summary of the study . . . . . . 119

Problem

Conceptuallation of the Problem 
CHAPTER

PAGE

Diacussion . . . . . . . . . . . 128

Suggestions for Future Research . . . 132

REFERENCES CITED . . . . . . . . . . . . . . . . 133

APPENDICES . . . . . . . . . . . . . . . . . 136 
LIST OF TABLES

TABLE

PAGE

I Ratio of Unaccepted Kaiaes Applicants to Staff Openings, 1943-68........... 40

II Distribution of Kaiger Physicians by Spocialty, 1969 .............. . . 48

III Longitudinal Comparison of Rates of Increase per Year in Incomes of One Group of Kalser Spec1allats (IN-CS-OBG-DD) and of Selr-employed Fhysiolans undsr S1xty m five ............... . 49

IV Comparison of Rates of Increase per Year in Incomes of One Group of Kaiser Special1sts (IM-GS-OBG-PD) and of Self-employed Physlclans under sixty-plve during Selected leriods of Time . . . . . .

v Prestige of Physiciens' Medical School by

Time of Entry into Katser.......

vI Prestige of Medical School by Time of Entry Into Kalser anong Fhysicians from Out-orstate Medical Schools.........

VII Physicians from In-state Medical Schoola by Time of Entry Into Ka1ser . . . . . 
VIII Location of Physicians' Medical School by Time of Entry'into Kalser . . . . . .

IX Frestige of Pnysiciens' Nealcal School by

Time of Entry into Kalser and National1ty.

$x$ Prestige of Medical School by TIme of Entry

Into Kalser among Physlc1ans of Foreign

Birth . . . . . . . . . . . . 71

XI Nationality by Time of Entry into Kalser . .

XII Prestige of Physlcians' Medical School by

T1me of Entry 1nto Kaiger and Length of

Previcus Practice . . . . . . . . .

XIII Prestige of Physiclans' Medical School by

Time of Entry into Kal ser and Active/

Inactive Staff Status . . . . . . . .

XIV Prestige of Phys1clans' References by Time

of Entry Into Kalsor. . . . . . . . . .

XV Prestige of Physicians' Hospltale of Intern-

ship and Residency by Time of Entry into

Ka1ser . . . . . . . . . . . . .

XVI Length of Previous Practice by Time of Fntry

Into Kasser . . . . . . . . . . .

XVII Length of Previous Practice by Time of Entry

into Kaiser and Active/Inactive starf

Status . . . . . . . . . . . . . . 
XVIII Scientific/Cilnscal Orientation of Previous

Position by Time of Entry 1nto Kalser among High Statue Physlcians. . . . . . 101

XIX Sclentiflc and Specialty Soclety Membershipg

by Time of Entry 1nto Ka1ser among H1gh

Statua Physiciana . . . . . . . . . 102

$\mathrm{XX}$ Changes in Location of Practice by Time of

Entry Into Ka1ser among H1gh Status

Phys1c1ans... . . . . . . . . 104

XXI Changes in Specialty by Time of Entry into

Kalser among H1gh Status Physiclans . . . 105

XXII Changes in Activities by Time of Entry into

Ka1ser anong H1gh Status Phys1c1ene . . . 1.05

XXII Postgraduate Training by Tire of Entry into

Kalser among High 3tatus Physicians. . . 108 XXIV Length of Training by Time of Entry into

Kalser among H1gh Status Physicians . . . 109

XXV Bureaucratic/Nonbureaucrat1c Context of

Career by Time of Entry into Kalser among

High Status Physiclane. . . . . . . . . 110

XXVI Regional Locetion of Medical School by Time

of Entry 1nto Katser among High Status

Physiclans. . . . . . . . . . . . 112

XXVII Distribution of Discontinued Job Inquiries and Advertised Job Openings in Kaiser over Time . . . . . . . . . . . . . 136 
XXVIII Median Net Incomes of Selected Groups of Self-employed Physiciano under S1xtyIlve, 1959 and 1963 . . . . . . . . 137 XXIX Long1tudinal Comparison of Starting Salaries of Kalser Radiologiats $(R)$ and Orthopedic Surgeons (ORS) ea Reported in Two Bources of Data . . . . . . . . . . . . 138

XXX Starting Salarles of Kalser Radiologisto and

Orthopedic Surgeons over Time Based on Combination of Data from Official Salary Schedule and Recoras of Personnel. Advert1sements... . . . . . . . . . .

XXXI Long1tudinal Comparison of Starting Salaries of One Group of Kalser Speciallets (IM-GSOBG-PD) to Median Net Incomes of Selfemployed Physicians under sixty-five . . 


\section{LIST OF FIGURES}

FIGURE

PAGE

1 Graph of Starting Salaries of Three Groups of Kalser Specialistis over Time . . .

51

2 Distribution of Cohort of Physicians Entering Kaiser during 1943-53 by Active/ Inactive Staff Status, Year of Resignation, and Prestige of Medical School. . 82 
CHAPTER I

\section{INTRODUCTION}

Common inowledge to tho observer of recent trende in the medical profession 1 a the controversy which has taken place within the profession over the profeasional acceptability of prepala group practice. In light of the American Medical Association'a (AMA's) open oppoeition to prepald group health plans, one might expect that euch plens would be regarded by many physicians as undecirable places to practioe. One might also expect such plans to expertence difficulty in recruiting phyolotang. I

A question arises as to how these barriers to recruitment might be overcome by prepald group health plans. In other words, are these recrultment problem iskely to be long-term or short-term trenda? Assuming that changes in the social characteristics of physiclens entering prepald group health plans reflect changes in problems of recruitment, one might also ask whether or not the kinds of physj.clans entoring prepald group practlce have varled over time. This theols is concerned with the latter question regarding variations in the typea of physicians who enter prepald

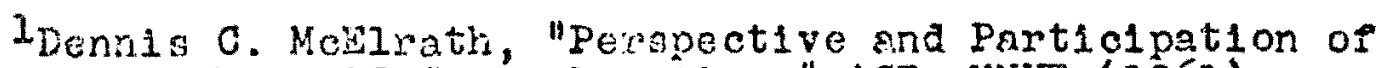
Physiatans in Prepald Group Practice," ASR, XXVI (1961), 601,603 . 
group health plans.

There are two reasons for expeoting that prepald grcup health plans might gein acceptance within the medical profeasion and thereby solve their recruitment problens. It 18 widely recognized that one of the goals which has guided the eatablishment of all prepald group health plans 1 s to provide more efflcient health care services. 2 Accordingly, it is posalble that due to the increasing need for a more officlent provision of health care, the denand for and acceptance of prepald group plane wll 1ncrease. A sccond goal of prepala group plens has been the provision of high quallty medical care in all of the vartous areas of medicino. 3 Accoraingly, the possibility arises that prepaid group plano will gain acceptance by meeting the increasing pressure for high quality medical care to greater degree than tracitional forms. In echleving accoptance within the medical community, prepald group plans would be expected to overcome their recruitient alficulties.

In sum, there 1 s roason to belleve that the reoridt-ment problems of prepald group practice represent ehort-term rether than Iong-term trends. Assuming that changes in tho

2Ernest H. Saward, M.D., Janet D. Blank, and Merwyn R. Greenlick, "Documentation of Prenty Years of Operation and Growth of a Prepald Group Praotice Plan, Medical Care, VI (May-June, 1968 ), 232. Edmund K. Faltermayer, neter Cars at Less Cost W1 thout Miracles," Eortune, LXXXI (January, $1970), 52-83,126$.

3"Glant Group Practice Heads East," Nedical Worid News, November 1, 1968, p. 48. Fal tormayer, Fortwiro, IXXXXI (January, i970), $83,126$. 
sooial characteriet1co of rooruits replect chengesian rocrultment problems, then there 10 also roason to belleve that the social characteristics of physlelang entering prepald group health plans alnce their inception have systemat1cally varled over time. Such veriation presents a problom for research, namely, to inquire into the direction of and reasons for the variation. The task of the present thesis w1ll be to "solve" this probled.

A soolologloal approach will be uecd to gulde the present research on varlations in the sockal charaoteristics of physiolans entoring prepald group practice for two roacons. First, manpower, 1.e., porsonnel, is an important resource with farmeaching consequences far any collectiv1ty. Blau states that:

Another alstinotive charactoristio of intergroup relations is that they involve mobility of individuals Iror group to group. . . The major patterns of these movemente rederine the boundasies of the aubaiructures in the macrostructure and modify thoir internal structuros. 4

In other words, changes in the peraonnel of a given colleotivity affoot the internal eiructure of the collectivity as well as the relations botween the colleotluty and others. The first reason for the soclologlcal approach of this thesio 18 that monpovior, or personnel, 18 an important Boclologlcal variable.

4petor M. Blau, Exchange and Power 1m Soc1al Life (New York: John W1ley \& Sons, Inc., 1964), p. 295 
The second reason is that changes in the personnel of a given collectivity may bo acocunted for, at least in pert, by soclological variables. Elau goes on to state that: "The origin of these patteins of moblity 19 a.loo found in the intorrelated statue structures."5 Accordingly, a 60010logical approach should be capable of predicting the direction of and giving reascna for veriations in the linds of physiclans who have entered prepald group plans sinco these plans were first instituted. Therefore, this thesis w111 use such an approach to describe and partially accourt for varlations in the Boclal characteristics of physlcians who have entered propala group practice. 6

\section{PAST STUDIES}

As otated above, the problem of this thesis 18 to doscribe and account for variations in the types of

5Ib1d.

6 With the help of the classification of hypotheres found in McGinnis, the researoh objectives of this thesis can be stated more precicoly as rollows: finitely condit1onal hypotheses wil be generatod regarding variationg in the eoolal. characteristics of physicians who have entered prepald eroup practice. Such hypotheses will not be puraly descriptive, when this term me ens that ". . no cond1tions are established regarding the relation of the variables under consideration to any others." Ne1ther w1ll they be purely explanatory, when the term indicates that . conditions are specified for the variables $x, 6$ and an infinite number of varlables $z_{1}$." Rather, the hypothesee of this study w1Il be finitely conditionsl, meaning that ". . a condition of statietical independenco is required betveen varlables $x, y$ and a finite number of other variables, $z_{1}$, if the hypothesis is to be true." Robort Meginnis, "Randorization and Inference in Soc10logical hesearch," Aśn, XXIII (1958), +11-412. 
physicians entering prepald group practice. A number of soclologlcal concepts can be used to approach th1s problem. From the perspeotive of the individual we can speak of mobility, whlch, in the broadest senso, can be deflned as the "movement of peraong. . . through the social structure."7 Or, we oan talk of caroers, 1.0., typlcal sequences of movement among a set of positions. From the perspective of the organization (e.g., a group of physiclans in a prepald group health plan) we can spoak of recruitment, 1.e., filling positions with personnel according to a set of standarda.

The problem with which this thesis deals has not been raised before. The literature on soclal moblitty and recruitment $^{8}$ has generally pocused on intergenerational occupational moblilty. Among such atudies are two whlch concern phyelclans. Adams studied intergenerational occupational mob1lity among phy 81 clans from 1900 to 1950.9 Colombotos presented data on the rejation between the soc10-economic status (SES) of a phyglcien's fanily of origln (measured by

7 Ne1l J. Smelger and Seymour Martin Lipset (eds.), "Soclal Structuro, Mob1lity and Development, Soc1el Structure and Mob1lity in Economso Devolopsent (Chicago: AI jiñ Fubil shing Company, 1966), p. 2. See also Blau, pp. 162-163.

${ }^{8}$ Studies on recrultment need not be considered separately from studies on mobility and careers sinco the recruitment perspective 18 usualiy usca in combination with o1 ther the mobility or career perspectlve.

9stuert Adens, "Trends in Occupational Origins of Physiclans," ASR, XVIII (1953), 404-409. 
the SES of his father's occupation) and his 1deology. 10

Th1 a focus on intergenerational ocoupational mobility has persioted oven though the concept of moblilty has been defined in more general terms and many other types of mobll1ty, such as intragenerational as well as intergenerational, oducational and geographic as well as occupational, have been deemed worthy of study. In support of a wider focus within studies on mob1lity, Wilensky states:

The resulti affirm the need for diversified analya1a of social mobllity fltting the diversity of modern 119e. They underscore the vondrous varlety of phenomena encompassed by "mob111ty, " placing intergenerational occupational change in peropective as one among a dozen typos of movement.1I

Following W1lensk's suggestion, one can desoribe the movement of physicians between different work contexts (o.g., 6010 practice, prepald group practice, medical schools, hosp1tals, and the public health service) as moblilty in the broad ense of movement through the soclal etructure. However, it is not oasy to identify the dimeneion or dimensione

10John Colcmbotos, "Soclal Origins and Ideology of Physicians: A Study of the Effecta of Early Socialization," Journal of Health and Soclal Behavior, $X$ (Naroh, 1969), I6-29. It $1 \mathrm{~g}$ interesing to note how the dealgn of whis study allows him to 1 gnore problens raised by the diversiflcation of the medical profeselon. His eamplo oxcluaes femalo physiclans as rell as physlcians on full-time ealary (e.g., medical school faculty, full-time hospltal staff, and pubilo health phyelcians). He falls to mention that ho has also excludod physlclans in prepald group practioe.

11Harold L. Wileneky, "Heasures end Effects of Mob1l1 ty," Soc1al Structure and Mob1l1ty, ed. Smelser and Lipset, p. 110 . 
of mob1lity, if any, which this kind of movement enta1la. Obviously this change does not 1nvolve occupational mobli1ty--the physician remains a physiclan. However, it may lead to higher pay or higher prestige for the physlclan and thus would involve vertical moblilty (movement between positions in a status hierarchy). It may also involve geographical moblitty (change in location of rosidence). *Fortunately, there are data which shed light on thio definitional problem. Aocording to Wllensky, there are numerous systews of ranking along which mobility can occur, one of which $1 \mathrm{~s}$ the econonio opportunities of workiffe. 12 In his fector analysis of moblilty he found that the choles between self-employment and working for an employer was one such opportunity. These flndings suggest that the movement of physlclans into solo versus prepald group practice Involves one dimension of moblility, although they do not really tell us what to name tho dimension. Thus, on an empirical basia it appeara legitimate to conceptualize the entrance of phystolans into prepald group plang in tering of moblilty even though previous studies have not done so.

Our review of the literature on social moblilty has revealed that in focusing on only a fen types of mobility, such stidies ignore the conceptual problem ralsed by the movement of phyalclans anong different contexta of work.

$$
{ }^{12} \text { Ib1d., pp. 110-111. }
$$


Likewlae, studies of physlclens' careerg have also 1gnored this kind of problem. Hovever; there appears to be no theoretical justification for their doing oo. Definitions of the term oareer are often general. The notion of orderilness and typlcallty of a sequence of events are the major dofining characteristica of the term rather than a notion of the context of the events forming the stages of a career. Therefore, there appears to be no a priorl reason why a physiclan's "gob" h1story, 1.e., a history of the contexts in which he has worked, would not constitute part of his carcer.

We may cite a varlety of studies on physician's careers, none of which raice the kind of problem with which we are concerned. In "The Stages of a Medical Career" Hall describes the stages of a medical career as 1) generating ambition, 2) gaining admittance to medical inst1tutions, 3) acquiring a cllentele, and 4) developing colleague reletiona. 13 However, although these atages may be typlcal for the private practitioner, they would not be typlcal for tho physlcien who goes into research or teaching, into the pub110 health service, or into prepald group pract10o. In the latter cases the physician elther does not have a patient clientele or else his clientele is acquirea automaticaliy with h1s job. Thus, one shortcoming of Hall's study is the

130swald Haj.1, "The Stages of a Medical Cereer," AJS, LIII $(1948), 327$. 
lack of typicality of the career atages whtch he has delineated.

Another shortcoming of Hall's study is his fallure to deal with the ohanges which may occur in a physlodan's career after he has made his initial efforts to acquire a cllentele and develop colleague relations. It $1 \mathrm{~s}$ posible that the physician's later career is characterized by typlcal patterns of practice in a variety of contexts. However, Hall falls to ralse the question of whethar or not these changes constitute stages in a physician's career. In another study, "Types of Medical Careers," Hall again 1gnores the kind of problem being raiged in this thesis. 14 Ho differentiates types of medical careers along the dimensions of orlentations to patients and to colleagues. However, he does not indicate how different career orlentations lead physlcians to practice modiclne in context varying, for example, in thelr degree of bureaucratization or departure from troditionel forms of practice.

Studies on physiclens careers also were made by Solomon 15 and Liberson. 16 solomon presents data on the

140owald Hall, "Types of Medical Careers," AJS, LV (1949), $243-253$.

15David N. Solomon, "Ethnic and Class Differences among Hospitale as Contingenoles in Medical Careers," AJS, LXVI (1961), 463-471.

16 Stanley Liberzon, "Ethnic Groups and the Practice of Medicine," ASR, XXIII (1.958), 542-549. 
effect of ethnic and class aifferences ewong hospitals on physlotans' careers. However, he considere only an early. stage in the physician's career, namely, no training period. Liberson investigates the effect of ethnicity on the spatial distribution and degree of specialization of physiclans' practices. Thus, h1s study foeuses on one contextual aspect of physicians' practices. Wowever, he falls to conslaer the effect of ethnicity on otber contextual factors, e.g., the degree of bureaucratization of the context in whlch 8 physlcian works.

Only one other group of studies is relevant to the present research, nanely, studies by Ben-Dzvid, 17 MoElrath, 18 and Freldson, 19 which are spociflcally concerned w1th propald group practice. They all focus on the physlcian's role as it is modifled in the prepald group pratice setting and on the physiclan's adjustments to these role changes. Howover, none of thon have a sked how physiclaris come to practice in such a setting in the first place and thus ignore the issue ralsed in this thesio.

17J. Ben-David, "The Professional Rols of the Phys1clan in Bureaucratized Medicine: A Study in Role Conflict," Human Relations, XI (1958), 255-274.

18 McElrath, ASR, XXVI (1961), 596-609.

19Eliot Freidson, Patients' Vlens of Pedical Practice: A study of Subscribers to a prepald Medical plan (New York: Russell Sage Foundation, 196i). 
II. THEORY

Earlier we discussed some componly held vievs on trends in the medical profession in light of the consequences which these trends could have for prepald group practice. It was suggested that propald group plans had overcome problems in recrultment and that the types of physiciana entering prepald group prectice had varled over time. The objectives of the present thesio wore then defined as an attempt to describe and account for variations in the goclal characteristios of physiclans who have entered prepsid group plans since their incoption.

Accordingly, wo need a theory capable of generating a set of operationalizable hypotheses coneerning changis in the kinds of Individuals entering prepald group health plans over time. As the following paragraphs will show, it was found that structural-functional and soclal-psychological. approaches falled to yleld such hypotheseg and thus were unable to deal with the problen of this thesta. In contrast, Blau'o exchange theory in so fax as lit is relevant to social mobility and recruitment vas found to provido the rinds of hypotheses needod. 20

$20_{B 1}$ au, Exchange and Poyer, pp. 294-301. Peter $M_{4}$ Blau, "The Flow of Occupationel Suppiy and Recruitment," ASR, XXX (1965), 475-490. 
Alternative Structural-Functional and

Soc1al-Psychological Aporoeches

One example of a structural-iunctional approach which falled to yleld userul hypotheses for this study is the Davis-Moore theory of atratification. 21 Accordine to Davis and Moore, one functicnal requirement of any soclety is "placing and motivating indiviauals in the social structure."22 The fulfillment of this requirement necessitates the avallability of appropelately motivated and qualified individuals to fill any vacant positions in society. However, such a pool of individuals is not formed automatically when positions are not destrable or when they require excessive training. Hence, soclal stratiflcation, the differential alstribution of rewards to positions, occurs to overcome ouch problems.

In order to determine how the Davis-Moore theory relates to the entrance of physicians into prepald group health plans, 1 will be assumed that at one time prepald health plans were regarded as undestrable places to practice. 23 If one further assumes that a social system's

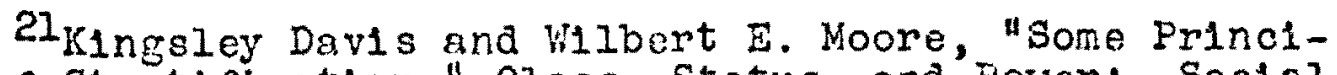
ples of Stratification," Class, Status, and Power: Soc1al Stratification in Comparative Ferspective, ed. Keinhard Bendix and Seymour Martin Lipset (2nd ed.; New York: The Free Press, 1966), pp. 47-53.

$$
\begin{aligned}
& 22_{\text {Ib1d. , p. } 47 .} \\
& 23_{\text {Supre, p. } 3 .} .
\end{aligned}
$$


functional requirements aro belng fulfilled (1.e., that the system is functioning perfeotiy), then the Davis-Mooro theory says that by offering rewards not provided by other positions with olmilar training requirements, prepaid group health plans will be able to attraot eppropriately qualifled and motivated recruits. Alternately, if one assurnes that the oystem $1 \mathrm{~s}$ not functioning perfeotly, then one would expect that inappropriately tialned and notivated individuals would enter prepald group plans.

However, we need a hypothesis about changer in recrultment over time. One can be generated, of course, provided we can spectfy how woll we expect the soclal bystem to function. However, this would bo difficult, since the theory provides no hypotheses about changes in the system's functioning. All we knoi is that its functioning is supposed to be reflected in the supply of recrults to positions. As a result, any hypothosis about changes in the functioning of the system and corrooponding changes in reorultment pattorno would be tautologlcal. Thus, the Dav18-Moore theory of atratification falls to provide the kind of hypothesis needod in the present atudy.

Merton and Kltt's reference group theory is an example of a soclal-psyohologlcal approach which might be useful for generating hypotheses about the kinds of physicians who enter prepald group prectice. 24 One of the propositions in $24_{\text {Robert }} K$. Merton and Al1co $S$. Kitt, "Contributions to the Theory of Reference Group Behavior," Studies in the 
this theory is that moblilty is dependent upon the individual's conformlty to the norms of the group to whloh he hopes to gain admittanco. 25 In other woras, moblilty 1 a dependent upon the Individual's selecting the mewbers of this group a a reference group. In the case of phystclans' entrance into prepald group praotice, one would expect that physlc1ans who conformed to the norma of prepala group prectice would entor prepald group plans more frequently than those who did not conform.

However, the hypotheses needed for the present study concern variations in reorultment over tiae. In terms or Merton and K1tt's theory, we need hypotheses about chenges over time in the kinds of individuals who seleot prepala group practitioners as a reference group. Unfortunately, Mertion and Kitt are unable to account for the Individual.'s Belection of reference groups. Therefore, this theory, $11 k e$ that of Davis and Moore, 18 of limited value in dealirg with the problem of this thesis.

Generetion of Hypotheses fror Bleu's Exchange Theory

In contrast, Blau's exchange theorg ${ }^{26}$ provides the kinds of hypotheses noeded for this stuay. One of the basio

Scope and Method of "The American Soldies" ed. Robort K. Merton and Pau F. Lazingreld (Giencoe, Iilinois: The Free Press, 1950), pp. 40-105.

25 Ib1d., p. 87.

26 One of the basic propositions of exchange theory is that complex social structures and procosses can be 
propositions of exchange theory is that individuals and collectivities follow the most propitable courses of action. Profit is derined in terng of the balance between rewards and costs (1.e., resources galned and lost). Rewarda can be of two basic types-oxtrinsic and intrinsic. Blau defines them as follows:

A critical analytical distinction 1 s that between asBoclations that are intrinsically revarding and those that furnish extrinsic benefits, which are, in principle, detachable from the association 1taolf. . . The basic differonce is between associations that aro considered ends-in-themselves by participants and those they consider means for some further ends. 7

In other vords, to gein a particular intrinsic benefit, one must be a merber of a particular collectivity; however, to bener1t from a given extrinsic reward, it does not matter what collectivity one is in. Examples of intrinsic revards are soclal acceptence and the fulfilluent of the goals of a given organization. Examples of extrinsic rewarda are

accounted for by 6impler processes, namely those of exchange. In Exchange and Pover, Blau def nes exchange as rollows:

Social exchange as here concelved is $11 \mathrm{mited}$ to actions that are contingent on rewarding reactions from others and that cease when these expectod reactions are not forthooning $(p, 6)$.

The basic difference between exchange theory and the other theorles which ve have considered lies in the particular independent variable emphasized. In the Dav18-Mooro theory of stratification $1 t$ was the notion of functional prerequisites of a social aysten; in the Merton-Kitt theory of referenco groups it was the individual's expectations or values held in accord vith his referenco group. In Blau's exchange theory it is the balance between rewards and coste which a particular courso of action would entall.

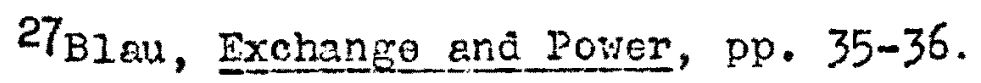


prestige, power, and money. The differontial distribution of extrinsic rewards depines the status, 1.e., position in a ranking oystem, of an individual or collectivity.

Guidod by the proposition that individuals and collectivities follow the most profitable courses of action, Blau develops a number of propositions on mobility and reorultment which bear on our question of the kinds of physiolans who enter prepald group practioe. We will rirst discuss propositions on the relationship or extrinsic rewards to recruitment:

Successrul competition provides more resources for rewarding members and thus spells further success, since the greater rewards discourage members of the collectivity from defecting from 1 to others and encourage member of other collectivitios to leave them for 1 t. 28

Th1 proposition states necessary conditions for 1) an increase in the resouroos alloceted to recrultment by a collectivity and 2) the recruitment of new members. These conditions are described as "succossul competition."

28 Ibid., p. 332. The reader may find himself puzzlea because in this proposition and those that follow Blau does not explicitly state that he is discussing extrinsto rather than intrinsic rewards. However, if one bears in mind that extrinsic but not intrinsic revards are basic elements of ranking systems, then $1 t$ is clear that the notion of extrinsic rather than intrinsic rewards is 1 mplioit in these propositions. For example, Blau refers to increases in rewards. Th1 a 1mplies that the value of these rewards as incentives varies according to their quantity rather than their quality. However, only in the case or extrinsic rewards is the size of the reward significant, and only by virtue of this ract is $1 t$ poasible for this kind of reward to serve as a basis for ranking systeme. Thus, it is clear that Blau is talking about extrinsic rathor then intrinsic rewards. 
The following statenent clarifies the nature of these conditions:

Many groups and organizetions also oompete for a dominant position in the larger social structure, and success in this competition requires a flexible internal status structure that permits an organized oollectivity to attract qualisied contributors by rewarding them with superior status. 29

Hore these conditions are described in greater detall as success in the competition for a dominant position in the larger social structure. In other words, successful compet1tion involves an inorease in status for a collectivity. The previous proposition can now be restated as follows: as the status of a collectivity increases, the rewards which it offers recruits will also increase.

We turn now to several propositions on the relationship of extrinsic rewards to mobiilty:

Membership in various collectlvities is not equally rewarding, which is one factor that promotes mobility ketween them. . . In terms of this factor alone all Individuals have equal incentives to move to the most revaraing collectivity in which thoy can find acceptance. 30

In other worde, Blau suggests that for a given individual mobility is dependent on his having the opportunity to recelve higher rewards. Theae opportunities are dopendent on conditions stated in the following propositions:

While inferior statua in a collectivity givea members most reason to want to loave it for another, ouperior status in it creates the greatest

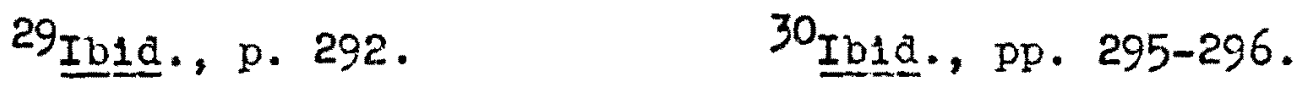


opportunities and potentialities for moving into another collectivity that promises higher rewards. . . The middle stratum in a collectivity... tenda to constitute its solia core of members who neither have much reason for wanting to leave it nor much tempting poteintal for doing so.31

In other words, the opportuntty to take advantage of h1gher rewards depends on the status of the individual beforo mobility: high status gives an individual a greater opportunity than elthor midale or low status. The following proposition 1s suggested: opportunities for higher rewards lead to mobility of high status (rather than low or raldale status) individuals.

The following two propositions have been derlved from Blau's theory of mob1lity and recrultment: 1) As the status of a collectivity increases, the rewards which it offers recruits will also increase. 2) Opportunities for hlgher rewards lead to mobllity of high status individuals. With regard to variations over time in the kinds of physiclans entering prepaid group plans, the following hypothes1s is suggested:

As the status (rani) of prepald group health plans increases, the status (rank) of physiclans entering these plans 1111 increase.

Th1s hypothesis mey be further refined by distingulshing the varlous criterla, 1.e., achlevement and ascription, which govern the distribution of extrinsic rewards:

${ }^{31}$ I $\underline{1} 1 \mathrm{~d} ., \mathrm{pp} .296-297$. 
As the status (rank) of prepald group health plan Incroases, a) the achleped status of physiclans entering these plens will increase and b) their ascribed status w11l increase.

Achleved stetures are those whtch are obtained by virtue of behavioral performances, such as competence. Examples aro prestige, income, and power. Ascribed statuses are assigned by virtue of the situation of one's birth: examples are age, sex, race, and territorial location. 32

It was atated above that extrinalo rewarda are basic components of ranking systems.33 As such, they serve as incentives for moblitty. In contrast, intrinsic rewards are not basic elements of ranking systems. Nevertheless, they are associatod with any glven status, 1.e., social position. Thus, intrinsic rewards may also serve as incentives for moblity.

Intrinsic rewards vary in the degree to which they serve es incentives for moblilty depending on the experis... ence whioh an individual has had with these rewards in other positions. BIau states that:

These expectations of soclal rewards, in turn, are based on the past soclal experience of individuals. - . The study of exchange processes in social assoclations must take into account the ways in which the values of the revards being exchanged are modifled by the expectations of the parteipants and, ultimately, by the previous atstribution or rewards that governs these expectations. 34

$$
\begin{aligned}
& \text { 32smelser, p. } 8 . \\
& \text { 343iau, Exchenge and Pover, pp. 143-144. }
\end{aligned}
$$


In other words, intrinsic rowards serve as incentives for moblilty depending on the status (position) of the ind1vidual. Accordingly, one might expect that the kinds of intrinsic rovards received in provious statuses affect the kinds of individuals who are mobile.

However, before we can specify a hypothesis relating moblilty to intrinsic rewards, we must consider how intrins1c rewards interact with extrinsio rewards in inducing mobility. The problem is that elther extrinsic or intrin61c rewarảs, or both, may serve as incentives for moblilty in any particular situation. Therefore, it is necessary to specify the relationshlp between them.

According to Blau, extrinsic rewards are the most significant factors affecting mobility. 35 However, they do not account for all instances of moblity. Therefore, one might expeot, for example, that the entranee of high status individuals into a collectivity offering fextrinsic rewards coula be accounted for in terms of intrinsic rewards, more speciflcelly in terns of the slmilarity between the intrinsic rewards of the individual' $\mathrm{s}$ past and present positions. Accordingly, the folloving hypothesia 1s suggested:

As the status (rank) of prepaid group health plens increases, high status recrult a will less frequently

35BIau, "Occupational Supply and Recrultment," ASR, $\operatorname{XXX}(1.965), \mathrm{p} .488$. 
come from statuses (social positions) with intrinsic revards simliar to those found in propald group plans.

Examples of statuses (positions) with intrinsic rewaras comparable to those of prepaid group practice are practice within an organizational setting involving the centralization of facilities and positions involving science-oriented rather than practice-oriented activities.

In sum, Blau's exchange theory has enabled us to generate the kinds of hypotheses we need regarding varlations in the kinds of physiclans who have entered prepald group practice. They are as follow:

1) As the status (rank) of prepald group health plans Increases, the status (rank) of physiclans entering: these plana vill increase.
a) The achieved status of these physiclans will increase.
b) The ascribed stetus of these physiclans w1ll increase.

2) As the status (rank) of prepald group bealth plans increases, high status recruits will less froquently come from statuses (positions) with intrina1c rewards similar to those found in prepald group plans. 


\section{CHAPTER II}

\section{METHODOLOGY}

\section{SOURCES OF DATA}

Two sources of information on the kinds of physicians who enter prepald group practice are the personnel recorda of physiclans employed in the Portland Kaiser Foundation Health Plan and the AMA's American Medical Directory. As sources of data for this study, each has 1ts advanteges and disadvantages. The Medical Directory would provide for a comparison of phyolcians entering prepald group prectico with those entering private practice. Such a design would. facilitate the interpretation of findinge by allowing for controls on some of the factors which might account for the results.

Howevor, there is one serlous disedvantage to the data in the Modical D1rectory: it contains only a few 1tems of inforwation on each physician. In contrast, the pereonnol records of Kaloer physicians contain information on several possible indicators for each of the variablea which have been mentioned so far, namely, the status of Kalser, the status of physlclans, and their past soclal positions. Therefore, in spite of the fact that the personnel records of Kalser do not allow a comparison of 
private to prepald group practitioners, theso records were chosen as a source of data.

\section{DESIGN}

The implications of the cholce to use the personnel records of the Portland Kalser Foundation Health Plan as a souroe of data are evident in the research design of this study. First, although the hypotheses of this study concern all prepald group plans, the data cover only one prepald group plen. In other words, the design involves a case study. As a result, no tests of hypotheses are pos8ible. Second, since the data concern only some prepald group practitioners but no private practitioners, the deelgn lacks a control group. As a result, the hypotheses of this study are only partially explanatory. Third, the kinds of data which can be extracted from the Kalser personnel records are for the most part nominal and ordinal data. This sets limitations on the methods which can be used to present and analyze the data.

\section{Undvorse}

As stated above, although the hypotheses of this study refer to the universe of all prepaid group practitioners, the data cover only the universe of physiclans in one prepald group health plan. More specifically, the universe of the present study includes all physlclans who 
have praoticed as full-time, Ealaried staff in the Portland Kalser Foundation Health Plan at any time sinoe Horld War II. Such physiciana are dosignated "active starf" within Kalser and are distingulshed from the courtesy and consultIng staffe, as well as the preceptees (residents). Furthermore, they include only physiclans who practiced in Kalser after 1t had been openod to the publio in 1945, regardiess of whether these physicians entered Kalser before or after 1945. It does not include physicians who practiced thero exclusively during the war years, 1942-45, when the Kaiser Foundation Health Plan vas sun on a strictly eraergency, war-time bae1s. In light of the difference between the context for prectice which Kalser presented during the war and that which it represented after the var, it seens likely that the characteristics of the latter physicians would bo difforent from those of the former, who praotlced In Kaleer aster the war.

Since the universe involves only one case of a prepald group health plan and since the data in this case span the period of time between 1 ts inception and the present, the design of the present research 18 a longltuainal case stuãy. Strictly speaking, no tests of hypotheses can bo made in such a study, since a test investigates the extent to which an hypothesis holds in all the cases of the universe to whioh the hypothesis rofers. As a result, tho generallty of the conclusions which caribe drawn from the 
present study is severely limted. The simllarity between the Kalser Health Plan in Portiand and other cases of prepald group practlce will merely be assumod.

\section{Controls}

Since the universe of the present study contalns only prepald group practitioners in Kaiser, the rosearoh dealgn lacks a control group of private practitioners. Furthermore, since the controls which are used refer almost exclusively to characteristics of prepaid group practitioners rather than private practitioners, the efrects of certain exogenous factors on the findings of this study cannot be ruled out. An example of such an exogenous variable is changes in the composition of the medical profession. This varlable, rather than changes in the status of Ka1ber, may account for the changing attributes of Kaiser physlelans. However, without a control on this exogenous variable, it would be difficult to rule out its effect. As long as Important factors remain uncontrolled with respect to the hopothesis of this study, thls study can only partielly account for the changing characteristics of physiclane entering Kaiser.

The controls used in this otudy involve characteristics of prepaid group practitioners which night have a bearing on their moblilty patterns. These controls were chosen according to two criterle. The first control, on 
Aotive/Inactive staff status, was chosen because it was a mobility variable which, as cuch, might have on effect on the moblilty of physiclans into Kalser.

Activo-inactive staff status indioates whether a physlcian who entered Kaloer is st1ll practicing there or whether he has since left. It seens plausible tnat this variable might be related to the kinds of phyelcians who are responsive to the changes in the extringic rewards of Kalser which presumably aocompany changes in Kalser's status. Two ways in which this might occur are: 1) Inactive staff might represent physiclang who both came to and left Kaiser in search of higher extrinsio rewaras; active staff might have remained in Kaiger because of lts intrinelc rewarda. 2) Act1ve staff may have reralned in Kalser because of the increasing extringic rewards which it prom1sed, whereas inactive staff may have lert because of its unsatiefactory intrinsic rewarda.

Other controls used in the present study are achieved and ascribed status. They were ohosen because theoret1 cally they represent two aspects of atatus, or renk, and as such, one would expect them to be interdependent.

The first hypothesis of thes study that

as the status of prepald group health plans increases, a) the achieved status of physiclans entering these plans will. Increase, and b) the ascribed status of these physicians will increase.

1s based on the esaunption that the achleved and ascribed aspects of status co-vary. However, they may be inversely 
related. In any cose, because of the supposed interrelation of these variables, controls are necessary. AccurdIngly, controls on ascribed status were used in the hypothests on the increase in the achleved status of Kalaer physiclans, and conversely, in the hypothesie on their ascribed status, a oontrol. on achleved status was used.

Due to the small size of the universe of Kalser physiclans $(N=148)$, it was practical to place only one control at a time on any hypothesis. As a result, tho interrelationships among the independent, dependent, and more than one control variable could not be determined with any degree of stability in the data. It was also impractical to place any controls on the second hypothests concerning intrinsic rewards. Thia hypothosio, involving three variables, in effect already utilized one control variable.

\section{Table Setup}

The variables which could be obtalned from the Ka1ser personel records were mostly ordinal and nominal var1ables. Aocordingly, methods appropriate for these kinds of varicbles were chosen to prasent and analyze the data. Croas-tabulation 18 used to present the findings for the hypotheses and to introduce controls in the analysis of the data. Gamme is used to measure the essociation: between ordinal variables. 
The way in whlch the tables vere set up can best be expla1ned step-by-step. The flrst step was to determino the direction and timing of variations in the independent varlable, the status of Kalser. In other words, the years which could serve as cutting points had to be determinod. Because of the small size of the universe of Kalser physiclans, the declsion was made to look at varlations in the status of Kalser in terms of low, medium and high status perlods, rather than to look at such varlations year by year. Three time periods, rather than two, were chosen to avold losing too much information through collapsing. The second step was to declde on the sampling of physiclans within these time periods. As stated in the hypotheses, the focus of this study is on the changing characteristics of physicians who enter Kalser rather than on the changing characteristics of the whole Kalser staff. Therefore, physiclans will be sampled according to the year In which they assumed active-staff status in Kalser, such that three samples w1ll result: physlcians who entered. Kalser during the first, second, and third time periods.

The table setup can now be briefly summarlzed. The Independent variable, the status of Kaiser, is broken down Into low, medium, and high status perlods. The dependent variable may involve any one of a varlety of characteristics of physicians indicative of elther thelr status or the intrinsic rewards asooclated with their past postions. 
Phy glcians are sorted on both independent and dependent variables, e.g., on the status of Kalser in the year that the physicians entered Kalsor, and on theis achieved status.

\section{INDICATORS}

As stated above, the problom of this thesis 18 to account for variations over time in the kinds of physiclans recruited into Kaiser. The analysis of this problem focuses both on the status of Kalser and on the status of physicians who enter Kalsei, 1.e., the proportions of physlcians with high and low status and the proportions coming from positions with intrinsic rewards almilar to and different from those of Kalser. Thus, the varlables for which indicators are needed are the status of Kalser, the status of physicians, and soclal positions offering intrinsic revards almilar to those of Kalser.

\section{Status of Physicians}

Indicators for the status or rank of physlcians include indicators for both their achleved and ascribed ctatusea. Two ascribed statuses of physicians are nationality and length of practice. Within the context of the present study, the country in which a physician's med1cel school is located serves as an indicator of his nationality (1.e., nation of birth), since the former variable appeared to be almost perfectly correlated with the 
latter. Information on location of medical school and length of practice io reported in the Kalser perconnel records.

One kind of achieved status is prestige. The present study includes three indeators for a physician's prestige: the prestige of his medical school, the prestige of his hospitals of internship and residency, and the prestige of his references.

The theory behind the first two indlcatora is clearly stated by Whelor:

Clearly, an important tie [between an organization and a recruit's later career] is the status of the organization in the eyes of the cormunity. . . Thus, whereever the individual's reputation is at stake, his past nembership identities become critical referenoo polnts, quite apart from h1s specific accomplishments or m1sdeeds while in the organization.1

This ouggests that measurea for the prestige of phyolcians' medical schools and hospltels of internship and residency can serve as indicators for physicians' prestige.

Two different methods aro used in the present study to boure the necessary rankings of medical schools and hospltals. A group of Infomants was selected to rank medical schools. In theory, this ranking should serve as an indicator for the reputation or prestige of various medical schools within the meatcal profesion.

IStanton Wheelev, "The structure or Formally Organ1zed Socialization Settinga," Soolelization After Chilahood: Two Egesys, Orvilie G. Brim, Jr. and stanton Wheler (Nov York: John Wiley á Sons, Ind., 1966), p. 96. 
Following Ford, the ranking of hospltals of intornship and residency is based on the offlclal. AMA rating of such hospltals. 2 Accordingly, a high-status hospital is a major teaching hospltal, 1.e., a major unit in the teaching program of an affillated achool. A middle-status hospital 18 a minor teaching hoopital, whlch is affiliated with a medical school but which 1 is used only to a limited extent in the school's teaching program. 3 All other hospltals, 1.e., non-teaching hospitals, are called low-status hoapitals. The data on this rating were secured from the AMA's Directory of Approved Internehips and Residencieg, and the data on physiclans' hospltals of internship and residency and medical schools came from the personnel records of Kalser.

The third indicator for a physictan's status is the prestige of his references. It is based on the assumption that like past organizational afflliations, references serve as symbols for an individual's prestige in situations where more intimate knowledge of the individual's past 10 unavallable. In other words, the prestige of an individual's reference is used as an indicator for the individual's

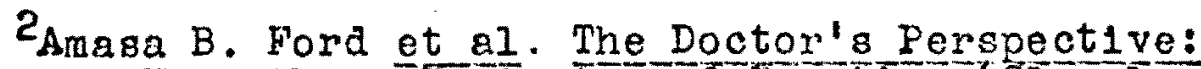
Phys1c1ans Viev the1r patients and Practice (CIeveland: The press of Case iestern heserve University, 1967), pp. $116-118$.

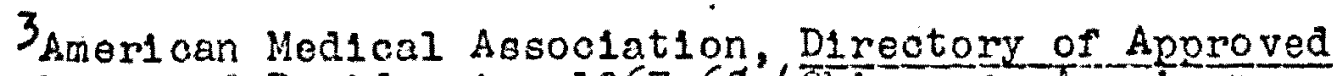
Internships and Restdenc1es $1267-68^{\prime}$ (Chicago: American Medical Assoclation, 1967), p. 77 . 
prestige. Acoordingly, in the present study the prestige of a physlolan's references is used as an indicator for his status.

The prestige of a reference was inferred from the prestige of the organization with which he was affillated during the time he knew the physlcian whom he recommended. Accordingly, high-status references have affiliations with medical schools or with major teaching hospitals. Middlestatur references are affillated with minor teaching hoopitals. All other references are designated low-status references. The sources of data relevent to this indicator were the personnel records or Kalser and the Directory or Approved Internships and Residencies.

Positions Offering Intrins1a Rewards Similar to Ka1ser's

Within the context of the present study, direct Indicators were lacking for the intrinsic rewards of Kalser a. well as for the similarity of the intrinsic rewards assoclated with Kalser and other positions. Therefore, the Indicators for physiclens' past soc1al. positions having Intrinsic rewards slmilar to those of Kaiser are indirect rather than direct.

Data on the intrinsic rewards of prepald group practice were found in printed statements made by physiciens about prepald group practice. Examples of auch intrinsic rewards are the following: the opportunity to practice 
more scientifically and the opportunity to further one's eaucation. 4 These printed statements were used becauee they involved the perceptions and values of physicians concerning prepald group practice. As such, they should indicate the intrinsic rewards of Kaiser as perceived by potential Kaiser recruits, given the following assunption: lacking exporlence with the actual rewards of Kalsor, these recrults would bo likely to evaluate Kalser in terms of pro and con statements made by other physiciens about prepaid group practice.

Other kinds of intrinsic rewards were identified which, although they may not bo recognized as such by phyalclans, may predispose physiclans to enter Kaiser. It was assuned that various aspects of the situation of tho Kalser recrult or staff member are intrinsically rewarding. Examples of such intrinsic rewards are the opportunity for more convenient access to facilities, 5 the opportunity for

${ }^{4}$ G. W. Hunter, M.D., "Jolning," The Mhyslc1an and Group Practice, ed. Edvin P. Jordan, M.T. Thicego: The Year Book Pubilshers, Inc., 1958), pp. 41-lu2.

5 Ryack also recognizes the advantage of convenient access to fac1lities in the situation of the prepeld Eroup practitioner:

There are a number of potential advantages to group practice: the pooling of the akills of a number of specialist to serve the special needs of the patient; salutary effeots of the doctor belng subject to observation by his peers; easy access to the services of specialists at little or no additional costa; lower costs through pooling of capital investment; stabilized incone for the doctor as he shares in the total reoelpts of the group; fuller 
a change, and the opportunity to live in the West.

Positions or sets of positions characterized by Intrinsic rewards similar to those of Kaiser were ldent1fled in the same manner as the above-mentioned rewards of Kalser. In light of certain aspects or the structure or situation of these positions, it was assuned that they offer rewards similar to Kalser's. For example, the position of postgraduate student, like that of the Kalser physicien, provides the intrinsic reward of the opportunity for more education. Other examples are listed below (For more detall on these indicators, see Tables XVII-XXVI):

Intrinsic Rewards of Ka1ser

Opportunity for more education

Opportunity to provido more scientifio care
Positions offering S1m11ar Rewards

Postgraduate student

Career involving extensive training

Specialty or selentific society memberships

Previous position emphasizing ocientific rather than clinlcal aspects of care

Career in bureaucratic context

Opportunity for more conventent accoss to

facilities

Opportunity to live in the West

Opportunity for a change
Medioal school student in the West

Career of changes in specialties Career of chenged in location of practice

Career of changes in activitios

use of anclilary personnel and equipment. Elton Reyack, Professional Pover and American Mediclne: The Economics of the American Hedical Assoctation Toleveland: The World Publishing company, $1967 \%, \mathrm{p}$. 150 . 
Status of Ka1ser

Agsumptions behind the Indicators. In the present study there are two Indicatore for the status or Kalser. One 1o the ratio of unaccepted applicants to staff position openings in Kalser. Another 1s a compartson of the rates of increase over time in the staxting salaries of Kaiser specialists to the rates of increase in the incomes of eelf-cinployed physiciens under sixty-five in the United States.

The first indicator is based on the following assumptions: 1) As the status of a collectivity increaser, the demand for 1ts job openings w1ll likewise increase. 2) Tho demand for these openings is reflected in the ratio of job applications from individuals who take jobs elsewhere to job openings. 3) In turn, this ratio is refleoted in the ratio of alscontinued job inquiries to job openings. Since the Kalser records on alscontinued job inquiries were avalieble, it was feasble to ure the ratio of unaccopted applicants to staff position openings as an indicator for the status of Kalger.

The second indicator is based on Blau's theory of moblilty and recruitment. According to Bleu, changes in the status of a collectivity involve changes in the amount of resources which are used to reward koth new and old 
memberg. 6 starting salaries, which reflect the anount of resources allooated to rewaraing new members, can thon servo as an indicator for the status of a collectivity. Therefore, in the present study the rate of increase (or decrease) In the starting selaries of Kalser physlclans 18 used $8 \mathrm{~s}$ an indicator for the status of Kaiser.?

Since statue refers to a position in a ranking system, the status of any given collectivity is relative to the status of privato practice as well as to the status of other segments of the medical profession. Therefore, ind1cators for statua, such as the rate of increase in starting salarles and the ratio of unaccepted applicants to etaff position openings, should bo expressed in relative rether than absolute terms.

However, data on the demand for the position of private practitioner, which might have been used to standard1ze the data on the demend for positions in $\mathrm{Kalser}$, were not avaliable, although data on the income of private practitioners were. 8 Therefore, the present etudy includes one

6 Supre, pp. 16-17.

7Data on the gtarting salaries of Kalser physiciana wero socured from the Financial Division or Kalser and froin the records of personnel advertisements.

SThe following sources of data on the incomes of private practitioners were used in the present study: Phys1cians Earnings and Expenses: A Reprint of Art1cle日 Based on Hedical Economer Continuing Survey 1960 Toradeil, N. J.: Meuical Economics, Inc., 1960 ; "Results of Medical Economics' First Annual Checkup of Fhysj.clans' Economic 
absolute and one relative Indicator for the status of Kaiser.

In standardizing the data on the starting salaries of Kalser specialists with respect to comparable data on private practitioners, it would have been desirable to have data on the beginning incones of specialists in private practice. However, due to the lack of such data, it was necessury to use data on all private practitioners under sixty-rive and to assume that within the context of the present study the latter data would be representative of the former data.9 Accordingly, the second indicator for the status of Kaiser involved a longltudinal comparison of the starting salaries of Kaiser spacialists to the incomes of all self-employed physlcians under alxty-flve.

Health," Medical Economica, November 2, 1964, pp. 61-107; and Elton Hayack, Professional Power and American Medicine. It should be noted that hayack had access to unpubilshed data from the Quadrennial and Continuing Surveys conducted by the journal Medical Economica. The data reported in Physlcians! Earnings and Expenses and "Physicians" Economic Health" a come from these surveys.

9 Actually, the data on all private practitioners may be of just as great utility as that on beginning selfemployed specialists. Although the abcolute size of the incomes of these two groups of physicians is unooubtedly alfferent (gee Table XXVIII, Append1 $X$ B), the rates of incroase in their incomes may be the game.

Data relevant to this problem show that the rates of increase in the income of speclalists as compared to that of all physiclans were not ldentical during two different periods, 1951 to 1959 and 1962 to 1963. During the earlier period speciallst s' incomos increased less rapidly than those of all physlcians (at rates of 5.6 per cent and 8.5 per cent per year, respectively. In contrest, during tho

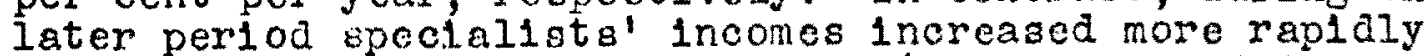
than the incomes of ali physlclans (at rates of 5.5 per cent and 3.1 per cont, respectively). Nevertheless, the 
The method used to make this comparison was first to express the income datia in terms of percentage increases. They were then interpreted as follows: If the rate of increase in the starting salary of the Kalser speclalist excecded the rate of increase in the income of the private practitioner, then 1 was inferred that the status of Ka1aer had increased. Conversely, if the rate of increase in the private practitioner's insome excecded the rate of Increase In the Kalser salary, then 1t was inferred that the status of Ka1 ser had decreaned.10

possibility renains that the differenco botween the ratea of increase in the incoaes of beginning physicleing and 0.11 physicians might of fset the differences between specialints and all physlclans. Unfortunately, we have no avallable deta relevant to this posclibility.

The source for the $1951-59$ rates mentioned above $1 \mathrm{~s}$ Phys1c1ens: Earnings and Expenses, pp. 9, 18. The 1962-63 rates are found in "physicians Economic Health, "Hedical Econom10s, November 2, 1964, p. 105.

10 Another method could have been used to compare the deta on starting salarieg of Halser speclalist 0 to the data on ircomes of private practitioners. The data could have been expressed as percentage differences. When the percentage difference between the Kaloer salary and the private proctitioner's income decreased (given that when the first difference was computed, the Kalser galary vas lower than the private practitioner's income), it woula have been inferred that the status of Kal ser had incresed. Conversely, when the percentage difference increased, it vould have been inferred that Kalser's status had decreascd.

The differenoe between this alternative and the ons chosen can be quickly grasped when expressed in symbols. Let $s_{1}, s_{2}, \ldots s_{1}$ represent the salary of the Kaiser specialist at sucessivo points in time. Simliarly, lot $1_{1},{ }_{1}, \ldots$ $1_{1}$ represent the income of the private practitioner at the same polnta in time. According to the method of comparieon chosen for tinis study, the status of Kaiser $1 \mathrm{~s}$ oald to increase when

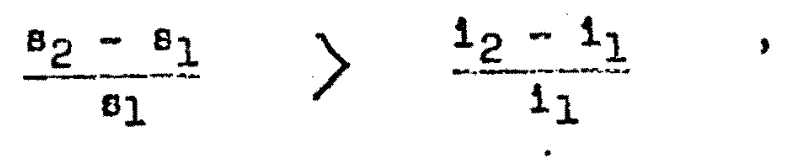


Given Increases and decreases in the statlis of Kalser over time, perlodw when the status of Kalser was low, inidale, and high were inferred on the following basts: The period when the gap between the rates of increase in the incomes of Kalser physicians and private practitioners was the greatest was designated a period of elther low on high status for Kalser, depending on whether the rato of increase was hlgher for Kalser physicians or for private practitioners. Kaiser was sald to have middle status when the gap was the smallest.

Data on First Indicator for Kaiser's statue. The data for the first iniscator of the status of Kas ser whos thet the status or Ka1ser has increased over time. Toble I gives the ratios of unaccepted applicants to stari position

Given that both 8 and 1 have been steadily fncreasing oves time. According to the elternative method, the status of Kaleer is sald to increase when

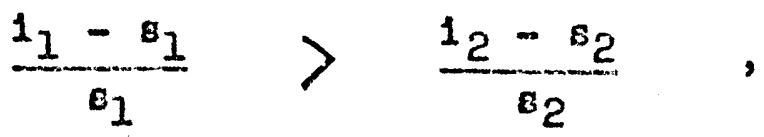

given that il is greater than s.

The second method of comparison was not chosen becauso It involves tre essumption that an increment of for exampie, \$1000 in the incone of a private practitioner is equal to a $\$ 1000$ ralce in the salery of $a$ Kaiser speciellst. It would have been inappropriate to make such an aosumption vithin the context of the present study beckuse Kaiser physiofans receive bonuses and other rringo benoits. Thus, Kaiser ealery dativ do not reflect the absolute size of the income of tho Kalser speciallst. As a result, the absoluse size of an increment in his salary is not directly comparable to an equal increment in the incone of a private practitionex. For more detalis on the problems involved in comparing the incomes of salnoied end self-employed physicians, see Feltermayer, p. 83 ond phesiciang' Earnings and Expenses, po. 52-55. 
TABLE I

RATIO OF UNACCEPTED KAISER APPLICANTS TO STAFF OPENINCS, 2943-68 $Y \quad$ a $r$

\begin{tabular}{|c|c|c|c|c|c|c|c|}
\hline $\begin{array}{c}\text { Before } \\
1962\end{array}$ & 1962 & 1953 & 1264 & 1965 & 1966 & 1967 & 1968 \\
\hline
\end{tabular}

Ratio of Unaccepted Applicante to Staff Opening $g^{a}$

0

$9 \quad 14$

9

$17 \quad 34$

20

35

The fow job inquiries from physiolans whose specialties are not represented in Kalser are not included in these data.

Source: The data on which this table is based are found in Appendix A. The source of these data $1 \mathrm{~s} \mathrm{Kalser} s$ records of personnel advertisements (1962-68) and discontinued job inquiries.(1959-68). 
openings for the period 1943-68. In spite of some inconsistencles, the general trend $1 \mathrm{~s}$ toward more applicants who do not accept positions in Kalcer. (Perhaps they take jobs elsewhere or perhaps Kalser does not want to hire them.)

According to the table, 1 appears that prior to

1962, Kalser had no job applicants who did not accopt positions in Kaiser and also no advertised staff oponinga, thus glving the ratio of zero found in the table. However, this statenent must be qualified for the following reason. Between 1959 and 1962 Kalaer did recelve a few discontinued job inquiries although it did not place any advertisemente regarding otaff openings in the journals. Strictly speaking, the ratio for this period is infinity rather than zero (since the denominator is zero).

Considering the data on which this ratio is based, one realizes that the ratio lacks meaning as an indicator for the status of Kalser. However, on the assumption that the data from 1959 to 1962 can be interpreted in the same way as the data prior to 1959 , then the ratio based on the date prior to 1959 is a meaningful 1ndicator for the statue or Kelsor during the whole period prior to 1962.

The ratio of unaocepted job applioanto to job oponings before 1959 is zero. On the basts of conversations with Kalser personnel responsible for record-keeplng, it seems safe to assume that before 1959 job inquiries were reoelved only from those physlcians who later accepted 
positions in Kalser, whereas none wore recolved from phys1clans who eventually accepted jobs elsewhere. On the sarno baals, it can be assumed that no personnel advertisements were made prior to 1962 . Thus, we can conclude that prior to 1959 there were no applicant for staif positions other than those who eventually became actlve staff and also no etafi position openings. The ratio of unaccepted job appl1cants to job openings before 1959 is then zero. Therofore, although the ratio of discontinued job inquiries to job open1ngs for 1959-62 1s actually infinity, it seens appropriate to express the ratio covering all the years prior to 1962 a zero.

Having found that the ratios of unaccepted applicants to staff openings have been increasing over time, we have conoluded that the status of Kalser has also been Increasing. However, there are two other possible interpretations of these data which must be alsoussed.

Accoraing to the first interpretation, one could argue that the trend in job inquiries reflocte changes in Kalser's methods of recrultment. It appears likely that in the past Kalsen may have exchangod letters only with physiclans who were lnown to be seriously interested in a position in Kalser and to whor Kalser was wllling to offer jobs. Furthemore, in the past interested physlcians were probably discovered difierently. They may have been friends or acqualntences of Kalger physiciane or frienda of friends, 
etc. This would provide an opportunity for an initial informal expression of interest in recruitment and employment. Written communication may have begun later and served only to formalize informaliy mado declstons.

However, in $1962 \mathrm{Kalser}$ begen to place personnel advertisements in the medical journals. Phyblclans unfamiliar with Kelser or 1ts staff were thus given the opportunity to write and find out job detalls. This chango in recruitment methods would then explain why Kalser began to recelve job inquiries only recently.

Although this interpretation of the data on job inquiries seems plausible, it is not supported by the data. It cannot account for the inquiries recelved between 1959 and 1962 before any ads were run in the journals.

A seoond possiblo interpretation of the data on job inquiries is that in the profession as whole, increasing numbers of phyolclans have been taking salaxied positions. 11 Accordingly, the more froquent job inquirles into positions In Kalser reflect the whdespread growing demand for positions not only in prepald group health plans but also in government, industry, public health, eto.

Unfortunately, we lack data relevant to this interpretation and therefore cannot reject 1t. As a result, the data on job inquiries do not provide an unambiguous indicator for

11-Rayaok, p. 46. 
the increasing atatus of Kelser. A comparison of the alary of the Kalser physiclan to the income of the private pract1tioner w1ll. At the very least, such a comparison should make it possible to declae whether or not to reject the interpretation which streseos changes in the medical profes810 a a whole.

Data on Second Indicator for Kaloer'e Status. The second 1ndicator for the status of Kaiser in a conparison of the rate of Increase in the staxting eulariog of Kalser spoclallsta to the rate of increase in the incomes of selfemployed phyalclang under sixty-five. Ag stated earlier, it Involves a comparison of the Incomes of Kaiser physicians to those of private practitioners in order to assure thet the Indicator reflects the relat1ve status or Kalser. However, comparable data on beglnning spoolallsts in private practice could not be seoured. Thus, a potential scurce of error wa introduced into this indicator.

Additional sources of error were introduced by various difflculties encountered in the Kalser starting salery data. The first shortcoming of these data is that it is not olear whether they are mean or median data, or nelther. According to varlous Kalser officlals, the salaries or phyolclang in Kalser vary only by speclalty and by American Specialty Board Certification. The salary date provided by the Financial Division are consistent with this point of view. However, during the data-gatnering stage of research, a variety 
of evidence was revealed indicating that the salarles of Kalser physiclans also vary according to other factors, e.g., a phybictan's prior experience practicing. Therefore, it is necessary to question the representativeness of these data. Fortunately, it was possible to cross-check the off1c1al data with data from anothes source, the recoras of personnel advertisements placed in medical journals. Although the data from the ads cover only the perlod from 1962 to 1969, a number of comparisons ere posolble. (Bee Appendix B, Part II for more detalls.) There appears to be a close correspondence between the two sets of data in the case of four specialties--internal medicine, pediatrics, radiology, and orthopedic surgery. In the case of obstetrics-gynecology, the official data give lower rates than the data from the ads, whereas in the case of general surgery, the opposite 1 s true. Data for four other epecialties were too scant for comparison. The high degree of correspondence between these two sets of data facilitates their interpretation. It seems reasonable to assune that the data in the ads approximate the median salaries of the various Kalser speclalists: most phyoiciana in a given apecialty are probably hired at the advertised rate for that opecialty, although some may be given more and others leas. It also seems ressonable to equate the official data with that in the ads because of the h1gh degree of agrecment found between them. Therefore, we can interprot the more comprehensive official dato ab representing 
the median salaries of the vartous Kalser specielssta.

The second shortcoming of the starting salary date on Kalser physiolans is that its completeness varies between speolaltiea. Date for specialties which were not represented at Kajser unt1l recently, such as urology, psychiatry, and otolaryngology, do not begin until the 1960's. In contrast, date on pediatrios as well as three other specialties begin in the late 1940 ' $\mathrm{s}$.

Although this difficulty might have been dealt with by estimating the size of the missing salaries, this procedure was not followed since the ratios between the saleries of different specialties and between the salaries of aifferent years fluctuated too wlily over time. As a result, it was not possible to compute the average starting salary of tho Kaiser physician over time from the date on the etarting salarles of the various Kalser speciallsts.

In place of dats on the average starting salary of the Kalser physician, falrly comprehensive data on the starting salarles of one group of specialiats were used. The speclallsts in this group have identical salary schedules. They include interniets, surgeons, obstetrician-gynecologists, and pediatriclens (IM-GS-OBG-PD), and they recelve the lowest salarles of all Kalser physicleins.

Th1s procedure of using data on the salaries of one group of Kalses specialiats rather than data on the salaries of all specialists may seem highly unsatisfactory. Hovever, 
taking lnto consideration tho distribution of Xa1ser physiclan by speclalty, one sees that it may be workablo (Table II). Since seventy-one per cent of the physicians at Kaleer in 1969 and an even higher percentage in earlier years were elther internists, surgeons, obstotrician-gynecologists, or pediatriclans, the data on their salaries are representative of the salaries or most Kalger physiclans. In fact, 1: we had data on the median otarting salary of the Kaiser phystclan, it would probably be the salery of a physiclan coming from this group of specialists.

Therefore, in splte of the shortcomings in the salary data which were just outlined, the data on the starting salarles of the IM-GS-ORG-PD group of Ke1ser specialists WIII be interpreted to be representative of the median starting ealary of the Kalser physician. However, the possibility must be noted that this assuntion may lead to errors in the use of the salary data as an indicator for changes in the status or Kalser.

Table III compares the rates of increase in income per year for self-employed physiclans under bixty-five and for the IM-GS-IBG-PD group of Ka1ser specialists (thoae nost representative of all Kalser physiclans). Around the beginning of the 1950's, we find that the incomes of private practitioners wero rising much more rapidly than the salarles of Kalser physiclans. Over the next ten years Kalser physlolans begsin to cotch up with the private practitioners 
TABLE II

DISTRIBUTION OF KAISER PHYSICIANS BY SPECIALTY, 1969

(Per cont)

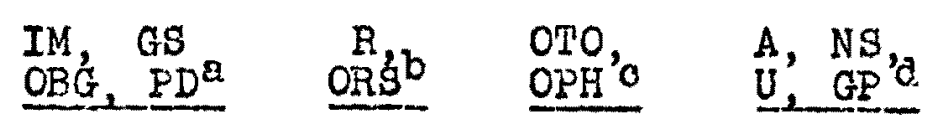

TOTAL

Kelser

Physic1ang

$71 \%$

$7 \%$

$6 \%$

$16 \%$

$100 \%$

$N=96$

Internal modicine, general surgery, obatetricogynocology, pediatrica.

bRad10logy, orthoped10 surgery.

ootolaryngology, ophthalmology.

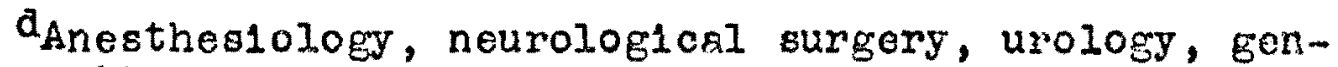
eral practice.

but then slipped behind again. However, we find that by the $1960^{\prime} \mathrm{g}$ the rate of Increase in Kalser galas'sa exceeds the rate of increase in private practitioners' incomes. In other worde, it appears that over the twenty-year period Prom 1945 to 1965, Kalaer occuplea a low, then middle, and finally high status position. 12

12 since data on the beginning incones of self-omployed speciallats were not used in this study, our conclusion that the atatus of Kalser has 1noreased remaing tontativo. Nevertheless, consider how our conclustons would be modjfled if we were using data on self-employed specialists instead of data on all self-employed physlcians. Whereas from 1951 to 1959 the incomes of speclaliets in private practice increased at the rate of 5.6 per cent per year (soe n. 9), from 1949 to 1959 the otarting salarles of Kaider speciallats increased at a rate of only 3.0 per cont per year. similarly, from 


\section{TABLE III}

LONGITUDINAL COMPARISON OF RATES OF INCREASE PER YEAR IN INCOMES OF ONE GROUP OF KAISER SPECIALISTS (IM-GS-OBG-PD) AND OF

SELF-EMPLOYED PHYSICIANS UNDER $65^{\mathrm{a}}$

\section{(Per cent)}

Rate of Increase per Year in Saleries of Period $1948-53$ 1953-56 $1956-59$ 1959-62 - $1962-65$ Ka1ser Spec1alisto

$$
5.7 \%
$$$$
3.7
$$

3.3

$7 \cdot 7$

10.3
Period

1947-51

1951-55

1955-59

1959-62

2962-64
Rate of Inorease per Year in Incomes of SelfEmployea Phystc1ans
$12.8 \%$
5.5
9.5
3.3
8.5

aThe data on whlch this table 18 besed are found in Table XXXI, Append1x 8 . 
Having deterninea the asroction of change in the statua or. Kalser over the yeara, we must now decldo whlch years mark the bounderles between Kaleer's lov, middle, and hlgh status perlods. Although the data on the relative rate of inorease in Kalser salaries soemed sufficiently accurato for the purpose of determining whother or not the status of Kalser had inoreased in the long run, it does not follow that they would ald in deternining exactly when shifte in the general trend occurred. Therefore, the timing of these ohifts wlll be determined not only on the basls of the deta on relative increases presented above but also on the basid of the data showing absolute 1rcreases in the starting salartes of Raleer speclalists over time (F1gure 1 ).

Figure 1 is a graph of the starting alaries of three Groups of Kalser specialiste, the IM-GS-OBG-PD group, a group which includes radiologist and orthopedic surgeons (R-ORS), and the otolaryngologisto (OTO). It includeo all speclalties for whlch there are enough data to reveal

1962 to 1963 the incomes of the former increased 5.5 per cent per year, whlle botween 1961 and 1963 the balarles of the latter increased 4.0 per cent per year.

The conclusion that the status of Kalser has 1ncreased is stili supported though leos dranatically so: al though the rate of increase in Kalser salaries never exceods that of the incomes of self-employed spocialiuts, Kaisen appoers to be slowly closing the gap between its salaries and those of speclallets in private practice. Unfortunately, ve cannot make similar comparisons between the incomes of beginning. physlcians in private practice and in Kalsar. Thus, there 16 no way to deternine the direction of any crror which may reside in our findings as a result of this lack of data on the incomes of beginning physicians. 


\section{Starting}

Galarya

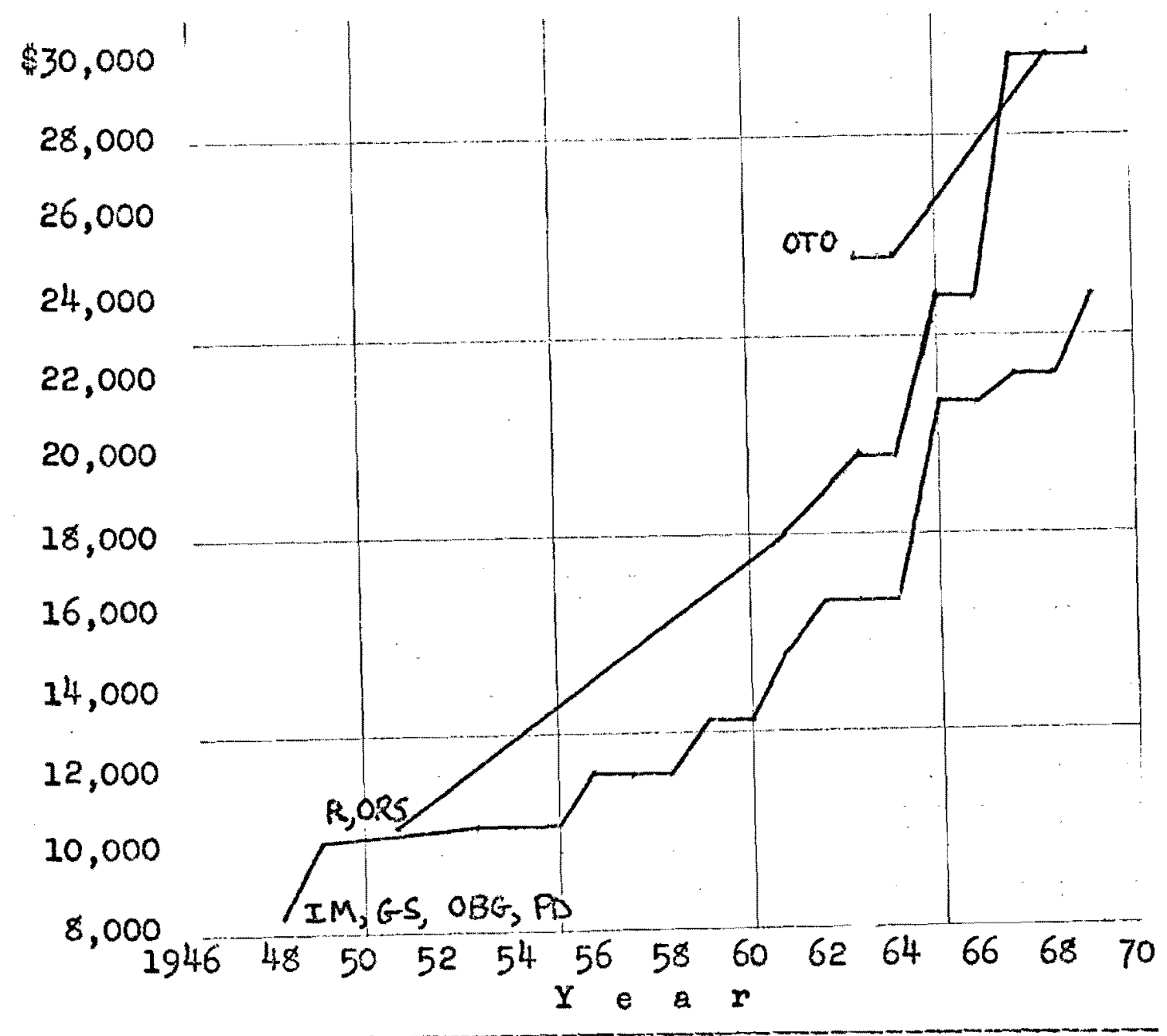

Figure 1. Graph of starting salaries of three groups of Kalser speciallste over tine.

athese starting salaries are reportad at the boardcertifled level; subtract $\$ 1,200$ for nonbosid level.

Source: Date on the IM-GS-OBG-PD and OTO groups of Kalser specialists come from an offlcial starting salary schedule. The salaries of the R-ORS group represent a combination of data from the offlcial starting salary schedule and from records of personnel advertisements (For aeta1ls, seo Appendix B, Part II). 
changlng trenda. One mejor shift in the trend toward higher salarles is revealed hore. It occurs betweon 1963 and 1964 and marks the beginning of a period of sharply increasing salaries. Slmilarly, the data on the relative rates of increase in these salaries show one marked change in the trend toward hlgher calaries (Table III). However, it ooens to occur between 1959 and 1960, rather than between 1963 and 1964. In both sets of data a minor shift oppears to occur between 1953 and 1954 .

By relying more heavily on the absolute salary data than on the relative salery deta, the solloding breakdown for the status of Kalser was defined: The period when the status of Kalser was low rurs from 1943 through 1953 and thus includes a number of years (1943-47) for which no salarg. data were avallable. It is assumed that the variations in salaries during these early years are consistent with the data avaliable in the later years of this time period. The second period, when Kaleer occupled a middle status position, covers the years from 1954 through 1963. Finally, the perlod of Kalser's high status runs from 1964 through 1969. Although this breakdom may not be the only one which can be derived from the salary data, Table IV 1ndicates that 1t 18 a valid one. This table presents a rough comparison of the rate of increase in income per year of Kalser speclalists and all private practitioners for the tiaree time perlods defined ebove. The data reveal thet during the 


\section{TABLE IV}

COMPARISON OF RATES OF INCREASE PER YEAR 'IN INCOMES OF ONE GROUP

OF KAISER SPECIALISTS (IM-GS-OBG-PD) AND OF SELF-EMPLOYED

PHYSICIANS UNDER 65 DURING SELECTED PERIODS OF TIME

\section{(Per cent)}

Rate of Increase per Year in Salaries of

Der1od

$1948-53$

1953-62

$1962-65$

\section{Period}

$5.7 \%$

5.6

10.3

$1951-62$

$1962-64$
Rate of Increase per Year in Incomes of SelfEmployed Physicians

$$
\text { 1947-51 }
$$

$12.8 \%$

7.2

8.5

a The data on which this table is based are found in Table XXXI, Appendix $B$. 
first pertod Kalser salartes were increasing at a much slower rate than the incomes of private practitioners. In the second period the gap betwoen the rates decreased markedly. Finally, in the thitd period Kalser salarles were Increasing more rapialy than the incomes of pilvate pract1tioners. We conclude that the status of Kalser has increased from low to high during the following three perlods: 1943-53, 1954-63, and 1964-69.

We have now examined all the data on the second inaicator for the status of Kaiser. As in the case of the first indicator, we found that the status of Kalser has increased over time. However, although earlier we were unable to reject the alternative interpretation that the data merely reflected trends in the medical profession as a whole, we can now do so on the basis of the date on the relative rates of Increase in Kalser salaries. 


\section{CHAPTER III}

\section{FINDINGS: STATUS OF DOCTORS ENTERTNG KAISER}

Th1s chapter contains the findings for the first bypothesis of this atudy. Since the data, which include a variety of, Indicators and controls, in most cases do not support tho hypothesis, the hypothesis must bo rejected. However, becaure of weaknesses in the date and design of this study, all conclusions are tentative.

The first hypothesis of this study states that:

As the status (rank) of Kaleer Increases, the etotus (rank) of physlclans entering Kalser will increaso.

It was further refined by distinguishing between two components of the dependent variable, the achleved and accribed aspects of status, and restated as follows:

As the status of Kolser increases, a) the achleved status of physiclans entering $\mathrm{Kalser}$ will increese and $b)$ the ascribed status of these phyelclans will increase.

The aiscussion of this chapter vill begin with the findings whlch relate to the achieved status of phystciens entering Kalser. Later we will discuss the findings relating to their asor1bed status. 
I. DATA ON HYPOTHESIS ONE WHEN ACHIEVED

STATUS IS THE DEPENDENT VARIABLE

Three different indicetors for physiclans' achleved status were used: prostige of medical school, prestige of references, and prestigo of hospitals of internehip and residency. We w1ll start with the data involving the firgt indicator. These flndings are of particular importance inasmuch as data for the whole universe of Kalser physiclang were avallable only for this indicator of achieved status but not for the other two.

\section{First Indicator for Achieved Status}

Findings. Contrary to our hypothesiagd expectiations, the data (Table V) show that as the status of Kalser bas increased, the percentage of high status physiolins entereo 1ng Kalser has decreased and the percentage of low stetus physlclans has increased. In other words, 0.8 the statue of Kalser increased, the status of physlcians entering Kelcer deoreased. Although a alreot relationshlp was hypothesized between these two variables, the findings show that they are Inversely related to eome degree. Gama, a messure of the strength of association between two variabies, 18 -0.163 , which indicates thet there 1.8 a relatively weak nogative association betwoen the status of Ka1ser and the status of physicians who have ontered Katser over time.

Extreneous Unoontrolled Variables. Interpretation of these findines is not clearmout. Phey appear to be 
TABLE V

PRESTIGE OF PHYSICIANS' MEDICAL SCHOOL BY TIME OF ENTRY INTO KAISER. (Per cent)

Per1od and Status of Kaigex

\begin{tabular}{|c|c|c|c|}
\hline Medical School & $\begin{array}{c}1943-53 \\
\text { (Low Status) }\end{array}$ & $\begin{array}{c}1954-63 \\
\text { (M1ddIe status) }\end{array}$ & $\begin{array}{c}1964-69 \\
\text { (H1gh Status) }\end{array}$ \\
\hline Low & $39 \%$ & $46 \%$ & $52 \%$ \\
\hline High & 61 & 54 & 48 \\
\hline Total & 100 & 100 & 100 \\
\hline Number & 28 & 41 & 79 \\
\hline \multicolumn{4}{|c|}{ gamms $=-0.163$} \\
\hline
\end{tabular}


contrary to theory. However, this conclusion can be stated only tentatively since the design of this study includes nelther a control group of private practitionerg nor a control on changes in the composition of the mealcal profession as a whole. Thus, it is possible that the finding of a decrease in the status of Kaleer physiclans might be the effoct of changes in the composition of the medical profession as a whole.

For instance, over the pest twenty-five years the percentage of physlcians graduating from low prestige medical schools may have increased relative to the percentage coming from high prestige schools. In other worde, the distribution of medical studento among high and lov status echools may have changed. If such a change has occurrea, then it would be likely that prepala group practitioners as well as private practitioner now more frequently come from low status schools than they did in the past.

Another kind of change in the composition of the medical profession'might also have influenced the findings of this study. Rayack argues that relative to the demand for. medicel services, the stze of the mealcal profession has been decreasing. I Accoraing to him, the resulting shortage of physicians has led, for instance, to increases in the

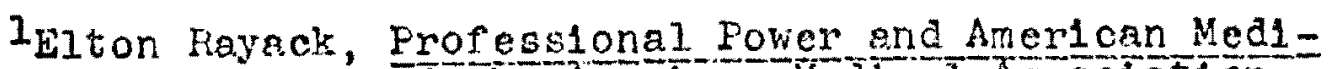
cine: The Econonlcs or the American Medicat Association TCleveland: The World publiening dompeny, 1957\%, pp. 107121 . 
recruitment of interns, residento, and graduates of foreign medical schools by hospltals. Ihls shortage could conoelvably lead as well to changes in the distribution of high and low status graduates anong the varlous sectors of the medical profession. For example, perheps the percentage of physiclans from low status medical schools enterlng both private and prepald group practice has increased relative to the percentage going into research or teaching.

However, if we could eliminate the effect of this variable (the composition of the medical profession) from our findings, we might find that the status of physiclans enterIng Kalser has incressed. Supposo wo could ellminate tho effect of changes in the distribution of medical students among high and low status schools. We then might find that the ratio of low atatus graduates entering Kalser to the total numbor of low status graduates had decreased over timo. We would conclude that the atatus of Kaiser recruita had Increased over time.

Similarly, euppose we could elininate the effect of changes in the distribution of high and low status graductes among various sectors of the medical profession. We might find that the proportion of low atatus graduates emong all phyolclans entering Kalser had increased less rapldy than the proportion of low status graduates among all physicians entering private epecialty practice. Again we would conclude that the status of kalser recrults had increased over time. 
In addition to the composition of the medical profession, there 18 one other extranoous uncontrolled variable which may have an effect on the findings of this study, namely, changes in the recrultmont polloy of Kalger. A number of auch changes appear to have occurred over the years: 1) an increase in the range of speclalties ropresented by Kalser physiclans, 2) expansion of exicting specialty groups, 3) variations in the size of the precoptorship (residenoy) program, and 4) the first employment of general pract1tioners (GP'B) in the emergency room of Bess Kalser Hoop1tal in 1969.

Each of these changes could concelvably have contributed to the 1ncreasing percentage of low status physiclana entering Kalser. ${ }^{2}$ In fact, the last chango apperra to have had such an effect: flve of the seven GP's (seventy-one per cent) graduated from low prestige medical schools, whereas less than forty-olght per cent of the speciallsts entering Ka1ser from 1964 to 1969 graduated from such schools. In other words, the proportion of low status Gr's entering Ka1ser 18 much higher than the proportion of low status

2For instance, the incrense in the range of specialty gervices could have led to en inorease in recrultment from Ka1ser's courtesy and consulting staffs. The physiclans who had formerly provided spacialty care for Kalser patients on a part-time baeis would have been given full-time, actlve staff positions. As a result, the percentage of physicians entering Kalser who vere already a part of the Portland medical community would probably have increased. Th1 a coula concelvably have led to an inorease in the recruitnent of physicians from the Undversity of Oregon, a low prestige school. 
speciallsts.

Furthermore, four of the sevon GP's graduated from the University of Oregon Medical School, a school with low prest1ge. This figure becomes more signiflcant when we realize that all except one of the GP's (the exception was a former preceptee at Kalser) had some connection with the University of Oregon a a medical student, intern, or resident. To the extent that the University serves as the laain source of GP recrultment, it is ilkely that the atatus of GP's recrulted w1ll be affected. To the extent that taik ing the eme:gency room position 10 compatibie with concurrent medical training, the near-by University of Oregon Medical Sckool 1s I1kely to continue to be a source for at least sone of the recrults for the position of emergency room GP.

As the discussion of GP recruitment abows, changes in recrultment pollcy may lead to changes in the status of physiclans entering Kalser. If we could control this factor, wo might find that the hypothesized relation between the status of Kalser and the status of itg reoruits wowld emerge. For instance, if we made a longltudinal. comparison of the status only of those recrults from specialties whish heve been represented at Kaiser since 1943, we might find that the status of these physicians had increased over tine. Unfortunately, without a more comprehensive indiator for changes in recruitment policy, there is no way to place a control on this variable. 
Since we have no controls for these two seemingly important extraneous variables, this study can provide only a tentative interpretation of the finding that as the atatus of Ealser has increased, the status of physiclans entering Kalser has decreased. Howevor, other important extraneous variables can be controllea.

Controls. Four controls were placed on hypothesis one. Following a brief introduction of these controls and our expectations concerning them, the relevant data will be presented.

The first control was in-state/out-of-atate location of medical school. Since there is only one AMA-approved medical school in Oregon, in-state schools rerer exclusively to the Univeralty of Oregon Medical School in Portlend. Outof-state schools refer to all other schools of Kalser recruits. This control, unlike the others, was not introduced on theoretical grounds; 1 was not part of the original research design. Rather, it was introduced later during the analygis of the data on the hunoh that 1t might bo interrolated with the status of physicians entering Kalser.

The second and third controle introduced into the relationship between the status of Koleer and the achleved status of 1 ts recruits were nationality and length of previous practice, two types of ascribed status. The indicator for nationality was the forelgn versus domeetic location of physiclons' medical schools. A U. S. school indicates high 
ascribed status, and a forelgn school inalcates low ascribed stutus. Similarly, in the case of length of provious practice, one or more years' experience in practice is presumed to indicate a higher ascribed status than no experience in practice.

Achlevement and ascription represent two criteria accoraing to which the extrinsic rewards defining an individual's atatus, or rank, are distributed. In other words, etatus, or rank, is made up of two interdependent factors, achleved and ascribed status. Sinee achleved and ascribed status are interdependent, controls on ascribed status were introduced into the relationship between the status of Kaiser and the achleved status of its recruits.

Active/Inactive staff status was the fourth and final control placed on hypothesis one. Active/1nactive staff status, 1.e., whether a physician remaine in Kalser or leaved to go elsewhere, represents the same kind or mobllity fector as a physicien's entrance into Kalsor. Accordingly, one would expect them to bo interdependent in some way. Furthermore, as suggested earlier, 3 one would expect that the introduction of this control would refine the orlginal relationship between the status of Kalser and the status of its recrults by revealing its limiting conditions, such that the original hypothesis would hold true only among active or only among inactive stafi.

$3_{\text {Supra, p. } 26 .}$ 
The introduction of the firet control into the relationshlp between the status of Kaiser and the status of its recruits resulted in the findings presented in Tables VI and VII. These findings show that the original inverse relationship found between the status of Kalser and the status of its recruits remains among both in-state and out-of-state graduates. Table VI reveals that among physiclans from out-orstate medical schools, the original relationship remains although it is much weaker. It involves a shift of only four percentage points as compared to a shift of thirteen in the original correlation. From Table VII 1 it 18 evident that recruitment from the low status Univeraity of Oregon has steadily increased over the years. In sum, we find that the percentage of low status physlclans from both in-state and out-of-state medical schools has increased over time.

In order to clarify the neture of the interrelationship among the status of Kalser, the status of 1ts recrults, and the looation of their medical schools, one can ask whether the control factor serves to refine, expand, or explain the original correlation. These alternative interrelationshipa which Independent, dependent, anà control variables may take are defined by Zelsel as follows: 4 Refinement 1nvolves the introduction of a thira factor into a correlation such that

\footnotetext{
4hans Ze1sel, Say It With F1gures (4.th ed., rov.; New York: Harper \& Row, Publishers, 1957 .
} 
TABLE VI

PRESTIGE OF MEDICAL SCHOOL BY TIME OF ENTRY INTO KAISER AMONG PHYSICIANS FROM OUT-OF-STATE MEDICAL SCHOOLS

$$
\text { (Per cent) }
$$

\section{Period and Status of Kaiser}

\begin{tabular}{|c|c|c|c|}
\hline $\begin{array}{c}\text { Prset1ge of } \\
\text { Med1cal School } \\
\end{array}$ & $\begin{array}{c}1943-53 \\
\text { (Low Status) } \\
\end{array}$ & $\begin{array}{c}1954-63 \\
\text { (M1ddie status) }\end{array}$ & $\begin{array}{c}1964-69 \\
\text { (H1 gh Status) }\end{array}$ \\
\hline Low & $37 \%$ & $39 \%$ & $41 \%$ \\
\hline H1gh & 63 & 61 & 59 \\
\hline Total & 100 & 100 & 100 \\
\hline Number & 27 & 36 & 64 \\
\hline
\end{tabular}

TABLE VII

PHYSICIANS FRON IN-STATE MEDICAL SCHOOLS BY IIME OF ENTRY INTO RAISER

Perlod and Status of Kalser

\begin{tabular}{|c|c|c|}
\hline $\begin{array}{c}1943-53 \\
\text { (Low Status) }\end{array}$ & $\begin{array}{c}1954-63 \\
\text { (Midale status) }\end{array}$ & $\begin{array}{c}1964-69 \\
\text { (High Status) }\end{array}$ \\
\hline
\end{tabular}

Physiclans from

In-Steto

Nealsal Sohools

1

5

15 
the orlginal relationship 1s changed under the new cond1tions of the third factor. 5 Expansion involves the introduction of third factors which "have an Independent influence upon the factor considered as the 'effect' in the orlginal correlation" but which do not modify the original relationsh1p. 6 Explanation involves the introduction of third factors which are not only correlated with the effect in the original relation but "also related to the factor considered as causal. In the original corrolation." 7 In ne1ther refinement nor expansion is the thira factor related to the causal iactor in the original relation.

Apply1ng these alstinctions to the aata in Tables VI and VII, we find that introducing the oontrol on location of medical school does not refine the orlginal correlation: the original inverse relationship between the status of Kalser and the status of 1 ts recruits remains among both out-orstate and in-state reoruits.

Table VIII presento data on the relationship between the indepondent and control variables, the status of Kaiser and the location of reoruits' modical schools. The two variables are only olightly correlated: a shipt or only fifteen percentage points is involved. Since the correlation is so small, the third factor does not explain the original

$$
\begin{aligned}
& \text { 5Ib1d., pp. } 189,190 . \\
& \text { 7Ib1d., pp. 190-191. }
\end{aligned}
$$


TABLE VIII

LOCATION OF PHYSICIANS' MEDICAL SCHOOL BY TIME OF ENTRY INTO RAISER

(Per cent)

Period and Status of Kaiser

\begin{tabular}{cccc}
$\begin{array}{c}\text { Location of } \\
\text { Medical School }\end{array}$ & $\begin{array}{c}1943-53 \\
\text { (Low Status) }\end{array}$ & $\frac{1954-63}{\text { (M1dale Status) }}$ & $\begin{array}{c}\text { I964-69 } \\
\text { Out-or-state }\end{array}$ \\
$\begin{array}{ccc}\text { In-state } \\
\text { Total }\end{array}$ & $96 \%$ & $88 \%$ & $81 \%$ \\
Number & 4 & 12 & 19 \\
& 100 & 100 & 100 \\
\hline
\end{tabular}


relationship. ${ }^{8}$ Instead, medical school location expands the original hypothesis, exerting an independent influence on the dependent variable, the status of physlotans entering KaIser.

Although tisis control on location of a physician's medical school was not introduced on theoretical grounds, it proved to be 1mportant within the context of the present study. Should this variable then be incorporated into future hypotheses about the moblilty of physiclans into prepala group practice? Should it be used in tests of such hypotheses? It should not be, 1 if 1 ts 1 mportance in the present study represents the exception rather than the rule. The medical school situation of Oregon $1 \mathrm{~s}$ atyplcal, there being only one AMA-approved medical school, which has low status. Therefore, one yould expect the signiflcance of this control to be Iimited to the situation of the Kalser Foundation Health Plan in Orogon.

Nationality, one type of ascribed status, was the seaond control introduced into the relationship between the

$8_{\text {Whether a control variable serves to expand or }}$ explain a relationship depends on the magnitude of the correlation betwoen indopendent and control variables. The 1deal case of explanation would be characterized by a perfect correlation botwoen these variables; the 1deal case of expension would 1nvolve a zero correlation. Thus, the weak correlation found between the status of Kalser and the instate/out-of-state location of recruite' medical schools indicates that, strictly spealring, the control variable ne1ther explains nor expands the orlginel correlation. However, recognizing that the distinction between expansion and explanation is relative, cne would describe the effect of this control variable as expanslon rather than explanation. 
status of $\mathrm{Kalser}$ and the achleved status of physiclans entering Kaiser. Table IX shows that among recruits from U. S. medical schoola (1.e., recrults with high agcribed status), the orlginal inverse relationship between the status of Kalser and the achieved status of 1ts recruits remains, although it is alightly weaker. In contrast, the relationship does not appear to hold enong recrults from foreign schools (who have low accribed status). The achleved status of the latter physiclans seems first to increase and then to decrease.

However, because of the amall number of cases of forelgn graduates $(N=24)$, the percentage flgures may be m1bleading. If we disregard the flgures for the first time period which are based on only tro cases, then we rind that the trend between the second and third periods is consistent with the original correlation: the achieved status of forelgn physicians entering Kaiser has decreased.

Another way to $100 k$ at the data on forelgn graduatea Is to use the total number or forelgn graduates es the percentage base rather than the total entering Kaloer in any given tine period. This sorves to eliminate the effects of variations in the total number of low and high achleved status recrults to enter Kalaar in any given time period. When this method of percentaglng 1 s used (Table X), we see that the porcentage of foreign graduates w1th $10 \%$ achieved etatus entering Kaloer has increased more repldiy than tho 
TABLE IX

PRESTIGE OF PHYSICIANS' MEDICAD SCHOOL BY TIME OF ENTRY INTO KAISER AND NATICNALITY

$$
\text { (Per cent) }
$$

\begin{tabular}{|c|c|c|c|c|c|c|}
\hline \multirow[b]{2}{*}{$\begin{array}{l}\text { Prestige of } \\
\text { Medical sohool }\end{array}$} & \multicolumn{2}{|c|}{$\begin{array}{c}1943-53 \\
\text { (Low Status) }\end{array}$} & \multicolumn{2}{|c|}{$\begin{array}{c}195 *-63 \\
\text { (M1dale Stetus) }\end{array}$} & \multicolumn{2}{|c|}{$\begin{array}{c}1964-69 \\
\text { (H1gh Status) }\end{array}$} \\
\hline & Fore1gn & U.S. & Fore1g & U.S. & Fore1gn & U.S. \\
\hline Low & $100.0 \%$ & $34.6 \%$ & $50.0 \%$ & $45.7 \%$ & $75.0 \%$ & $46.0 \%$ \\
\hline $\mathrm{H}=\mathrm{gh}$ & 0.0 & 65.4 & 50.0 & 54.3 & 25.0 & 54.0 \\
\hline Potal & 100 & 100 & 100 & 100 & 100 & 100 \\
\hline Number & 2 & 26 & 6 & 35 & 16 & 63 \\
\hline
\end{tabular}


TABLE $X$

ERESTIGE OF MEDICAL SCHOOL BY TIME OF ENTRY INTO KAISER AMONG PHYSICIANS OF FOREIGN BIRTE

(Per cent)

Per1od and Status of Kaisex

Prestige of Medical School

Low

High

\begin{abstract}
1943-53
(Low status)
\end{abstract}

$4 \%$

0
$1954-63$

(Midale Status)

$13 \%$

13
$1964-69$

(High status)

$52 \%$

18

$$
N=23
$$


percentage of forelgn graduates wh high achieved statue.

If the small number of roreign graduates is taken into account, it seems reasonable to conclude that anong forelgn graduates, as among U.S. graduates (1.e., graduates with both high and low ascribed status), the achieved status of physlolans entering Kaiser has docreased, while the status of Kalser has Increased. Thus, since the orlginal correlation continues to hold among both U. S, and forelgn medical school graduates, it is not refined by the introduction of this control on ascribed status.

Pable XI shows that as the status of Kaloer lnoreases, the percentage of physicians entering Ka1ser from foreign medical schools increases, whlle the porcentage from U. $S$. schools decreases. However, ance these two variables are only slightly correlated, the control on nationallty cannot be sald to explain the original relationship between the status of Kalser and the status of 1ts recruits. Rather, this control on ascribed status appeare to have on independent effect on the dependent variable, the achleved status of physicians entering Kaiser.

The thire control placed on the first hypothesis was length of previous practice, which represents another type of ascribed status (Table XII). This control refines the original hypothesis by revealing one of 1ts linlting conditions. Among physiclans who have not engaged in prectice before comIng to Kalser (who have low ascribed status), the 
TABLE XI

NATIONALITY BY IIME OF ENTRY INTO KAISER

(Per cent)

Per1od and Status or Ka1ser

Nationality

Fore1gn

J. $s$.

Total

Number

\begin{tabular}{|c|c|c|}
\hline $\begin{array}{c}1943-53 \\
\text { (Low Status) } \\
\end{array}$ & $\begin{array}{c}1954-63 \\
\text { (M1dale Status) }\end{array}$ & $\begin{array}{c}1964-69 \\
\text { (H1gh Status) }\end{array}$ \\
\hline $7 \%$ & $15 \%$ & $20 \%$ \\
\hline 93 & 85 & 80 \\
\hline 100 & 100 & 100 \\
\hline 28 & 41 & 79 \\
\hline \multicolumn{2}{|c|}{ gamma $=-0.327$} & \\
\hline
\end{tabular}


TABLE XII

PRESTIGE OF PHYSICIANS' MEDICAL SCHOOL BY TIME OF ENTRY INTO KAISER AND LENGTH OF PREVIOUS PRACTICE

(Por cent)

Prestige of

Medicaíscinocl

Low
HI gh

Total

Number

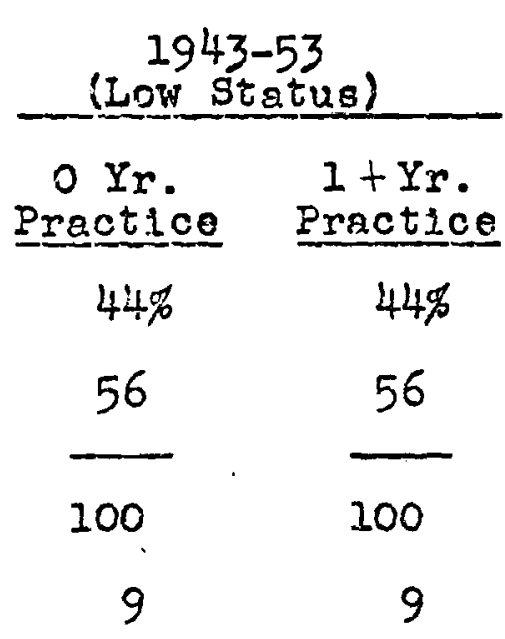

n.a. $=10$ 
relationship between the status of Kalser and the achleved status of 1ts recruits is strengthened, although it alsappears among physlclans who have practlced one or more years (who have high ascribed status).

As hypothesized, both controls on ascribed status (nationality and length of provious practice) are interrelated with physicians' achleved status. In the case of length of previous prectlce, wher a recrult lacks this kind of asorjbed status, the likelihood of his recrultment varies over time with his achleved status. Howover, when the recruit has this kind of ascribed status, the likelihood of his recruitment does not vary ovor time depending on his achleved status--in all three time perioco he is olightly more likely to enter Kaiser if he has high s.chleved status than if he has low achleved status. In other words, the introduction of this third factor refines the original relationsh1p between the status of Kaiser and the achleved status of 1ts recruits by revealing one of $1 t_{B}$ limiting conditions.

In the case of nationality, the relationship among the varlables is different. Over time, whethes a physician has low or hlgh ascribed status (1.e., forelgn or U. S. national1ty), the likelihood of his recruitment depends on his achieved status. The third factor of nationality has an Independent effect on the dependent variable of achieved status in the original relationship. 
Tho active/inactive stapi status of physiclans who have entered Kalser is the fourth control which was placed. on hypothesis one. I'h1 a control serves to reflne the orlginal inverse correlation found between the status of Kaiser and the status of 1 ts recrulto. Table XIII shows that whereas this inverge relationsh1p is strengthened among active staff, it disappears among inactive sterf. Thus, as hypothesized, this control refines the original relationship by revealing one of its limiting conditions: Among active staff, but not among inactive ataff, the status of physicians entering Kalser decreases as the status of Kalser Increases.

Conclusions. A major part of the flndings for the first hypothesis has now been summarized. In these findings prestige of medical school is ueed as an lndicator for a physician's achleved status. With one exception they are based on the whole universe of physicians who have practiced in Kolser since World War II.

Contrary to expectation, the findings do not support the hypothesis that as the status of Kelser increased, the achieved status of physiciane entering Kalser also increased. Instead, 1t hos been found that as the status of Kalser Increased, the achieved status of 1 ts recrults decreased. In other words, these variebles ere inversely rather than airectly releted. 
TABLE XIII

FRESTIGE OF PHYSICIANS' MEDICAL SCHOOL BY TIME OF ENTRY INTO KAISER AND ACTIVE/INACTIVE STAFF STATUS

(Per cent)

\begin{tabular}{|c|c|c|c|c|c|c|}
\hline \multirow[b]{2}{*}{$\begin{array}{c}\text { Prest1ge of } \\
\text { Meãlcal School }\end{array}$} & \multicolumn{2}{|c|}{$\begin{array}{c}1943-53 \\
\text { (Low status) }\end{array}$} & \multicolumn{2}{|c|}{$\begin{array}{c}1954-63 \\
\text { (Middle status) }\end{array}$} & \multicolumn{2}{|c|}{$\begin{array}{c}1964-69 \\
\text { (H1gh Status) }\end{array}$} \\
\hline & Aotive & Inact1ve & Act1ve & Inactive & Act 1ve & Inact1 ve \\
\hline Low & $25 \%$ & $42 \%$ & $36 \%$ & $67 \%$ & $53 \%$ & $47 \%$ \\
\hline High & 75 & 58 & 64 & 33 & 47 & 53 \\
\hline Total & 100 & 100 & 100 & 100 & 100 & 100 \\
\hline Number & 8 & 19 & 28 & 12 & 60 & 19 \\
\hline
\end{tabular}


The four controls placed on this hypothesis also support the negative findings. The introduction of two of the controls, length of practice and active/1nactive stafi statua, led to the refi nement of the original inverse relation between the status of Kalser and the achleved status of 1ts recruits by revealing its limiting conditions. In other words, the original relation held only among active staff and physlcians with no provious experlence practicing but not among inactive starf and physicians with such experience. The other two, nationailty and in-stato/out-ofstate location of medical school, were found to have an independent effect on the achleved status of physiclans entering Kalser. In other rords, the original rolation held among both foreign and U. S. phystclang and enong both instate and out-of-state graduetes.

These findings are tentative for two reasons. First, potentially 1mportant extraneous variables could not be controlled. Second, Indicators used may be weak. Therefore, although it is possible that further evidence would not a.ter the conclusions which he have aratn from our data, it is also possible that such evidence would lead to other interpretatione of the data.

If adaltional evidence providing for more controls were avallable, then any of the following alternative interpretations of our data might be called for. First, if all important extraneous variablos could have been controlled, 
the hypothesizea relationshlp between the status of Ka1ser and the status of 1 ts recruits ight have been revealed. In this case, we would have found that the status of Kalser physlclans had in fact Increased as the status of Ka1ser Increasod. Our firat hypothesls would then have been supported. Second, more adequate controls might have led to the explanation of the unexpected relationship which was found between the status of Kalser and the status of its recrults. In this case, we would have alscovered an intervening varieble between the independent and dependent variables of our hypothesis. We would then have moalfled our hypothesis accordingly. Thira, such controls might have revealed the spurious nature of the unexpected relationship which was found between the status of Kaiser and the status of 1 ts recruits. In this case, we would have found a control variable which accounted for both the statis of Ke1ger and the status of 1 ts recruits. As a reault, it would have been necessery to reject our hypothesis.

If better indicators for the achleved status of phys1clens were avaliable, the findings might support the flrst hypothesis. Th1s posalbility will be alscussed below following the presentation of findings using indicators other than the prestige of a physician's mediaal school.

Second Ind1cator for Achleved Status

The second 1ndicator for a physic1an's achleved status used in the present study was the prestige of his references. 
Unfortunately, due to problems of missing information, the findings using these indicators do not apply to the whole universe of Kalser physlclans. (For more detall on these problems, see Appendix 0.)

Findings. Table XIV shows that the status of phys1cians enterling Kalser has Increased as the status of Kalsor has increased. In contrast to the date where prestige of medical school serves as an indicator for achleved status, these findings confirm our hypothesis. In other worde, these data reveal a direct, rather than an inverse, relationship between the status of Kalser and the status of 1 ts recruits. Furthermore, the association is strong; gamm is 0.554.

Because of the large number of cases for which data on references were missing, a high degree of confidence cannot be placed in this finding. There are twenty-nine cases miss1ng, twenty from the earliest time perlod, 1943-53, and nine from the period 1954-63. Since the period 1943-53 containg data on oniy elght cases, the possiblifty arises that they may not be representative of 2.11 the physlatans who entered Kalser at that time.

The following data suggest that, in fact, the findings for the time perlod 1943-53 are not representotive. The accompanying diagram (F1gure 2) shows the prestige of the medical schools of all physloians who entered Kalser duringt 1943-53, according to whether or not they are still 
TABLE XIV

PRESTIGE OF PHYSICIANS' REFERENCES BY TIME OF ENTRY INTO KAISER

(Per cent)

\section{Period and Status of Kaiser}

Prestige of References

Low

Medium

High

Total

Number

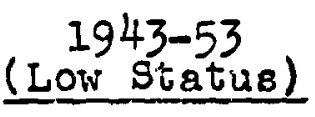

$100 \%$

0

0

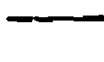

100

8
$1954-63$

(Midale status)

$14 \%$

31

25

100

32
1964-69

(H1gh Status)

$22 \%$

35

43

100

79

n.8. $=29$

samme $=0.554$ 


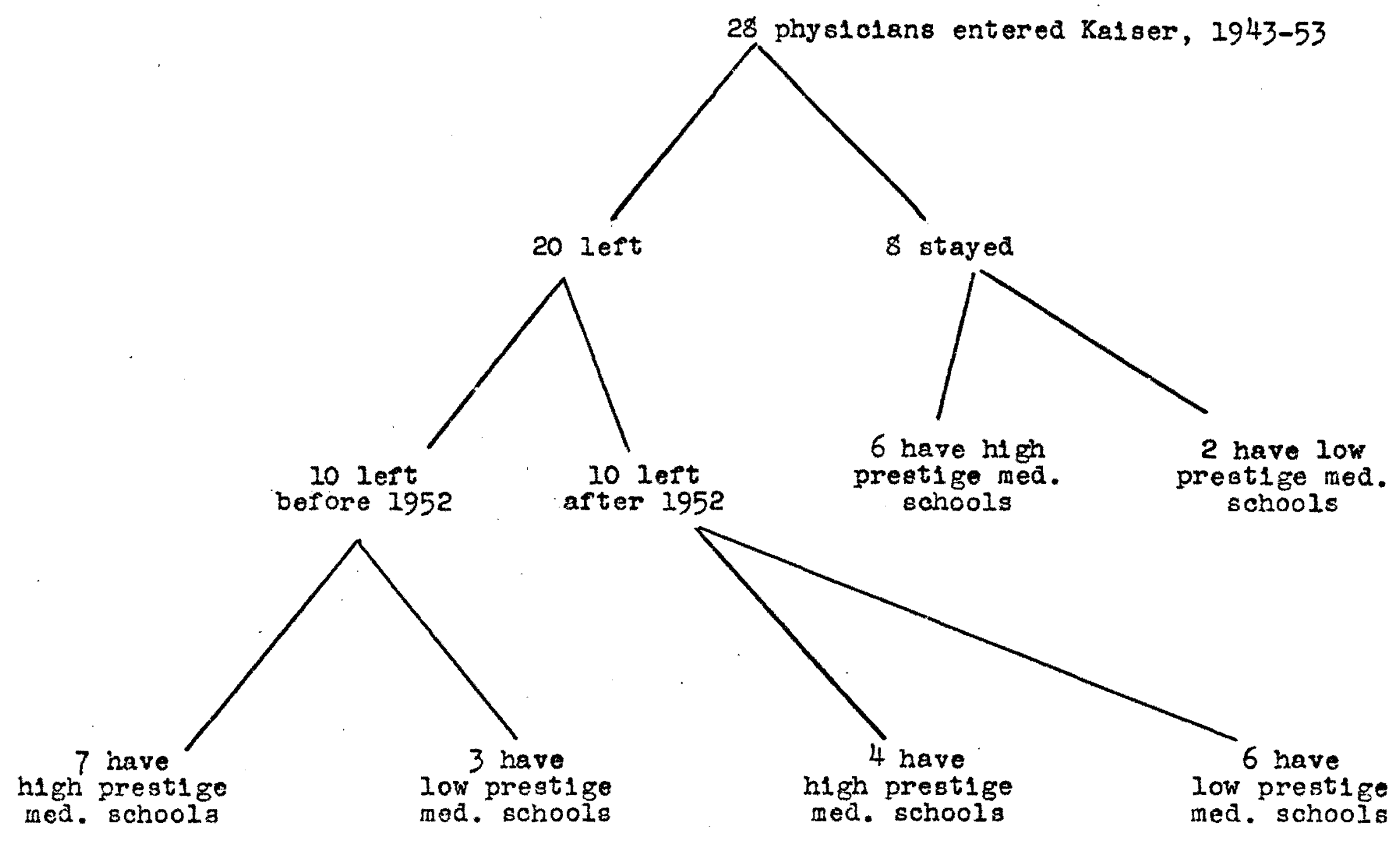

Figure 2. Distribution of cohort of physlcians entering Kalsor during 1943-53 by active/1nactive staff status, year of resignation, and prestige of medical school. 
practicing in Kaiser and if not, according to whother thoy left Kaiser before or aftor 1952. Est1mating that data aro missing for all physiclans who left Kalser before 1952, three-quarters of those who laft after 1952, and one-quarter of those who did not leave (see Appendix C), then one seed that the prestige of the medical schools of physiclans for whom data are missing is higher than that of physlolans for whom data are present. If the two indicators, prestige of roferences and prestige of medical school, are correlated to some extent, then 1t 1s I1kely that the 1943-53 data in Table XIV are blased in favor of low status recruits. If the1943-53 data are blased, then flnding en increase in the status of physicians entering Kalser over time 18 probably an artifact of the unrepresentativeness of the deta which uee prestige of references as an indicator for the status of physiclans entering Kalser.

Extrangous Unconirolled Variables. The finding of a direct relationship between the status of Kaiser and the status of 1 ts recruits (when indlcated by the prestige of their references) may be misleading because the generallty of this relationshlp may bo limited. As discussed earlier, 9 physiclans who have been affiliated with the University of Oregon Medical School at one or more points in thelr careers have been entering Kalser in greater number:. Thus, if a control on University of Oregon references rersus other

$9_{\text {Suure, }}$ lable VII, p. 65, and p. 61 . 
references were placed on the first hypothesis, then it is likely that we would ind the following: 1) Among physic1ans with non-University of Oregion references there has been a decrease in the atatus of physician entering Kaiser. 2) The frequency of physiclans with University of Oregon references, 1.e., high status references (by virtue of their medical school affiliation) has increased over time. If a direct relationship between the status of Kaiser and the status of its recruits is found only among physicians with University of Oregon references, then the generality of this relationship is severely limited. Consequently, it would not lead us to question the validity of the inverse relationship found earlier when prestige of medical achool was the indicator for a physician's status.

\section{Third Indicator for Achieved Statua}

Findings. The third indicator for a physician's achleved status used in the present study was the prestige of his hospitals of internship and residency. Using this indicator, we find that the first hypothesis is supported (Table XV): as the status of Kalser increases, the status of 1ts recruits also increases. (The correlation is fairly strong; gamia $=0.382$.$) Data for only fourteen cases are$ missing. Although eleven of them come from the first time period, data on seventeen cases are present for this period. Thus, although the accuracy of the previous findings which uee prestige of references as an indicator seems highly 


\section{TABLE XV}

PRESTIGE OF PHYSICIANS' HOSPITALS OF INTERNSHIP AND RESIDENCY BY TIME OF ENTRY INTO KAISER

(Pér cent)

\section{Perlod and Status or Kalser}

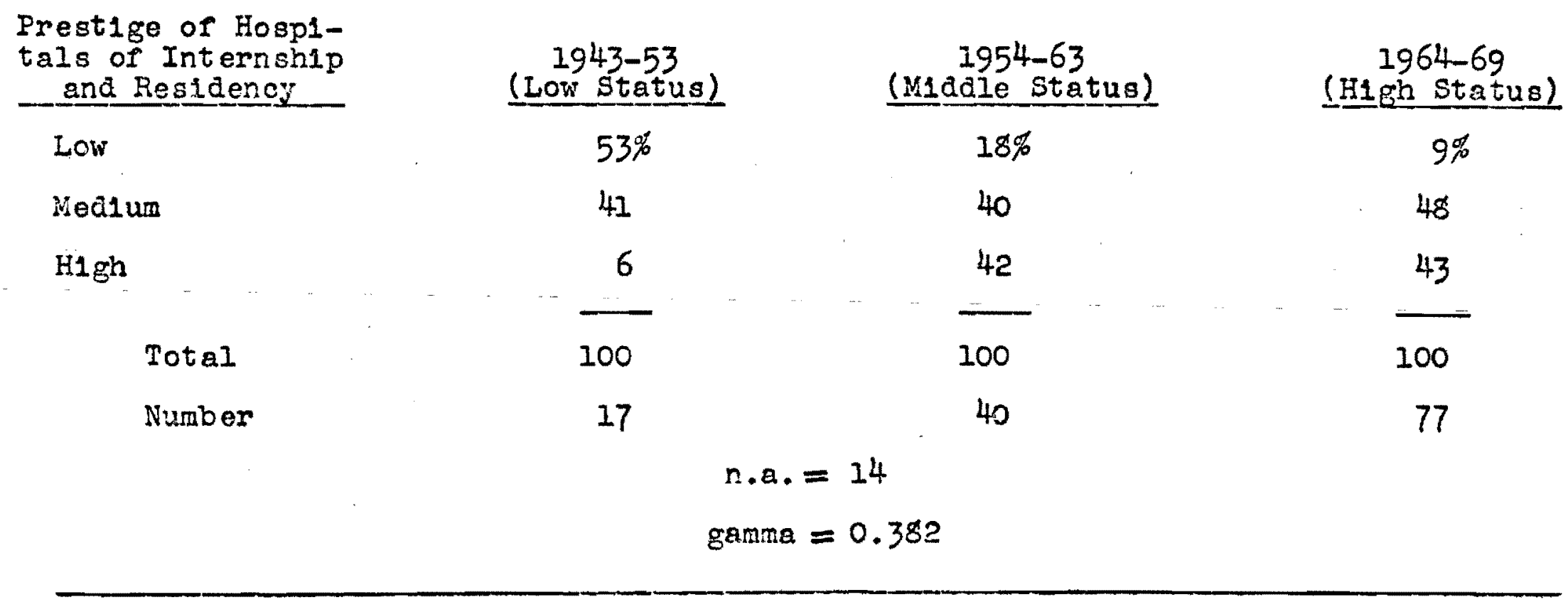


questionable, there are fever reacons to doubt the accuracy of the present findings.

A Val1d Indicator? Asoundng that these findings are representative of the universe of Kalser physiclans, then it is necessary to account for the discrepsincy found between these findings and those where prestlge of medical school serves as an indicator for the achieved status of physicians. Perhaps it arose because one of the indicators for achleved otatus is better than the other, or perhaps nelther indicator ia adequate by 1tself. We will discuse these two possibilities below.

The discrepancy between these two sets of findings may have arisen because the indicatorg prestige of medical. school and prestige of hospltals of interrship and restaency are inversely correlated. If so, physiclans from low prestige modical schools would have high prestige hospitals of internship and residency. They would have enterod Kalser after experlencing upward moblilty during thelr training (1.6., each stage of training was taken at more prestigious center of learning). Although each indicator would be tapping etnilar aspects of status, nelther woula be adequate by itself as an indicator for the achleved status of physicians entering Kalser. Therefore, they would have to be combined to form an index of status.

The discrepancy between the two sets of firdings mignt also have arlsen because the indlcators for achleved status 
were not correlated. If this were the case, then it would be possible that one indicator for achleved status is better than the other in the context of physlelans' job opportunities.

As suggested by soveral informants, the prestige of a physician's medical school way not be an 1mportant factor in physicians' job opportunities. Inatead, as one informant clalmed, the prestige of the specialty program in which a physician recelves his residency training as well as the prestige of the specialist under whom he studies during his residency may be more limportant. In this cose, even tho Indicator used in the present otudy, the prestige of hoopitals of internship and residenoy, woujd not be a sufficlently sensitive indicator of a recrult's status because it leads to a ranking of hospitals rather than of programs and professors within hospitals. Unfortunately, it $1 \mathrm{~s}$ beyond the scope of the present study to answer these questiona regaraIng the validity of various indlators for achleved statis. Nevertheless, the questions must be kept in mind in interpreting the results of this study.

Summary of Data on Achieved Status of Physloians

In sum, the findings for the first variant of the first hypothesis--as the status of Kalser increases, the achieved status of physlclans entering Kelser w1ll increase-are not concluelve. The reasons are alverse: 1) Data on the whole unlverse of Kalser physiclans vere avaliable for only one 
Indicator of achleved status. 2) Difforent indicators ylolaed contradictory results. 3) Important extraneous variables could not be controllea.

Although it can be definitely concluded that the status of Kaiser is essociated wh the status of physicians entering Kaiser, the direction of the relationship 1 is uncertain. When prestigo of medical schools serves as an ind1cator for achleved stetus, we rind that the status of plyysicigns entexing Kalser has decreased over tine. In contrest, when prestige of hospitaj,s of internghip and residenoy $i s$ the indicator, we find that thes atatus has increased, as hypothes1zed. Thus, we camot arinitely rejeot ints rypotks 810.

Aa hypothesized, naticnality, length of previous prastice, and actire/Inactive siarf status wive found to be important controls with respect to the first hypothesis. The importance of the in-state/out-ô-state location of medical school was discovered during the analyois of tho data. Nationality and the in-state/out-or-state location of a recrult's medical school were fourd to have an independent effect on the echleved status of physlcians entering Kaiser. Length of previous practice and active/Inactive atorf status refined the original inverse correlation found between the status of Kaiser and the status of its recruits.

The detalied findings which use prestige of medical school, of hospltals of internshtp snd residenoy, and of 
references as indicators for the achieved etatus of physiclans entering Kalser are llsted belor:

1. As the status of Kaiser increased over time, the prestige of the medical schools of physicians entering Ka1ser decreased.

a. Controls on nationality (as an indicator for ascribed status) and on the in-state/out-of-state location of a recruit's medical school had an independent effect on the prestige of recruits' medical schools. In other words, among both forelgn and domestic phrsicians and among both in-state and out-of-state graduates, the achieved status of physicians entering Kaiser decreased over time.

b. Controls on both active/inactive staff status and length of previous practice (as an indicator for ascribed. status) refined the inverse correlation between the status of Kalser and the status of its recruits by revealing 1ts limit-. ing conditions. In other words, the relationship held only among active staff and among physicians who had no previous experience practicing.

2. As the status of Kalser increased over time, the prestige of the references of physlcians entering Kaiser increased. (The validity of these findings is doubtful.)

3. As the status of Kalser increased over time, the prestige of the hospitals of internship and residency of physicians entering Kaiser increased.

II. DATA ON HYPOTHESIS ONE WHEN ASCRIBED STATUS IS THE DEFENDENT VARIABLE

The second variant of the first hypothesis states thet:

As the status of Kaiser increases, the ascribed status of physicians entering Kaiser will increase.

The following two indicators for ascribed status were used in the present study: notionality and longth of previous practice. As stated earlier, forelgn nationality indicates $10: \pi$ status; U. S. nationality indicates high status. Similarly, the lack of any exporlence in practice inalcates low status; 
one or more years experience indicates high status. We w1.1I begin our discussion of the ascribed otatus of physicions entering Kaiser with the finds rige which lise the first indicator.

\section{First Indicator for Ascribed Status}

The finaings in Table XI, when nationality is the Indicator for ascribed status, are opposite to those hypothesized: as the status of Kalser has increased, the percentage of physicians with high ascribed status (U. S. national1ty) entering Kalser has decreased while the percentage with low ascribed status (foreign nationelity) hes increased. In other words, as the status of Kalser has increased, the ascribed status of physicians entering Kaiser has decreased (gamma $=-0.327)$. Instead of a direct relationship as hypothesized, we find an inverse relationship between the status of Kaiser and the status of its recruits.

Without proper controls, the conclusion that the ascribed etatus of Kaiser recruits has decreased is tentetive. Data found in Rayack 1Ilustrate how critical a control on the changing composition of the medcal profession is for the intexpretation of data involving graduates of foreign medical schools:

The 1mpact of 1mmigration 1s also shom in medical I1censure data. Between 1940 [1950] and 1959 forelgh graduates receiving licensure as a percentage of the totel licerises granted rose from 5.1 to 
19.7 , almost a fourfold increase. 10

In the present stuojy data on the percentage increase in foreign graduates who became specialists in private practice would be needed in order to conclude derinitely that the twofold increase in foreign graduates entering Kalser between 1943 and 1963 represents a decrease in the status of Kaiser recruits.

Second Indicator Por Ascribed Status

Table XVI revealo an inconsistent correlation between the status or Kalser and the ascribed status of its recrusts as measured by length of previous practice (gamma $=0.089$ ). Although the ascribed status of physlciano entering Kaiser decreasos between the second and thira time periods, it increases between the rirst and second periods. (No previous practice indicates low status; one or more years of practice indicates high status.)

The accuracy of this finaing muet be questioned. Since data are missing for ten cages in the first time period, this period includes data on only elghteen cases. However, this problem can be dealt with by introducing a control on activel inactive staff status. This vill allow us to 1solate the ten missing cases among inactive staff; the data on active staff

10 Rayack, $p .123$. The data on which this statement was based (p. i2t) reveal that it is in error. Rayack should have been describing the persod from 1959 to 1959 rather than the pertod $1940-59$. 
TABLE XVI

LENTGH OF PREVIOUS PRACTICE BY TIME OF ENTRY INTO KAISER

(Per cent)

Pericd and Status of Raiser

Previous

Practice

$0 \mathrm{Yr}$.

1 or More Yr.

Total

Number

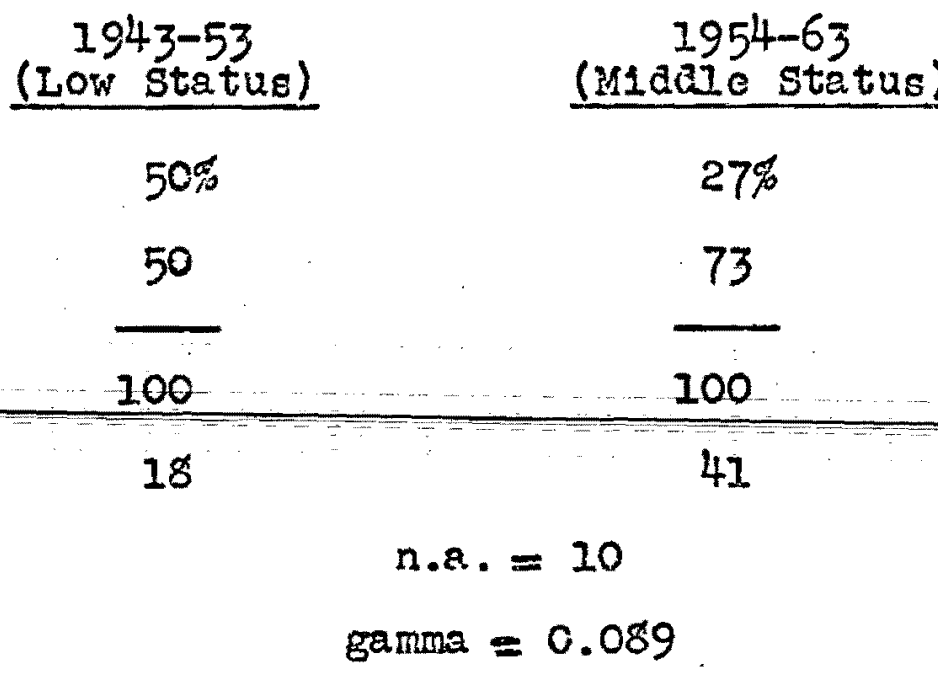

$1964-69$

(High status)

$33 \%$

67

100 
will then be complete. 11

Table XVII shows that the introduction of a control on active/Inactive staff status reveals the interselation between the status of Kalser and the ascribed statlis of its recruits. Among active steff, as the status of Kalser has increased, the ascribed status of its recruits has decreased. However, among inactive staff, the relationship between Kaiser's status and the ascribed status of physicians enter1ng Kaiser is inconsistent, as it was in the original correlation before the control was introduced (Table XVI). Again, the findings fail to support the first hypothesis. Among active staff, the status of Kaiser and the ascribed status of its reorusts (as measured by length of previous practice) aro inversely rether than directiy related. Likewise, in the provious Indings where national1ty served as an 1ndicator for ascribed statug, these variables were inversely related.

Summary of Data on Ascribed Status of Physiciang

Contrary to expectation, we have found that as the status of Kalser increased, the ascribed status of physiciana

$1 I_{\text {Actualiy }}$ one case is still missing from the active staif data. Comperison of the number of cases missing from Table XVI and Table XVII shows that whereas 10 cases are missing from Table XVI, 12 cases are missing from Table XVII. As intended, the introduction of the control on active/1nactivo sterf status alioved us to isolate the 10 cases orlglinally missing from Table XVI. In Table XVII these cases appear in the data on inactive staff but not in the data on active stafr. However, in the process two additional cases turned up nissing. Since one of these is 


\section{TABIE XVII}

LENGTH OF PREVIOUS PRACTICE BY TIME OF ENTRY INTO KAISER AND ACTIVE/INÁCTIVE STAFF STATUS

(Per cent)

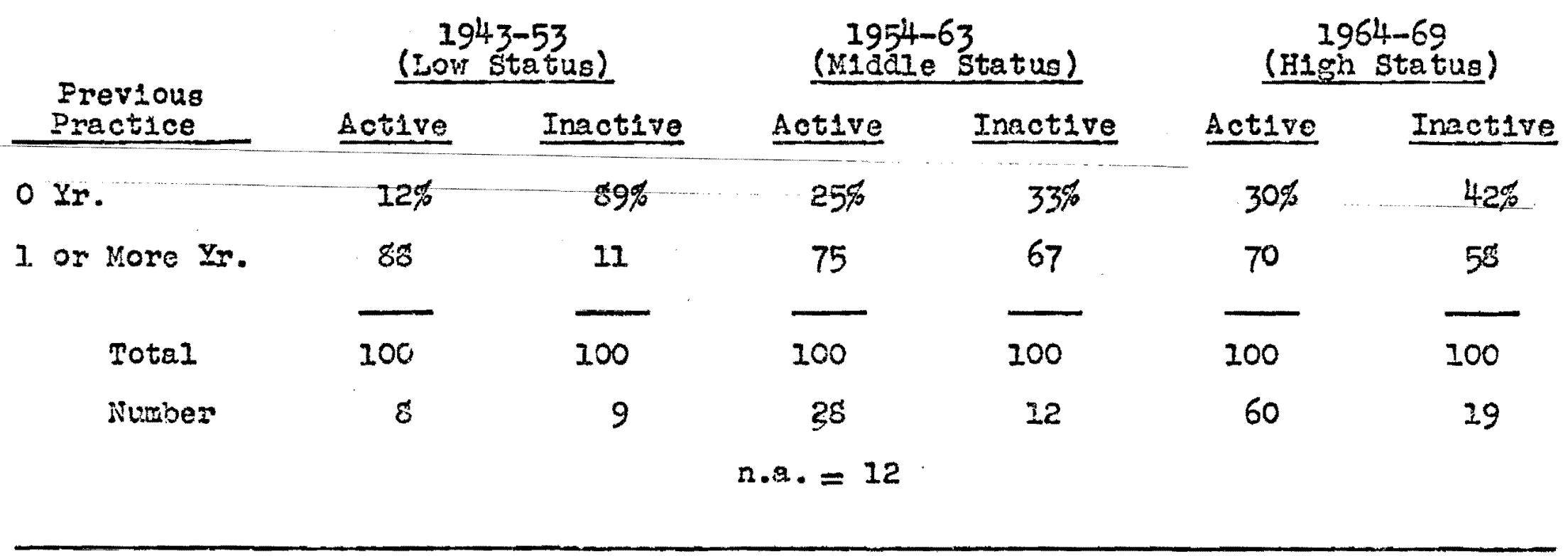


entering Kaisor decreased. The detailed findings are listed below:

1. As the status of Kalser has increased, the percentage of domestic recruits (who have high ascribed status) has decreased, whlle the percentage of fozelgn recrusts (who have low ascribed status) has increased.

2. Among active staff, as the status of Kalser has increased, the percentage of Kal ser recruit a who have been in practice one or more years (1.e., who have high ascribed status) has decreased, while the percentage of physiclans who have never been in practice (1.e., who have low ascribed status) has increased.

\section{SUMMARY: HYPOTHESIS ONE}

Earlier, in summarizing the firet part of the findings on hypothesis one (1n which the dopendent variable is the achieved status of physiclans entering Kaiser), we notod that the findings were inconalstent and inconclusdve. When prestige of medical school was used as an indicator for achleved status, an inverse relationship was found between the status of Keiser and the status of 1 ts recruits. However, when prestige of hospltals of internship and roaldency was used, a dreot relationship was found.

In contrast, the findings on the second part of hypotheats one (where ascribed status is the dependent variable) are consfstent. They show that os the status of Kaiser has Inoreased, the ascribed status of physlcians entering Kaiser has deoreased. In other vords, these variables appear to be

inssing from the date on active atarf, these data are not quite corplete. 
Inversely rather thon directiy related. On the whole, a varlety of evidonce has beer presented supporting the conclusion that the status of physiclans entering Kalser has decreased while the status of Keloer has 1ncreased. Th1s includes data mich use three diverese indicators for the status of physicians: prestige of medical sohool (which was based on an informant ranking), nationallty, and length of practice. It also includes data where four different controls are placed on the flrst hypothesis.

In contrast, there 18 little ovldence showing that the status of physlcians entering Kaloer has increased. It Involves two indicators for statue, prestige of references and prestige of hospitals of internship and rosidency, which are essentially simller in that they are both based on the AMA rating of teaching hospitals.

Whereas the findings egaingt the first hypothesis aro based on three diverse indicators for status, the findings for the flrst hypothesis are based on only one kind of indicator. In other words, the former set of data is more heterogeneous than the latter set of data. Therefore, it appears that the first hypothesis of this study should be rejected. 
CHAPTER IV

\section{FINDINGS: POSITIONS OCCUPIED BY DOCTORS}

\section{PRIOR TO ENTERING KAISER}

In this chapter data on the second hypothesis of this otudy n11. be presented and discuesed. We will alscover that there are olightly more findings against this hypothes1s than for 1 and that there is no alscernable pattern to the positive and negative findings. As a result, wo w1.l. Ind it afficult to dran any general conclusions about the circumstances, if any, under which this hypothesis is successful. It will also be difficult to draw any definite conclusions as to why the findings are so highly inconsistent. Pexhaps some of the Indicators vere poor; perhaps it would have helped to use contrcla. In the last eection or this chapter, we will discuss each of these conjectures.

The second hypothesis of this study is as follows:

As the status (rank) of Kaiser increases, high status recrults will less frequently come from statuses (positions) with intrinsio rewards sinflar to those found in Kalser.

Indicators were needed for the status of Kalser, the status of physicians, and positions offering lntrinsic rewards similar to those found in Kalser. The Indicators for the 
status of Kalser have already been discuesed. ${ }^{1}$ Prestlge of medical. school was chosen as an 1ndicator for the status of physiclans instead of prestige of references or prestige of hospitals of internship and residency. As alscussed earlier, the data on the flrst indicator are more completo than the data on el ther of the other two indicators.?

Before indicators for positions with intrinsic rewards similar to Kalser's could be chosen, the intrinsic rewards assoclated with an active staff position in Kalser had to be 1dentifled. Five such rewards are the opportunities for 1) a more scientific practice, 2) a change, 3) more education, 4) easier access to faclitties, and 5) living in the West. Given these intrinsic revards of Kaiser, 1t was possible to genorate five predictions from the second hypothes18. Each of these predictions is distinguished by its dependent variable, which consists of one of five types of positions defined by the intrinstc revard of each.

Indicators were then sought for five typee of positions with intrinslc rewaris aimiler to Kalser's. Two ind1cators vere found for positions offering the opportunity for a more scientific practice; two indicators were also found for positions offering the opportunity for trore education. Three were found for positions offering the opportunity for a change. One indicator was found for positions offering egsier access to facilities; one was also found for a 
position offering the opporiunity to livo in the West. Thus, although only flve predletione vere generated frow the second hypothes1s, nine indicatora were identifled for its Independent variable.

Discussion will kegin with the findings which support the second hypothesis. These Iindings concern two out of the flve prealctions which were generated from this bypothesie. These two predictions pertain to physicians who entered Kaleer from positiong offering the opportunity for a more scientific practice and from positions offering the opportunity for a change.

It must be noted that in ali but one of the tables in this chopter at least seven cases are missing from the flrst time period because relevant data on these physlclans were not avallable. In some tables the total number of casea missing is higher. This occurs elther because information is missing on many physicians or because the categories in the table do not apply to the entlre universe of Kalser physicians.

\section{DATA FOR HYPOTHESIS THO}

Positions Offering the Ooportunity for a More Sclent1ric Practice

Firat Indicator. One of the intrinsic rewards of Kalser is the opportunity to provlde more sclentifle care. The first indicator for a position providing similar rewaras 
is previous position emphasizing the sclentiric rather then clinical aspects of care. Table XVIII shows that as the status of Kalser has 1ncreased, high statis recrults have less frequently come from positions with scientiflo and mixed oclentific-clinical orlentations, wile they have more frequently come from position with clinical orientations. As hypothesized, high status recrults have decreasingly como from positions with intrinsio rewards similar to Kalser's. Second Indicator. The second indicator for positions offering tho opportunity to practice more sclentiflcally 18 epecialty or scientific society memberships. Agein, the findings support the second hypothesis (Table XIX). As the status of Kalser has increased, the percentage of high status physiclans entering Kalser with one or more epeclalty or sclontiflo soclety memberships has decreased, while the percentage without eny such memberships has increased. In other words, the percentage of h1gh status recruits who have occupled positions with intringlo rewards similar to Kalser's has decreased over tlme. In sum, the second hypothesis is supported by rindings involving both indicators for positions which, like Kalser, offer the opportunity for a more scientipic practice.

Positions of fering the Ooportunity for a Change

Elrst Indicator. Entrance into Kaiser involves tho intrinsic reward opportunity for a obange. A series of positions characterized by the same revard is a caveer of 
TABLE XVITI

SCIENTIFIC/CLINICAL CRIENTATION OF PREVIOUS POSITION

BY TIME OF ENTRY TMTO KAISER AMONG

HIGH STATUS PHYSICINNS

(Por cent)

Perlod and Status of Ka1ser

Orientation

of Previous

Pogition

Clinical ${ }^{a}$

1943-53

(Low Status)

$10 \%$

8clentificC].Inical ${ }^{b}$

sclentilic $c^{\circ}$

Total

Nusaber
80

10

100

10

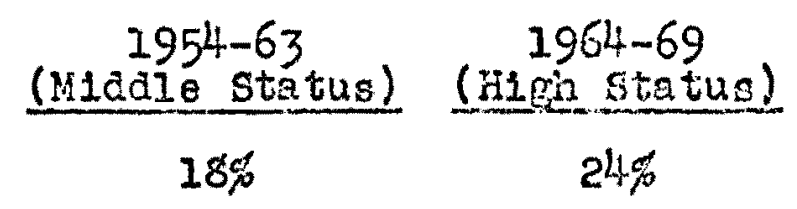

64

60

18

16

100

100

22

38

$$
\text { n.a. }=7
$$

apreviolis positions with clinical orientations to care include the G.P., military doctor, public health physician, physician in industrial or insurance medicine, and the adininistrator.

bprevious positions with eclent1fic-clinical orientetions to care ineluae the specialist in private practice, hospital practitioner, private asaistant, intern, resident, and post-graduate student studying clinloal practice.

CPrevioue positions with sclentiric orlentations to care include the group practitioner, teacher, researcher, and the post-graduate student doing rescarch. 
TABLE XIX

SOIENTIFIC AND SPECIALTY SOCIETY MEMBERSHIPS BY TIME OF ENTRY INTO KAISER AMONG HIGH STATUS PHYSICIANS

\section{(Per cent)}

\section{Perlod and Status of Ka1ser}

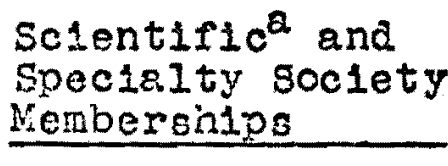

0

2 or Nore

Total

Number

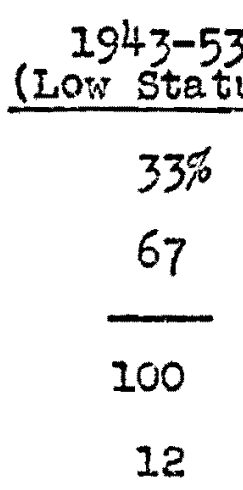

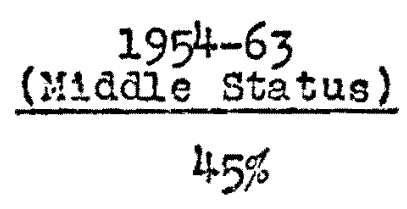

55

100

20

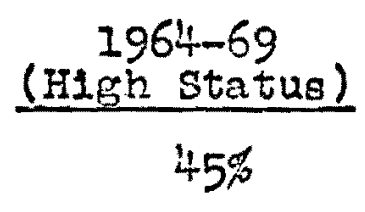

55

100

29

n.a. $=16$

a Examples of scientifle professional societies are the following: the American Assoclation for the Advancement of Sclence, American Soclety for Cinical Research, and the Mayo Foundation for Medical Education and Research. 
changes in location of practice. Table XX gummarizes the findings relevant to this indicator for positions offering the opportunity for a change. As the statug of Ka1ser increases, the percentage of high status recrults who bave changed the location of their practice one or more t1mes decreases; in contrast the percentage who have never moved their practices increases. In other words, high statui physlclans are less frequently entering Kalber from careers Involving intrinsic rewards similar to Kaiser's.

Second Indicator. Another 1ndicator for positions offering the opportunity for a change is a career involving one or more changes in specialty. Table $x \times$ reveals that as the status of Kalaer has increased, the percentage of high status recrults who have changed their spectalties one or more times has decreased, wh1le the percentage who have never made such a change has increased. Thus, high otatus recruits have less frequently come from careers involving intrinsic rewards olmilar to Kalser's.

Third Inalcator. A career characterized by changes in activities is yet another indicator for posftions offering the opportunjty for a change. In contrast to the f1rst two Indicators for such positions, this one ylelded negativo findings. Table XXII reveals that as the status of Kalser has increased, the percentage of high status physlcteng entering Ka1ser who have engaged in two or zore alfferent types of ectivity since completion of thelv residency 
TABLE XX

CHANGES IN LOCATION OF PRACTICE BY TIME OF ENTRY INTO KAISER AMONG HIGH STATUS PHXSICIANS

(Per cent)

\section{Per1od and Statue of Kalser}

\section{Jhanges in Location of Fractice}

0

1 or Nore

Total

Number

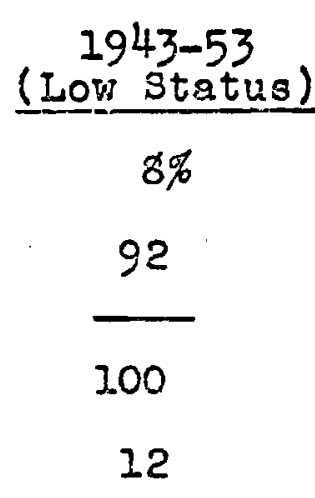

$\frac{\begin{array}{c}1954-63 \\ \text { (M1ddie Status) }\end{array}}{50 \%}$

100

16

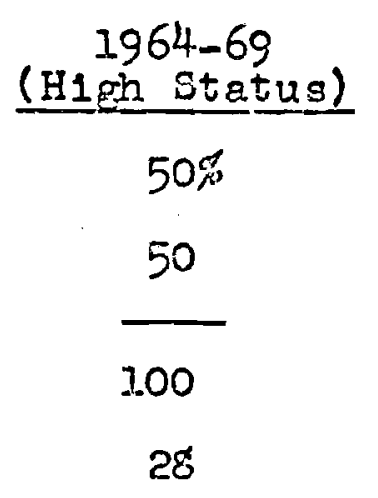

n.a. $=21^{a}$

a The cases of no information are high not only because of missing information but also because some physlclans enter Kalser who have not yet begun to pract 1 ce and a. a consequence have never had the opportunity to change the location of thelr practice. 
TABLE XXI

CHANGES IN SPECIALTY BY TIAE OF ENTRY INTO KAISER AMONG HICH SMTUS PHYSICIANS

(Per cent)

\begin{tabular}{|c|c|c|c|}
\hline \multirow[b]{2}{*}{$\begin{array}{l}\text { Changes in } \\
\text { Specialty }\end{array}$} & \multicolumn{3}{|c|}{ Perlod and status of Kalser } \\
\hline & $\begin{array}{c}1943-53 \\
\text { (Low status) } \\
\end{array}$ & $\begin{array}{c}1954-63 \\
\text { (Middie status) } \\
\end{array}$ & $\begin{array}{c}1964-69 \\
\text { (High stetus) }\end{array}$ \\
\hline 0 & $60.0 \%$ & $68.2 \%$ & $68.4 \%$ \\
\hline 1 or More & 40.0 & 31.8 & 31.6 \\
\hline Totel & 100.0 & 100.0 & 100.0 \\
\hline Number & 10 & 22 & 38 \\
\hline & n.a. & & \\
\hline
\end{tabular}

TABLE XXXI

CHANGES IN ACTIVITIES BY TIME OF ENTRY INTO KAISER AMONG HICH STATUS PHYSICIANS

(Per cent)

Perlod and Status of Ka1ger

Changes 1n $1943-53 \quad 1954-63 \quad 1964-69$ Activities (Low Status) (Midale scatus) (High status)

0

1 or More

Total

Number

$$
70 \%
$$

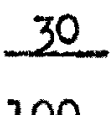

10
$46 \%$

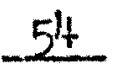

100

22
$47 \%$

53.

100

38

$$
\text { n.a. }=7
$$

ADifferent kinds of activity include the following: private practice, group practice, hospltal practice, practice in the publ 1c heal.th servica or Veterans Adminlstration, practice in the armed forces, teaching, research, postgraduate training, practice as a private assistant, and administrotive medicine. 
training has increased, while the percentage who have engaged in only one type cf activity sjnce the1r residency has decreased. Contrary to expectation, high status physiclans have nore frequently entered Ka1ser from careers involving intrinslc rewards similas to Kelser's.

In oum, we find that the second hypothesis is oupported by two out of three inalcatorg for positions or sets of positiong which, like Ksiser, offer the opportunity for a change. On the balance, we conclude that these sindinge support the socond hypothes1.s.

\section{gummaxy}

The flndings which support the second hypothesis are 11sted below. They include both indicatoso for position offering the opportunity for a more sclentifle practice but only two of the three indicators for positions offering the opportunity for a change.

1) As the status of Kaleer Increased over t1me, high otatus physiclens less frequently entered Kalser from positiong emphesizing the scientific and sclentiflcclinical a epects of care; they more frequentiy entered Kalser from positiong emphasizing the cinical aspects of care.

2) As the stetus of Kalser has increased, the percentage of high status recruits with memberships in scientific or epocinlty societies has decreased, while the percentige without such mernoerships has increased.

3) As the status of Ka1ser hes increasei, high status physj.clans who have changea the location of the1r practice have less rrequently entered helser; those who have never made auch a change have ore frequently enterea Kaleer. 
4) As the otglus of Ka1ser increased, the percentage of high status recruits who had changed thelr specialty decreased, whlle the pereentage of recruits who had nover made such a chonge increased.

In general, as the atatus of Kalser inoreased, high status phyalcians lesa frequently entered Ka1ser fron pos1tions and careers whtch, like Kalser, offer opportunities for change and sclent1fic practice. The findings conflrm two of the flve predictions which were generatod from the second hypothesis.

\section{DATA AGAINSI HYPOTHESIS TWO}

The finding which fall to support the second hypothesis concern predictiong about physlclans tho entered Kalser from poestions offering opportunsties for more educetion, for easier access to facilsties, and for living in the West. All of the indicators for these positions consistently ylelded negative firdinge. These findings are sumarlzed below:

1) As the status of Kalser has Increased, high status physlolans with postgradus.te training have more frequently entered Ka1ser, whlle phyalclang without such training have less frequentiy entered Kaloer (Table XXIII).

2) As the status of Kalser has increased, the percontage of high status recruits who have had five or more years of training has increased, while the percentage who have had less tralning has docreased (Table XXIV).

3) As the status of Kalser has increased, high status physiclans have more frequently entered Kalser from careers in bureaucratic contexts; they have leas frequently come from caroers in private practice (Table $\mathrm{XXV})$. 


\section{TABLE XXIII}

POSTGRADUATE TRA INING BY TIME OF ENTRY INTO

KAISER AMONG HIGH STAPUS PHYSICIANS

(Fer cent)

Period and Status of Ka1ser

Postgraduate

Traintnga

$0 \mathrm{Yr}$.

$I$ or More $\mathrm{Yr}$.

Total

Number

$\begin{gathered}1943-53 \\ (\text { Low status }\end{gathered}$
$90 \%$
10
100
10

$$
\begin{gathered}
1954-63 \\
\text { (Msadie status) }
\end{gathered}
$$

$62 \%$

38

100

21

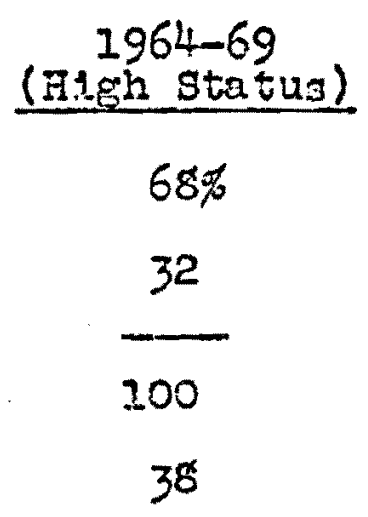

n.a. $=8$

apostgraduate tralning refors to medical training, excluding medical school, internship, and residency training. 
TABLE XXIV

LENGTY OF TRAINING BY TIME OF ENTRY INTO RAISER AMONG HIGH STATUS PHYICIANS

(Per cent)

\section{Perlod and Status of Ka1ser}

Length of

Traininga

$0-1+x \mathrm{rs}$.

5 or More' 'Yrs.

Total

Number

$\begin{gathered}1943-53 \\ \text { (Low Status) }\end{gathered}$
$\frac{70 \%}{30}$
100
10

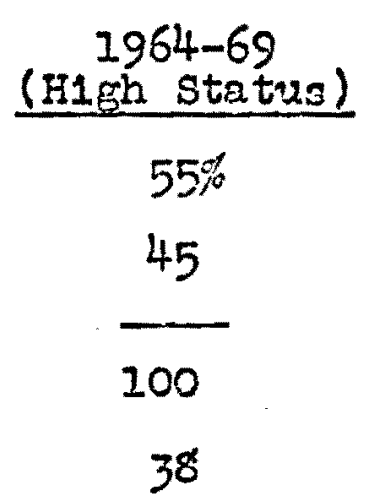

n.a. $=7$

Mength of training rofors to the total number of rears spont in internahip, residency, and postgraduate training. 
TABLE XXV

BUREAUCRATIC/NONBUREAUCRATIC CONTEXT OF CAREER BY TIME OF ENTRY INTO KAISER AMONG HIGH STATUS PHYSICIANS

(Per cent)

\section{Perlod and Status of Ka1ser}

\section{Coniext or Career}

Nonbureaucrat1 $\mathrm{c}^{\mathrm{a}}$

Bureaucrat $1 c^{b}$

Total

Number

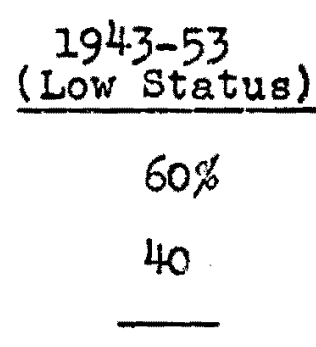

100

5
$1954-63$

(Midale Status)

$47 \%$

53

1.00

15

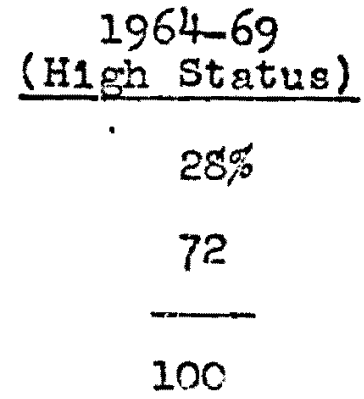

25

$$
\text { n.a. }=32^{\mathrm{c}}
$$

${ }^{a_{C a r e e r e}} 1 \mathrm{n}$ nonbureaucratic contexts refer to careers in private practice.

bareers in bureaucratio contexts refer to careers spent in one or more positions whers faclities are centralized and income is recelved in the form of a salary. Training and m1litary service are not considered to be part of a physiclan's career.

There is a high number of cases of no information because they jnclude 25 physicians who entered Kaiser just after completing their training and militery service. 
4) As the gtatus of Kalser has increased, high status recruits have more frequentis come from medical schools In the North Central and Vestern states, whereas they have less frecuently come from schools in the Northeast. The percentage coming from the south has varled incongistently over time. In sum, although in the last time period most high stetus recruits came from North Central sohools, over time the location of recrults' schools has varled from East to West (Table XXVI).

In sum, as the atatus of Ka1eer has increased, high status physlclans have more frequently entered Kalser from positions and careers wilch, 11he Kalser, offer opportunitles for more education, for easler accese to facllities, and for living in the West. These findings fail to supports three of the flve predictions whlch were generated from the second hypothesis.

\section{DISCUSSION}

The findings both for and against the second hypothosio have now been presented in full. The evidence confirng tro of the prealctions which were generated from this hypothe日1s, but fails to confirm three others. In other words, the rindings are inconsistent.

Furthermore, we have not been able to discern any pattern to the positive and negative findings, which would allow us to account for the success of certain predictions and the lack of success of others. Although a varlety of conclugions might havo been drawn from the data, we lack the evidence which would be needed to choose anong them. Thus, we do not know whether to accept all the finding's as valid or 
TABLE XXVI

REGIONL IOCATION OF MEDTCAL SCHOOL BY TIME OF ENTRY INTO KAISER AHONG HIGH STATUS PHYSICIANS

(Per cent)

Period and status or Kaisor

Location of
Medjcal School
(Lov Statu

$1954-63$

$1964-69$

Northeast

$59 \%$

$37 \%$

$20 \%$

South

6

16

6

North Coniral

29

31

62

West

$\frac{6}{100}$

16

12

Total

17

200

100

Number

19

34

$$
\text { n.e. }=7^{b}
$$

arh1s regional breakdown of the United States comes from the following source: U. S, Bureal of the Censtis, U. S. Census of the Population, 1960: Chargeteristics of the Population, rPt. A, Number of Inhabitants Thaghington, D. C.: J. S. Government Printing Office, 1961), I, 82.

$b_{\text {The }}$ seven cases of migsing information represent high otatus physicians from forelgn medical schools.

only some of them, that is, only the positive or only the negative rindings. In other worde, the findings are inconclusive.

Although we are unable to draw any general conclusiong as to why the findinge are inconsistent, we can offer sug-gestions about particular cases of negative findings. In 
the following discussion, we rll speculate about ways to account for some of the flndings agalnst the second hypothes1s. Tro possible sources of error will be alscussed:

1) the validity of Indicators used in certain predictions and 2) the absence of controls on exogenous factors which might be interrelated whth the varicibles used in certain predictions.

Is the Opportunity for More Education an Intrins1c Revard of Ka1ser?

Both indicators for positions offering the opportunity for more education, 1.e., postgraduate student and a career involving extensive training, ylelded negalive findings. One resson may be that the opportunity for more education 18 an incentive for mobility for only certain kinds of physicians.

Two types of situations can be suggeted in which the incentive value of thie reward would vary. First, the opportunity for more education may be en important intrinsic reward only for piysiclans who want to take thelr American Spectalty Board Exams in order to obtain catification but who first need to do additional. study. Second, it may be important only to low status physicians entering Kalser but not to high statuo physiciene. For any given set of physiclans, it may be 1mportant to see the opportunity for more education provided by Kalser as one of a se of altematives. For Instance, although Kalser may be sble to offer better 
educational opportunities then private practice, it probably offerg poorer opportunities than teaching or research. Suppose that many high gtatus physictans wino apply for positions in Kalser have a cholce between practicing in Ka1ser and teaching or doing research. Then the opportunity for more education would not be a agniflcant intringle revara of Kaiser from their point of $v 1 e *$, although $1 \hat{t}$ might be from the point of vlew of a low status recruit.

In sum, it has been suggested that the opportunity for more education is an incentive for mobility for only certain kinds of physiclans. If this assertion $1 \mathrm{~s}$ correct, then $1 t$ may account for the negative findings which were based on the assumption that the opportunity for more education is an intrinsic revard for all physicians.

The Changing Specialty Composition of Ka1ser: A Needed Control?

The prediction concerning phyglcians tho enter Kalaer from positions offering the opportualty for more educetion may have yieided negat1vo findings becauso lioportant exogenous variabies were not controlled. Rayack states that, "The average length of training for doctors after completion of medical school has increased from about two years in Iglo to about three-and-one-half years in 1959.3 Furthermore,

3elton Rayack, Professional Pover and American Medic1ne: The Economica of the American Hedical Assoctation (cleveland: The World pubilahing conpang, 1967), p. 112. 
he argues that this increase is a product or the trend toward speclalization. If his analysis is correct, then it indlcates the need for a control on the changing specialty composition of Kalser over tima.

Perhaps the high status phyolcians entering Kaloer have increasingly been specialists in spectalties where the average length of training is long. This vould indicate that the increase in Kaiser recruits with extensive training is due to changes in the specialty compostition of Kaiser. Thus, a control on this exogenous variable is needed to find out whether within each grow of apeciallate (each group beIng defined by the average length of training of physfctang within 1t) high status physiclans have more frequently entered Kalser with more or less training.

The Changing Composition of Positions in the Medical Prolession: A Heeded Control?

The prediction concerning physlcians who enter Kaloer frow positions offering easier accoss to facilities yleldea negative findings. The indicator for such positions was a career in a bureaucratic context. A possible reason for thece negative findings is that no controle vere placed on the changing composition of posttions in tre medical profession.

Data found in kayack reveal the necossty for guch a control. Rayack documents wat he calls the "organtzational revolution in modical practice." He states that, "As a 
result of these developnents, the doctor bas become an organ1zation man, 4 and cltee the gronth of both group and hospital practice as evidence. Hia data reveal the increasing employment of physiclang in other kinds of bureaucratic contexts as vell: Whlle the percentage of physiclans who were interns, residents, or full-time hospltal staff increased from 6.2 per cent in 1931 to 26.5 per cent in 1962 , the porcentage in teaching, administration, industry, government service, and retirement increased from 7.9 to 19.0 per cent. 5

In sum, it appears that the avallabilfty of position in bureaucrat1c contexts has increaged and thus that the composition of position in the mealcal profession has changed. The finding that the percentage of high status physlclans entering Kalecr from careers in ureaucratic contexts has increaged over time may be an effect of the changing composition of positions in the medical profession. Therefore, a control is needed on this exogenous variable. The changing composition of positions in the medical profession may have affected another finding in the present atudy. The flnding 1 s that of an increase in the percentage of high status physiclans entering Kaiser who have changed activities one or more times since completing thelr residency training. A change in activity involwes elther a

$$
\text { 4Ibid., pp. 39-40. } \quad \text { 5Ib1d., p. } 46
$$


chonge between different bureaciatic contexts of activity, weh as from teaching to group practice, or a change between bureaucratic and nonbureaucratic contexts, such as from private to hospltal practice. (See Table XXII for more deta1l.) If the avallability of positions in bureaucratic contexts has increased, then it is likely that there has been a concomltant increase in the opportunity to change activities. Accordingly, the increase in the percentage of high status phyolclans entering Kalser tho have changed activities one or more times may reflect this increased opportunity for change rather than a difference in the kind of physictan who enters Ka1ser. Aga in, a control on the changing composition of positions in the medical profession 1 s needed.

\section{Suramary}

Since no overall pattern could be discerned in the findings for and against the cacond hypothesie, it remains unclear why certain predictions generated from this hypothe日1s were successfu]. and others fiere nat. Therefore, our discuesion of the findinge involved speculation about particular cases rather than a general interpretation. Problens of invalid indicators and extraneous unconirolled variables were focused upon. Suggestions were nade as to the ways in which they could have influenced some of the findings against the second hypothesis: 
CHAFTER V

CONCLUSIONS

In retroupect, the nature of the present study can beat be described as exploratory research. The 11terature of meácal sociology served a a baste for defining a problen concerning prepald group practice which, although worthy of soclological 1nvestigation, had never been btudied before. A theory was then selected to deal with this problem, hypotheses were genorated, a design was chosen, and data were collected.

However, prior to data collection, no preliminary examination was made of aata relevant to the problen. Accoraingly, it is not surprising that by the time the study had been completed, many rew laeas for a bettor researah design and for alternative hypotheses had energed. Thus, the fruits of the present study undarline the need for exploratory reserrch. The present atudy with its generelly inconclusive and negative findinge 1 of value only insofar as it oan be used to design an alternative study of prepaid group health plans. 
I. SUMMAFY OF THE STUDY

Problem

As a result of the AMA's opposition to prepald group health plans, it 18 likely that these plans experienced diffloultes in recruitment after they wore established. Ag opposition was relaxed, these difficulties probably disappeared. Assuming that changes in the soclel characteristics of physiolans enterling prepala group health plano reflected changes in recrultment probloms, then it is likely that the kinds of physiclans who enter these plans have sy3tematically varied over time.

Such variation prosents a problem for research, namely, to inquire into the direction of and reasons for the variation. The task of the present thesis was to "solve" this problem.

Conceptualization of the Problem

Although previous studies had not done so, the entrance of physiclans into prepald group health plang was conceptualized as mobllity between different contexts of work (c.g., solo practlce, prepald group practice, medical schools, hospltals, the public health aervice, etc.). The theorotical justirication for this conceptualization was that the definition of moblilty, "movement of persons... through the 
social structure, "I was broad enough to include movement between different contexts of work.

The empirical justification cane from a study by Wilerisky. H1s factor analysis of mobility showed that the change between self-employment and working for an empjoyer (or vice versa) represented ore almension of moblity. 2 These findings suggested that the movement of physlclans into solo versus prepald group practice involves one dimension of moblilty. For these reasons, it appeared legitimate to conceptualize the entrance of physiclans into prepasd group health plans in terms of mobility.

Theory and Hypotheses

The topic of this study was the longltudinal vaisetior: in the social characterlstics of physicians entering prepaid group health plans. Given this tople, the research object1ves were to generate a set of hypotheses to describe and partiseliy account for changes in the types of physiclans who have entered prepald group health plans over time. Blau's exchange theory, particularly those sections on mobility and recruitment, proved to be the most frustful source of

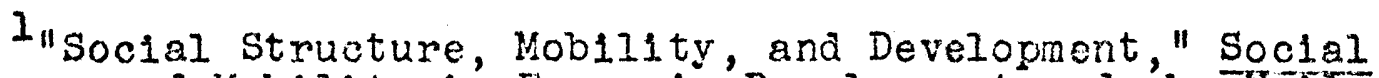
Structure and Mob1lity in Economic Development, ed. by NeII J. Smelser and Seyinour Hartin Lipset Tobleago: Aldine Publishing Company, 1966), p. 2.

2Harold L. Wilensky, "Neosures ond Efiects of Mob1l1ty," Social Structure and Mopility, ed. Smelser and Lipset, pp. $110-11]$. 
hypothoses for this study. 3

One of the basic propositions of exchange theory is that individuals and collectivities follow the most profitable courses of action. Profit is defined in terms of the balance between rewards and costs (1.e., resources gained and lost). Rewards can be of two basic types-extrinsic and intrinsic. Extrinsic rewards, e.g., money, can be used in any situation; the benefits of intrinsio rewards, e.g., social acceptance, can be gained in only one given situation. The extrinsic rewards associated with a given position or collectivity define the status, or rank, of that position or collectivity.

The firat hypothesis of this study was based on two propositions which were generatea fron Blau's alscussion or the relationship of extrinsic rewards to boblity and recruitment. Blau etates that for a given individual nobilIty 18 depondent on his having the opportunity to recelve higher rewards. Such opportunities depend on the status of the individual before mob1lity: high status gives an Individual a greater opportunity than elther midale or low status. The following proposition is suggested: Opportunities for higher rewards lead to moblilty of high status individuals.

3peter M. BIau, Excherige und Power in Soc1al L1fe (New York: John Wiley \& Sons, Iro., 1964), pp. 294-301. Peter. M. Blau, "The Floy of Occupational Supply and Recruitment," ASR, XXX (1965), $475-490$. 
Blau also states that for a given collectivity the allocation of more resources to recruitment depends on successiul competition. Since successful competition involves an increase in status for a collectivity, the following proposition 1s suggested: As the stotus of a collectivity increases, the rewards which it offers recrults will also increase.

This proposition together with the preceding one suggested the following hypothesis:

As the status (rank) of prepald group health plans increases, the status (rank) of physicions entering these plans will increase.

This hypothesis was resined by distinguishing the various criteria, 1.e., achievenent and ascription, which govern the distribution of extrinsic rewards:

As the status (rank) of prepald group plans increases, a) the achieved status of physicians entering these plans w1ll increase and $b$ ) the ascribed status of these phystcians will increase.

Intrinsic as well as extrinstc rewards may serve as incentives for mobility. According to Blau, intrinsic rewards vary in the degree to which they serve as incentives for moblilty, depending on the experience which an individual has had with these rewards in previous statuses (positions). Accordingly, one might expect that the kinde of intrinsic rewards recelved in previous statuses affect the kinds of individuals who are moblie. Assuring that both intrinsic and extrinsic rewards interact in influencing mobility, the following hypothesis is suggestec: 
As the status (rark) of prepald group health plans increases, high status recruits will leas frequently come from statuses (social positions) with intrinsic rewards similar to those found in prepald group plans.

Source of Data and Degign

The main source of data for the present study was the personnel records of the Portiand Kaiser Foundation Health Plan. These records included applications for staff membership, a few letters of roference, coples of personnel advertisements which were placed in the medical journals, job inquiries, and an official schedule of starting salariea by specialty. Two minor sources of data used to supplement the Information in the records were the AMA's Agerican Medical Directory and Directory of Approved Internships and Rea dencies.

The design for this research was a longltudinel case study. Data were presentea on the unfverse of physiclans who had practiced as full-time, salaried stafi in Kaleer at any time since 1945 when Kaiser was first opened to the public. This incluãed a I $T$ physicians who entered kalser before 1945 when the Health Plan was being run on a strictly war-time basis, and this excluded physicians who practiced in Kalser only during the war years. Since the kinds of variables which could be extracted from the records were nominal and ordinal variables, cross-tabulation was usod in the presentation and analysis of the findings, and gamma wes used as a measure of association between ordinal variables. 


\section{Indicators}

Indicators were needed for four variables: the etatus of Kalser, the achleved status of physlclans, the ascribed status of physiciens, and positions with intrinsic rewards similar to those of Kalser. Because of the small size of the universe of Kalser pnysicians $(N=148)$, $1 \tau$ seemed practical to look at variations in the status of Kaleer in terms of low, medium, and high statide perlods. Thus, indicetors were needed to show not only the airection but also the tinIng of changes in the etatus of Kaiser.

Two indicators were used to determine the alrection of changes in the status of Kelser over time: 1) the ratio of unacoepted applicants to staff position openings in Kalser and 2) a comparison of the rates of increase in the starting salaries of Kalser speciallsts to the rates of increase in the incomes of self-employed physlclans under sixty-rive. The data on both revealed that the status of Kalser had inoressed over time. The tiaing of the changes in the status of Kalser was evident only from the second indicator since data on the first indicator were limited to the perlod from 1959 to 1969. Accoralngly, it was found thet during the perlod from 1943 through 1953 Xa1ser had low status: 1954-63 was a period of midale status; from 1964 through 1969 tho status of Kalser was high.

Two inalcators were used for the accribed status of physiclans and three were usod for their achieved etatus. 
The prestige of physicians' medical schools, of their hospitals of internship and residency, and of their references were used as indicators for achleved status. The prestige of medical schools was determined from informant ratings of the schools. An crefcial AMA rating or hospitels found in the Directory of Approved Internsh1ps and Residencies was used as a measure for the prestige of hospitals of internship and residency. The prestige of references was inforred from the prestige of their organizational affiliations. Again, the AMA rating of hospitalo was used as a basis for determining the prestige of these organizations.

Indicators for positions with intrinsic revards $51 \mathrm{~s} s . \mathrm{s}$ to those of Kalser vere found by first laentifying intingie rewards associated with a postion $1 r$ Kalser and then by ldentifying positions of ering oimllar rewaras. Accordingiy, the rollowing indicators vere selected:

$$
\begin{gathered}
\text { Intrinste Rewards } \\
\text { of Kalse? }
\end{gathered}
$$

Oprortunsty for more educetion Opportumity to provide more
sclentific cope

\section{Opportunity for more con- venient access to \\ racilities}

Opportunity to Isve in the West \begin{tabular}{l} 
Positions Offering \\
Similar Rewards \\
\hline
\end{tabular}

Postgraduate student

Career involving extensive training

Specialty or scientirlo society memberships

Previous position emphasizing scientiflc rather than clinical aspects or care

Career in bureaucratic cont ext

Medical school student in the West 
Intrinsic Rewards

of Kaiser

Opportunity for a change
Positions Offering

Similar Rewards

Career of changes in specialties

Career of changes in location of practios

Careex of changes in activities

\section{Findings}

The evidence for the flrst hypothesis was generally negative. It indicated that although the gtatus of Kaiser had increased over the yeare, the status of physlcians entering Kaiser had decreased. This conclusion was reached on the basis of findings using prestige of medical school as an indicator for achleved status as well as findings using nationality and length of practice as indicators for ascribed status. It was further supported when active/inactive staff stetus and length of practice were introduced as third factors. Both these controls served to reveal the limiting conditions of the orlginal reletionship. In revealing an independent effect on the status of Kalser recruits, controls on nationality and in-state/out-of-state location of mediar school also supported the original finding.

The findings using prestige of hospltals of internship and residency and prestige of references as indicators for achieved status showed that the status of pifysicians entering Kalser had increasod over the years. However, there are a number of reasons ror questioning the validity of these finalngs: I) None of these data apply to the whole universe 
of Kaiser physicians--from forty to seventy per cent of the cases from the first time persod are missing. 2) The discrepanoy between these findings and those just described may reflect the different methods used to rank medical schools and hospitals. 3) Based on three diverse types of indicators for status, the findings egainst the first hypothes1s appear more persuasive than the findings for the first hypothesis, which are based on only one kind of indicator.

The evidence for the second hypothees was inconclusive: 1t indicated that as the status of Kaiser incrcased, the percentage of high status recruits fros certain positions with intrinsic rewards slmilar to Kelaer's deoreesed, wherea the percentage from other positiong increased. H1gh status physlciono have less frequently entered Kaiser a) havIng hela positions emphosizing the scientirlo aspects of care, b) having memberships in scientific or specialty soclet1es, c) having changed the location of their prectico, and d) having changed thelx specialty. They have moro frequentiy entered Kaiser a) having had postgraduate train1ng, b) having had at least five years of training, c) havIng held jobs in bureeucratic contexts, d) having graduated from medical schools in the North Central and Western states, and e) having engaged in two or more different types of activities.

The only discernable pattern in these data is that among multiple indicators for positions offering a givon 
intringic reward, the findings are generally consistent. Nevertheless, no pattern which would allow us to account for the success and lack of success of indicators related to certain intrinalo revarde is apparent in the positive and negative findings. There appears to be no reason to suspect that elther the positive or the regetive findings are invalid. Furthermore, assuming that all the findings are valid, no theoretical explengiton is evident for these seemingly contradictory results. In sum, the findings for the second hypothesis are inconclustve, and they will not be discussed further. However, orne suggestions will be made as to the theoretical significance of the findings pertaining to the firat bypothesis.

\section{DISCUSSION}

It has bocome evident that the first hypothesis of this study must be rejected. However, it does not necessarily follow that Blau's theory of moblity nust bo abandoned. Perhaps the lack of success of this hypothesta 1s due not to 1nedequacies in Blau's theory but to the following factors. First, the hypotheses of this study represent much simplified versions of Blaw's theory. They poorly reflect the interrelationship of the factors which in theory influence moblitty. Second, the emplricel problem with which this etudy deals, 1.e., variations over time In the types of physiclans entering prepald group prectice, 
might have been poorly conceptualized. In light of these two potential sources of error, the conclusion is not warranted that the use of exchange theory in the context of mobility between different work contexts is inappropxiate. The findings of this study do not necessarily cali for the rejection of Blau's theory of mobility.

If Blau's theory of moblilty need not be rejected, then perhaps exchange theory can be used to suggest a factor explaining the unexpected relationohip found between the etatus of Kaisor and the status of its recrults. It w1Il be argued that such on explanetory factor 1 s the intrinsic reward involving the opportunity to participate in an innovative form of medical practice.

It was stated earlier that in general BIau consiaers extrinsic rewards to be more important incentives for moblity than intrinelc rewerds. However, this 1mplies that in certain situations intrineic rewards are more Important. Perhaps such a situation was the opening of the Kaiser Health Plan in Portland, Inasrach as Kalser was one of the first prepald group health plans in the United States and claimed to be an innovative form of medical practice.

Assume that the opportunity to participate in an Innovative form of medicel practice was the most importent incentive for mobility initially of exea by Kaiser. Then the following question arises: what kinds of experiences in 
other positions would lead physiclens to find the opportunlty to innovate rewarding? Pexhaps, as Homans argues, 1t 18 the experience of high status. 4 Ir 80 , then the early importance of the opportunity to innovate in the history of Kalser would account for the high percentage of high status physicians who entered Kaiser frow 1943 through 1953.

Like the extrinsic rewards cffered by Kaiser, the intrinsic rewards of Kaiser may havo changed over the years. If at one time Kalser ceased to provide the opportunity to innovate, then this would account for the decreasing status of physicians entering Kaiser after 1953.

Up to this point we have argued that changes in the intrinsic rewards of Kalser are related to chenges in the status of physicians entering Kaiser. It olso seens plausible to argue that certain intrinsic revards, namely, those involved in the fulfillment of the goals of an organization, are relatod to the extrinsic rewards offered by the organization. For instance, if the primary oporating goel of Kalser were low cost medical care for the patient, then it 1s I1kely that profits made by the organization would be used to cut the patient's medical expenses. However, if the goal were to make the income of Health Plan physic1ans

4George Caspar Homans, Soc1al Behavior: Its Elementary Forms (New York: Harcourt, Brace \& Worid, Inc., 196I), p. 352 . 
competitive with those of private practitioners, then profits would probably be used to increase physicians' salaries and bonuses.

Fror this example it is clear that intrinsio rewardo associated with the fuiflilment of the goals of an orgen1zation may be interrelated with the extrinsic rewards offered by the organization. If the opportunity to innovate involved the opportunity to place the interest of the patient above the interest of the physician, then 1t seems reasonable to suggest the following hypothesis: As the intrinsic rewards of Kalser changed, the extrinsic rewards also changed such that the starting salaries of pered recrults were ralsed.

In sum, the following interrelationship among tho intrinsic rewards of Kalser, its status, and the status of its recruits has been suggested:

change in intringic rewards, i.e., opportunity to innovate

change in extrinsic

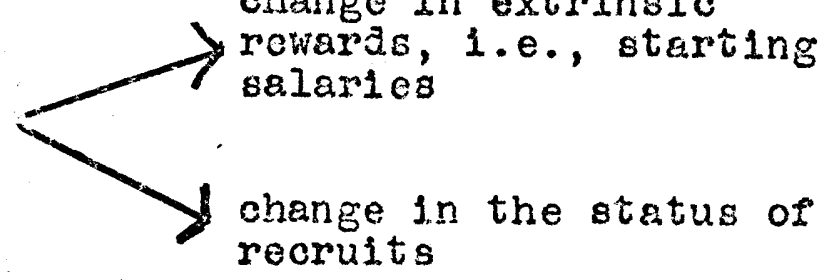

In other words, by revealing the spurlousness of the inverse relationship found between the status of Kalser and the status of 1 ta recruits, the factor of intrinsic rewards may serve to explain this relationship. 
III. SUGGESTIONS FOR FUTURE RESFARCH

Because of the negative, inconclusive findings of the present study, further research into the problem of changes in the types of physicians who entor prepald group practice is needed. If future research into this problem is to be more successful than the present study, the follontre suggestions must be heeded:

1) The design of such a study should include a control group of private practitioners. The findings of such a study would then be less tentative than the findings of the present study.

2) Multiple sources of data on physiclans should be used. For instance, curricula vitee, letters of reference, notes from telephone conversations, as well as appilcation forms coula be used to gain information on physicians in prepald group health plans. This would lead to the discovery of the errors which are likely to be found in any given source of data and allow the researcher to deal with them.

3) Alternative indicators for physiclans' achieved status should be tried out, e.g., the prestige of a physician's preceptor, an index reflecting the average prestige of a physiclans' changing organizational affiliations, and an index based not only on the prestige of the institution where a Kaser applicant and his reference were colleagues but also on the rating givon the applicant by his referenco. In ligint of the contradictory results which were obtained from the varlety of indieators used in the present atudy, It seems that the alternative indioators suggested here might be more useful.

4) New hypotheses should be formulated, perhaps using intrinsic rewards as an independent variable. Hopefully, they wolld be supported by the evidence. 


\section{REEERENCES CITED}

Adams, Stewart. "Trends in Occupational Origins of Fhys1clans," ASR, XVIII (.953), 404-409.

American Medical Direotory: 1950. 18th ea. Chicago: American Meducal Ageodation, 1950.

Amerdcon Medical Directory: 1967. 24th ed. Chicago: American hedical Association, 1967.

Approved Internshipe and Rondencies in the United States 1948. Ontotgo: Merican Nedical Aesoctation, 1948.

Ben-Davia, J. "The Professional Role of the Phystcien in Bureaveratized Hedictne: A Study in Role Conflict," Human Reletsons, Xi (1958), 255-7!.

Blau, peter in. Exonange ena Power in Soc1al Iffe. Nev York: John Whiey \& Sons, Inc., 1964.

- "The Flow of Cocupational Supply and Recrult. ment, ASR, XXX (.2965), 475-90.

Colonbotos, John. "Soctel Ortgins and Ideology of Phyolc1ans: A Study of the Expects of Early Soclalization," Journal of Health and Soctal Behavior, $x$ (Waroh, 1969$), 36-29$.

Davis, Kingeley and Wilbert E. Mooro. "Some Principles of Stretirication," Class, Status, and Power: Soclal Stratifloation in Comparefire Persoective, ed. Reinhard Bendix end Seymour Martin Lipet. Znd od. New York: The Froe Press, 1966. po. 47-53.

Directory of Aporoved Internohips and Restaencies 1960. Hilcago: Arerican Medicaj Association, 1960.

Directory of Approved Internships and Residencies 1967-68. Chicago: American Vedical Association, 1967.

Faltermayor, Edmund K. "Better Care at Less Cost without Miraoles," Fortune, LXXXI (Jan., 1970), 80-83 ff. 
Fora, Amasa B. et al. The Doctor' a Perspective: Physiclans Viev their patients and practice. Cleveland: The Press of Case Western Reserve University, 1967.

Frelason, Ellot. Patients' Views of Medical Practice: A Study of Subscribers to a Prepald Medical Plan. New York: Russeli Sage Foundation, 1961 .

"Giant Group Practice Heada East," Medical Worla News, Nov. I, 1968, pp. 44-50.

Hal1, Oswald. "The Stages of a kedical Gareer," AJS, LIII $(1948), 327-36$. $24 \dot{3}-53$.

"Types of Medical Careers," AJs, LV (1949),

Homans, George Caspar. Soclal Behavior: Its Elementaxy Forms. New York: Harcourt, Brace d Wor Id, Inc., 1961.

Jordan, M. D., Edwin P. The Phyelcian and Group Practice. Ch1cago: The Year Book Publishers, Inc., 1958.

Lleberson, Stanley. "Ethnic Groups and the Practice of Mediolne," ASR, XXIII $(1958), 542-49$.

Molirath, Dennis C. "Perspective and Participation of Physicians in Prepala Group Pract1ce," ASR, XXVI $(1961), 596-609$.

McGinnis, Robert. "Randomization and Inference in Sociological Research," ASR, XXITI (1958), 408-414.

Merton, Robert K. and Allc o S. Kitt. "Comiributions to the Theory of Reference Group Behavior, "Studies in the Scope and Method of "The Amerlcan Soldier, "ed. Robert $R$. Mertón and Paul F. Lazarsfeld, pp. 40-105. Glencoe, Illinots: The Free Press, 1950.

Phyglcians' Earnings and Expenses: A Reprint of Articles

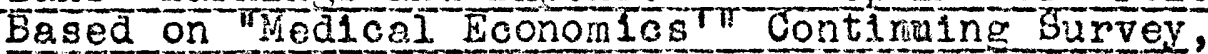
1960. OradeII, N. J.: Medical Éconemios, Ine., 1960.

Fiayack, Elton. Professional Power and American Medicine: The Economics of the American Medicar Association. Cleveland: The World Pubilshing Company, 1967.

"Results of Kedical Economics' First Annual Checkup of Physiclans Economic Health," Medical Economica, Nov. 2, 1964, pp. 61-107. 
Saward, M.D., Ernest W., Jenet D. Blank, and Merwyn R. Greenl1ck. "Documentation of Twenty Years of Operation and Growth of a Prepald Group Eractice PIan," Medical Care, VI (May-June, 1968), 231-44.

Smelser, Ne1l J. And Seymour Martin Lipset (eds.). "Sociel Structure, Mobility and Development, "Soclal Structure and Mobility in Economic Develooment, pp. $1-50$.

Čr1cago: hidine Publising Company, 1966.

Solomon, David N. "Ethric and Cless Differences among Hospitals as Contingencies in Medical cereers," AJS, LXVI $(1961), 463-71$.

U. S. Bureau of the Census. U.S. Census of the Populat1on, 1960 . Characterietics of the populetson. washington, D. O.: U. G. Government Printing Ofifice, 3.961.

Wheeler, Stenton. "The Structure of Formally Orgenized. Socialization Settings," Soclallzation after Child hood: Two Essays, Orvil G. Brira, Jr-and Stanton Wheeler, pp. 51-1i6. New Yorts: John Wiley \& Sons, Ine., 1966 .

Wliensky, Harold L. "Measures and Hfreots or Mobility," Sociel Styucture and Mob1lity in Econom ic Development, ed. NeIIJ. Smelser and Seymour Martin Lipset, pp. $98-$ 140. Chicago: Aldine Publishing Cordany, 1966.

Zeigel, Hans. Say It with Figures. 4th ex., rev. New York: Harper \& how, Hubishers, 1957. 


\section{APPENDIX A}

DATA ON JOB INQUIRIES AND JOB OPENIMGS IN KAISER

TABLE XXVII

DISTRIBUTION OF DISCONTINUED JOB INQUIRIES AND ADVERTISED JOB OPININGS IN KAISER OVER TINE

$$
\begin{array}{llllllllll}
1959 & 1960 & 1961 & 1962 & 1963 & 1964 & 1965 & 1966 & 1967 & 1968
\end{array}
$$

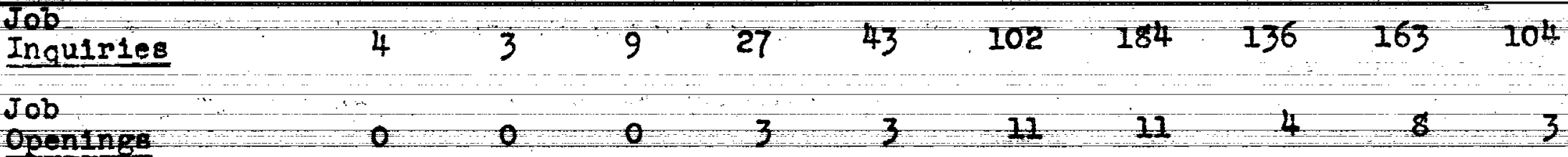

Source: The source of these date is Kalser's records of personnel advertisements and discontinued job inquiries. 
APPENDIX B

INCONE DETA.

I. INCOME ON SELECTED GROUPS OF PRIVATE PRACTITIONERS

TABLE XXVIII

MEDIAN NET INCOMES OF SELECTED GROUPS OF SELF-EMPLOYED PHYSICIANS UNDER

SIXTY-EIVE, 1959 AND 1963

Physiosan Group

Specialiats

Spocialists, under 10 Years or Practice

All Physicians

$$
\begin{array}{ll}
1252 & \text { Fhysician Groug } \\
\$ 24,800 & \begin{array}{l}
\text { Physicians, } \\
\text { under } 5 \text { Years or } \\
\text { Practice }
\end{array}
\end{array}
$$

$\$ 17.450$

Phy s1clans, 5-10 Years

22,300 of Practice

25,950

25,050

Source: The 1959 income data come from Phyelcians' Earnings and Expenses: A Reprint of Articlee Bged on Medical Econonics Continuing Survey, 1960 (Óradeli, N.J .: Medical Economics, Inc. 1960), po. 9, 10, 14. The 1963 data are from "Results of Medical Economles' Finst Annual. Checlrup of Physlcians' Economic Heal th, Medical Economics, November 2, 1964, pp. 104, 106. 
II. COMPARISON CF TWO SOURCES OF DATA ON KAISER

SALARIES AND TNFERENCES ABOUT MISSING

SALADY DATA

TABLE XXIX

LONGITUDINAL CONPARISON OF STARTING SALARIES

OF KAISER RADIOLOGISTS (R) AND ORTHOFEDIC

SURGEONS (ORS) AS REPORTED IN TWO

SOURCES OF DATA

Orficisl

Salary Schedule

Year

1951

1961

1963

1964

1965

1966

2967

1968

1969

R

$\$ 10,800$

20,000

21,200
Oris

$\$ 10,800$

18,000

$\$ 20,000$

24,000

24,000

$\$ 20,000$

24,000

24,000

30,000

30,000

30,000
Personnel Aã in

Medical Journels

ORS 
STARTING SALAETES OT KAISRR RADIOLOGISTS AND ORTHOPEDIC SURGEONS OVER IIRE BASED ON COMBIRATION OF DATA FROM OFFICIAL SALARY SCAEDULE AND RECOFDS OF PERSONNEL ADVERTISEMENTS

\section{Yeax}

1951

1961

1963

1964

1965

1966

1967

1968

1969
Starting Salarieo of $R$ and 0 R.

$\$ 10,800$

28,000

20,000

20,000

24,000

24,000

30,000

30,000

30,000

It 1 s assumed that these figures approximate the medien agarles of radiologists and oxthogadc eurgeons at Katser (seo the discugeton on pp. 45-46). The salaries of radiologlets and oxthopeds cureeons are close to those of the mceit highy paia specialists at Kaiser.

Source: Datia from en offlolal schedule of Kalser galaxios and roo records or personnel eavertisements wero compared ( Table $\times y x x$ ). Becalae of the many instances of Identical infonetion in the two gets of det a and because of the high degreo of conststency between them (there was only one al sarepeney), st aemed reasible to combine them. Thersby, mors comprehenaive salaxy data vere obtatned. Furtherrore, becaves of the high agreenent between the cohedules for sodologtsts end orthopedic zurgeone within both aets of atat, it seemed reaconable to assume that theee two specialises had iaentioal gelary schedules. Acoordingly, the data on those spectelties were also combined. 
III. ABSOLUTE COMPARISON OF INCOAES OF KAISER SPECIALISTS AND PRIVATE PRACTITIONERS

\section{TABLE XXYI}

LONGITUDINAL COMPARISON OF STARTING SALARIES OF ONE GROUP OF KAISER SPECIALISTS (IM-GS-OBG-PD) TO MEDIAN NET INCOHES OF SELE-EMPLOYED PHYSICIANS UNDER SIXTY-FIVE

$\begin{array}{lccc}\text { Year } & \begin{array}{c}\text { Starting Salary of } \\ \text { Kaiser Specialigt }\end{array} & \text { Yeara } & \begin{array}{c}\text { Incone or Seli- } \\ \text { Employed Physician }\end{array} \\ 1948 & \$ 8,400 & 1947 & \$ 8,744 \\ 1953 & 10,800 & 1951 & 13,150 \\ 1956 & 12,000 & 1955 & 16,01.7 \\ 1959 & 13,200 & 1959 & 22,100 \\ 1962 & 16,200 & 1962 & 24,300 \\ 1965 & 21,200 & 1964 & 28,380\end{array}$

aIt w1ll be noted that the years from which each set of income data come are not 1dentical. The years for which the Kalser data are reported were chosen not only to correspond to the data on self-erployed physicians but also to compensate for the Kalser pollcy of interspersing periodse large salary increasea vith periods of no salary increases.

bFor reasons explained in the text (pp. 45-47), these atarting salary figures for the IM-GS-OBG-PD group of Katser epecialists are interpreted to bo representative of the median starting salary of the Kalser phystcian.

Source: The Kalaer data came from an officlal schedule of starting salaries. The $1947-62$ data on self-employed physictans came from "Phy sicians" Economic Health," Medical Economies, Noverber 2, 1964 , pp. 64-65; the 1964 dat a came from eiton Rayack, Professtonal Power and Anerican Medicine: The Economics of the American Vedcel Association TCleveland: The forld publianing company, $196 \%, \mathrm{p}$. 110. 


\section{APPENDIX C \\ UNANTIGIPATED PROELEMS}

The main source of data on Kaiser physicians used in the present study was the application for staff membership, a standardized form filled out by all Kainer physlcians. It was chosen instead of physicians' curricula vitae on the assuription that it would provide more systemsttc and complete information on each physician than the curricula. However, as shom by the duta, this assumption vas false. In petrospect, It appears that the deosion to use the application forms as a source of data was not sound. 1

In the following discussion three problems which the use of the application forms rafsed will be described. Tho questions will be posed with reference to each problem: 1) Did it lead to systematic or random variation in the conpleteness of the data? 2) Did it lead to systematic or random errors in the data? In this way wo w11l assess the

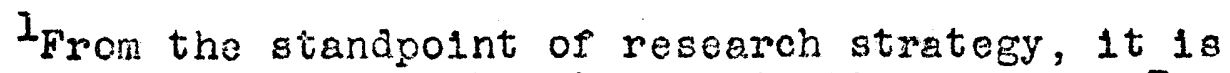
important to underetand how this situation arose. Two ractors seem primary: the researcher's lack of experience in working with different sources of data and the necessity of working through on intermediary in order to gain access to the data. As a result, the researcher never vent directly to the various soujces of data. Lacking the opportunity to determine the infornation in and the merits of each, the researcher never gained experience with the sources unt11. after the decision to use one of then had already been made. 
extent to which these problems affect the validity of the findings of the present study.

\section{FIRST PROBLEM}

The first problem which was discovered concerned the bureaucratic use of the application forms. The so-called "applications for staff membershlp" are not used as applications for active staff status in Kaiser, since the physiclens do not fill them out until after they have alroady assumed active staff status. Instead, the curricula vitae are used as application forms. During the time that pereonnel decisions are being made, the latter provide written information about the physicians. After the physiciens havo already become Kaleer staff menbers they fill out the "appl1cation for staff membership," which seems to represent a buxeaucratic procedure for information storgge and xetrieval.

The bureaucratic use of application forms for information storage and retrieval presented a problem for this study: It appeared that information was miseing from the forms as a result of the lise to which the forms were put. This became apparent from the instances when the curricula vitae were found with the application forns. In comparison to the application forms, the curricula provided more compiete and systematic information on the physicians. Thus, it appersed that the surricula, in eerving as applications, are fllled out with more care than the application forms, whose 
only purpose is record-keeping.

Unfortunately, it is not known whether this problem introduces systematic or random variation into the completeness of the data for this study, as in only a few instances was comparison of the application forms and current currioula vitae possible. No evidence of systematic variation was discovered in the course of data gathering. In other words, It did not appear that either the kind or the extent of information missing for each physicion was correlated with his status (rank) or with any other variable used in this study. However, the limlted evidence avallable allows no general conclusion about any variation which might have been introduced into the completeness of the data.

Nevertheless, it is likely that the use of the application forms as a source of data for this study introdiced coalne errors into the data. Comparison of the curricula vitae to the application forms showed that interpretations of the data which were based on both these sources of data vere different from those based on only a single source. However, since the curricula vitee were generally unavollable, it was lmpossible to compare the curriculum of each physician to his epplication form in order to ellminate the coding exrors which would result from the use of the application forms alone as a source of data. Consequently, the use of the application forms as a source of dats probably lea to errors in the deta of this stuay. 
Since it is not known whether cases of missing information are randomily or systematically distributed within the universe of Kalser physicians, it is also unknown whether the coding errors which result from the missing inforination are randomly or systematically distributed within the universe. Therefore, there is no way to assess the degree to which the validity of the results of this study is af pected by the problems of miselng information which arise from the bureaucratic use of the application forms.

\section{SECOND PROBLEM}

The second problem which was discovered involved bureaucratic changes in the format of the application forms. The varlovis forms whlch vere used over the years call for different types and anounts of information on each physic1an. 2 As a result, some 1tems of information are missing for physiclans who filled out sertain types of application forms.

The earliest source of information discovered for any physician was not even a form but merely a typed sheet of information covering training, professionel societies, and certifleation. The first application form asked for tratning, practice, cortiflcaition, and military service. Nelther of these two eources of data were dated.

Over the years, two other application forms were usea, each of vinich asked for the same kinds of information. One was put intc use about 1955 and seems to have been filied out annual. y until 1959. In that year the Bess Kadser Hospltal in Portlana wes opened to replace the Vancouver, Washington hospltal, and the application fom which is in current use was introduced. The staff who transferred from Vancouver to Portiand filled tt out one. After 1959, new staff aleo c1lled it out only crice upon entry into kaisor. 
The problem of bureaucratic changes in the format of the application forms clearly. Introduced a systematic bias Into the completeness of the data for this study. Comparison of the information in the most recently introduced forms (1959) revesls that physiclens who entered Kais 8r after 1959 filled them out much more completely than phys1clans who entered Kalser beforo 1959 and who fllled out the Forms in 1959 upon transfer to the Bess Kalser Hospital in Portland from the hospital in Vancouver. With regard to the forms used before the current type of application form was Instituted (1.e., before 1955), the more recent forms contain mose information than the older forms; furthermore, all these forms contain less information than the current type of form.

These comparisons show that the earlier a physician entered Kolser, the higher the probability that data on him are not complete. In other words, the completeness of the data on any physician varjes accoraing to the time he entered Kalser. Since bcth the status of Kalser and the status of 1ts recrults also vary over time, it $1 \mathrm{~s}$ likely that these variations in the completeness of the data on physicians aro systeratically correlated with either the status of Kaiser or the status of its recrults, or both. Thus, it is clear that bureaucrat1c changes in the format of the application forns introauced a systatic bias into the completeness of the date for the present study. 
However, it is unlikely that this bias in the cornpleteness of the data led to systemat1o coding errors. Since all the application forns which had been used over the years were avallable, the vardety of forms whlch had frequently been filled out by a given physician could be compared. Instances of information misaing on any given form could be identifled and thus many potential coding errors avolded. ${ }^{3}$

For example, the 1959 application form of physiclans who entered Ka1ser between 1955 and 1959 was compared to the form which was used between 1955 and 1959. Although the 1959 form was generally inoomplete, it was usually posstble to find a complete form by locaing the first form which had been fliled out by these physicians. Similarly, several forms could be compared for physicians who left Kaiser between 1952 and 1955. Thus, the inadequacy of any partioular form could be compensatea for to some extent.

Although these comparisons eliminated many potential coding errors, some errors probably coula not be avolded. The information calied for on both forms which were used prior to 195518 less extensive than that on the forms used after 1955. Therefore, the information on physicians who

\section{Actually, the necessity for conparing and making} inferenoes from dirferent forms may have lea to some coding exrors. The complexity and length of some of the physicians' careers plus the great amount of information to be compared before inferences could be made inevitably resulted in some errors. 
Ellled out the former form 18 probably less complete than the information on physiclens who filled out the latter forms. In sum, bureaucratic changes in the format of the application forms have probably led to a slight systematio bias in the completeness of the data for this study.

\section{THIRD PROBLEM}

The third probler which was discovered involved the missing personnel records of the ten physialans who lert Kaiser before 1952. 4 As a result of this problem, the present stuay contains almost no data on these physicians.

These missing personnel records systematically bias the completeness of the dota for this study. All the missing records come from the period 1943 to 1953 when Keiser had low status. In other woras, the missing records aro correlated with the status of Kalser. As a result, the conpleteness of the date for this study is aystematically biased.

4 Although 1t is possible that records were not kept auring the flrst years of Kaiser's operation, there $1 \mathrm{~s}$ evidance which indicates thet recores were kept and that the records on the physicians who left Kalser beforo 1952 disappeared. Firat, complete information, incluaing curricula vitae, letters of reference, and various early application forms, was found for one physiclan who applied to and entered Kaiser eround the end of 1945. This suggest written records of some kind were kept even on the earliest Kalser physicians. Second, an informant reported that many years ago all the records on the Kalser starf disappeared and that later only those of the active staff reappeared. The records of physiciens who became inactive prior to 1952 weve m1so1ng. 
The only readily avaliable alternative source of data on these physicians, the American Medical Directory, contained only one 1tea of rejevant information on each physiclan, namely, his medical schooj. Consequently, there was no way to compensate for the lack of data on these phys1clans in the Kalser personnei rocords. Therefore, many or our conclusions concerning phyglclans who entered Kalser between 1943 and 1953 may be in error.

\section{CONCLUSION}

The three problems whlch vere ralsed by the use of the staf application as a source of data for this study have now been described in full. With regard to the f1rst problem, which concerned the bureaucratic use of the application forms, it was not possible to determine aefinitely l) whether 1t had led to systematic or random variation in the completeness of the data and 2) whether it had led to systematic or random errors in the coding of the data.

In contrast, it was clear that the second and third problems, which involved bureaucratic changes in the format of the forms and ten missing personnel records, had produced systematic varlation in the completeness of the data. However, only the miselng personnel records may have led to errors in the data. In particular, some of our conclusions concerning the physiclans who entered Ka1ser from 1943 to 1953 may be false. We conclude that the validity of some of 
the results of this study is questionable.

As a result of our discovery that the application forms did not provide systematic and complete information on each Kalser physictan, the sounaness of the decision to use these forms as a source of dats for this study must be questioned. If the present study could be done over again, the starf applications would not be chosen as the sole source of data. Rather, multiple sources of data, e.g., the application forms as well as curricula vitae, letters of reference, etc., would be used. The disadvantages of any particular source of data could then be identified and dealt with. 
Typed by

Frances T. Hall 